\title{
Where Did Mill Go Wrong?: Why the Capital- Managed Firm Rather than the Labor-Managed Enterprise Is the Predominant Organizational Form in Market Economies
}

\author{
JUSTIN SCHWARTZ*
}

\begin{abstract}
In this Article, I propose a novel law and economics explanation of a deeply puzzling aspect of business organization in market economies. Why are virtually all firms organized as capital-managed and -owned (capitalist) enterprises rather than as labor-managed and -owned cooperatives? Over 150 years ago, J.S. Mill predicted that efficiency and other advantages would eventually make worker cooperatives predominant over capitalist firms. Mill was right about the advantages but wrong about the results. The standard explanation is that capitalist enterprise is more efficient. Empirical research, however, overwhelmingly contradicts this. But employees almost never even attempt to organize worker cooperatives. I critique the explanations of the three leading analysts of the subject (N. Scott Arnold, Henry Hansmann, and Gregory Dow), all of whom offer different transactions cost accounts as logically defective and empirically inadequate. I then propose an explanation that has been oddly neglected in the literature, that the rarity of cooperatives is explained by the collective action problem identified by writers such as Mancur Olson. Labor management is a public good that generates the $n$ person prisoner's dilemma that gives rational actors the incentive to create it in suboptimal (or no) amounts. I support this by reference to the empirical facts about the origin of existing cooperatives and show that this explanation requires no strong version of a questionable rational choice theory. My account points advocates of labor management towards solutions such as institutional changes in incentives, which, however, themselves involve public goods issues.
\end{abstract}

TABLE OF CONTENTS

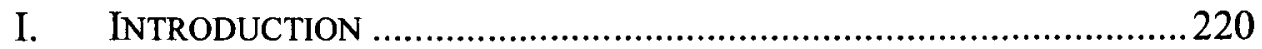

II. "THE PROBABLE FUTURITY OF THE LABOURING ClASSES":

PROGNOSTICATION AND REALITY ..............................................225

*Assistant Professor of Law, The John Marshall Law School, Chicago, IL; J.D., Moritz College of Law, The Ohio State University; Ph.D, M.A., The University of Michigan; M.Phil., The University of Cambridge; A.B., Princeton University; email: jkschw1@gmail.com. Thanks are due to David Schweickart for fruitful discussion and constant inspiration, to N. Scott Arnold for generous detailed written comments and constructive provocation, to Elizabeth Anderson, Robert and Betsy Bowman, Anthony Cooper, William Ford, Peter King, Richard A. Posner, Joel Rogers, Tony Smith, Nina Strohminger, Frank Thompson, and Chris Yonashonais, my research assistant on a very early iteration of this Article, as well as to participants in various presentations of distant ancestors of this paper. 
A. Mill Versus Marx on the Future of Labor Management in Market Economies ............................................................2225

B. The Rarity of Labor Management ......................................2229

1. Where Mill Was Right ...................................................2229

2. Where Mill Was Mistaken............................................. 233

III. THREE TRANSACTIONS COST EXPLANATIONS ..............................240

A. The Evolutionary Hypothesis, the Coasean Background, and Transactions Cost Analysis......................................... 240

B. Transactions Costs Internal to the Enterprise ...................... 242

1. Arnold: The Fear of the Monitor Is the Beginning of Efficiency ................................................................ 242

2. Hansmann: Homogeneity and the Costs of Collective Decision Making ........................................................... 251

C. Transactions Costs External to the Enterprise: Dow's Capital Formation Problem............................................... 257

1. Issues of Outside Financing........................................ 257

2. The Reality of Self Financing....................................... 263

IV. Where Mill Went Wrong: A Public Goods/Collective ACTION ACCOUNT ................................................................ 267

A. Public Goods and Collective Action-The Theoretical Framework

B. The Theory Applied to the Formation of the LaborManaged Firm

C. Collective Action Problems Without Taking Rational Choice Theory Too Far

V. CONCLUSION 281

\section{INTRODUCTION}

As Paul Samuelson pointed out, in a perfectly competitive market, it makes no difference whether capital hires labor or labor hires capital. ${ }^{1}$ Why, then, is the predominant form of industrial organization in market societies the traditional capital-owned and capital-managed firm (the capitalist firm) ${ }^{2}$ rather

${ }^{1}$ Paul Samuelson, Wages and Interest: A Modern Dissection of Marxian Economic Models, 47 AM. ECON. REV. 884, 894 (1957) ("[I]n a perfectly competitive market it really doesn't matter who hires whom: so have labor hire 'capital' . . ...").

2 It will become important at several points to distinguish between types of capitalist firms, see infra notes 126-53, 180-189, and 220-231 and accompanying text, including, notably, the classic capitalist firm, often entrepreneurial, with a small ownership group or single owner closely involved in actual management, see Armen A. Alchian \& Harold Demsetz, Production, Information Costs and Economic Organization, 62 AM. ECON. REV. 777, 781-83 (1972), reprinted in ARMEN A. ALCHIAN, ECONOMIC FORCES AT WORK 73, 8386 (1977) [hereinafter ALCHIAN, ECONOMIC FORCES], and the open corporation, owned often 
than the labor-managed enterprise owned and managed by the workers (the cooperative) $?^{3}$ This is exactly the opposite of the result predicted by John Stuart Mill over 150 years ago. He thought that such worker-run cooperative associations would eventually crowd capitalist firms out of the market because of their superior efficiency and other advantages for workers. ${ }^{4}$ What we see in reality is that capitalist firms, both entrepreneurial and corporate, are utterly predominant. Cooperatives barely exist. The idea of a labor-managed economy 5 of the sort envisaged by Mill seems fantastically utopian. Is there any compelling reason that modern firms should take the forms that they do and that the economy should be structured along the lines we observe? Actual markets

by thousands of investors represented by a board of directors and managed by professional managerial employees, see Eugene F. Fama \& Michael C. Jensen, Agency Problems and Residual Claims, 26 J.L. \& ECON. 327, 328-32 (1983) [hereinafter Fama \& Jensen, Agency Problems]; Eugene F. Fama \& Michael C. Jensen, Separation of Ownership and Control, 26 J.L. \& ECON. 301, 312-15 (1983) [hereinafter Fama \& Jensen, Separation of Ownership]. In addition, there is the traditional capitalist firm (my term), hierarchically organized and managed, which may be classic or corporate, as well as the more or less participatory capitalist firm, in which the employees participate to some extent in management decisions. There are also more or less employee-owned capitalist firms, such as ESOPs, see infra note 58 , almost all corporate in form, which may be more or less participatory.

In a companion piece to this Article, Justin Schwartz, Voice Without Say: Why More Capitalist Firms Are Not (Genuinely) Participatory, 17 FORDHAM J. CORP. \& FIN. L. (forthcoming 2012), I address why capital-managed firms, both classic capitalist enterprises and corporations, tend not to institutionalize genuine worker participation. When I write about the "capitalist firm" or the "capital-managed firm," I include all forms of capitalist enterprises that are not cooperatives, that is, managed and owned by the workers. All these terms are to some extent matters of degree and debates can arise about particular cases. See, e.g., infra notes 181-186 and accompanying text (discussing the attempt of HENRY HANSMANN, THE OWNERSHIP OF ENTERPRISE (1996) [hereinafter HANSMANN, ENTERPRISE], to disregard or diminish the labor-managed status of the Mondragón cooperatives, perhaps the best known and most successful complex of cooperative productive enterprises in the world, see infra notes 74-82 and accompanying text).

${ }^{3}$ I am concerned here with labor-managed and -owned enterprises operated and owned by employees and devoted primarily to productive, broadly manufacturing, economic activity rather than with agricultural, consumer, or service cooperatives, which are somewhat more common. See, e.g., HANSMANN, ENTERPRISE, supra note 2, passim (surveying the range and distribution of cooperative enterprise). The former are the sort that have been the focus of most discussion about worker control.

4 John Stuart Mill, Principles of Political Economy with Some of Their Applications to Social Philosophy 752 (W.J. Ashley ed., Longmans, Green \& Co. 9th ed. new ed. reprt. 1915) (1848). Mill's case is summarized infra Part II.

${ }^{5}$ See generally JAROSLAV VANEK, THE LABOR-MANAGED ECONOMY (1977). Vanek, unlike Mill, considers the optimal form of ownership of an economy dominated by labormanaged firms to be social rather than private ownership by the workers in the firm. See id. at $180-81$. In this respect, Vanek is closer to the model proposed by David Schweickart. See generally DAVID SCHWEICKART, AGAINST CAPITALISM (1993) [hereinafter SCHWEICKART, AGAINST] (setting forth perhaps the best recent self-identified socialist defense of economic democracy based around labor-managed forms); DAVID SCHWEICKART, AFTER CAPITALISM (2002) [hereinafter SCHWEICKART, AFTER] (sequel to Against Capitalism). 
are not perfectly competitive, ${ }^{6}$ but that is hardly an explanation without specifying what creates the overwhelming asymmetry in favor of traditional capitalist firms with little or no genuine worker participation. The usual explanation is that Mill was wrong about the efficiency advantages of the labormanaged firm over its capitalist competitors.

But Mill was not wrong on that point. The literature shows that participatory organization, even in capitalist firms, has significant productivity advantages over traditional hierarchical capitalist management, and the comparisons favor more fully labor-managed and labor-owned firms just as strongly and perhaps more so. In this Article, I address the deep puzzle about why these organizational features are uncommon in productive enterprise. In particular, I consider why workers so infrequently even attempt to create their own firms, managed and owned by themselves, embodying these competitive advantages. After critiquing the main standard explanations, I offer a novel explanation that is barely mentioned, much less explored, in the voluminous literature on the subject. The core of the theory is that labor management is a public good, the creation of which is impeded by the usual obstacles to collective action, in addition to the self-perpetrating effect of its unfamiliarity due to its rarity.

There are other efficiency-related points of comparison and contrast between the two broad types of enterprise organization: for example, why far more existing labor-managed firms convert to capital-managed firms than vice versa $^{7}$ and whether and how the differing organizational incentives might create differential performance or behavior between them, ${ }^{8}$ perhaps to the

${ }^{6}$ See, e.g., Steven Walt, The Relation Between Competition and Cooperation, 15 HARV. J.L. \& PUB. POL'Y 733, 736-37 (1992). A standard explanation of perfect competition is as follows:

Perfect competition refers to the type of market organization in which (1) there are many buyers and sellers of a commodity, each too small to affect the price of the commodity; (2) the commodity is homogeneous; (3) there is perfect mobility of resources; and (4) economic agents have perfect knowledge of market conditions (i.e., prices and costs).

Dominick Salvatore, Microeconomics: Theory and Applications 262-63 (5th ed. 2009). Apart from isolated outposts that may approximate these conditions, or some of them, none of these conditions obtain in actual markets. The classic work on the subject is JOAN ROBINSON, THE ECONOMICS OF IMPERFECT COMPETITION (1933). See also, e.g., FRIEDRICH A. HAYEK, The Meaning of Competition, in INDIVIDUALISM AND ECONOMIC ORDER 92 (1948). For the classic mathematical discussion of the perfectly competitive market, see Kenneth J. Arrow \& Gerard Debreu, Existence of an Equilibrium for a Competitive Economy, 22 ECONOMETRICA 265 (1954) (discussed infra notes 296-299).

7 See, e.g., GREGORY K. DOW, GOVERNING THE FIRM: WORKERS' CONTROL IN THEORY AND PRACTICE 43 (2003); HANSMANN, ENTERPRISE, supra note 2, at 46, 80-86; N. Scott Amold, Further Thoughts on the Degeneration of Market Socialism: A Reply to Schweickart, 3 ECON. \& PHIL. 320 (1987).

${ }^{8}$ Thus, Benjamin Ward famously argued in neoclassical terms that the "Illyrian" firm-Illyria is the Latin name for the area occupied in part by the former Yugoslavia, 
disadvantage of the labor-managed firm. However, these matters, while important in thinking about the design of a labor-managed firm or labormanaged economy and to comparisons between existing cooperatives or capitalist firms, do not go to the fundamental issue I discuss here: why so few labor-managed firms are formed at all. Any possible inefficiencies of an organizational form will not be tested in the crucible of the market if that form is not tried in numbers great enough to allow assessment of whether those inefficiencies are real and significant enough to explain its comparative rarity. Such inefficiency explanations would be more plausible if many were called (created) but few were chosen (selected by the market to survive over alternative forms).$^{9}$ If, as is the case, almost none are called, that is where inquiry should begin.

In Part II, I set the stage by contrasting Mill's optimistic predictions for the prospects of labor management in a market economy with the skepticism about this form of organization expressed by his contemporary Karl Marx. I confront Mill's hopes with the disappointing empirical facts about the extreme rarity of the labor-managed firm that, during the subsequent century and a half, has seemed at least on this point to vindicate Marx and rebuke Mill. In Part III, I take up the obvious explanation that labor management and ownership are rare because, pace Mill, these organizational forms are economically or otherwise inefficient. To keep the discussion manageable, I consider only the three candidate explanations that seem to me the strongest or at least the most influential. The ones I consider derive from what is called transactions cost analysis, broadly economic analyses that turn on the idea that the "friction" involved in coordinating interactions within or among institutions, ${ }^{10}$ the costs of which play an essential role in explaining outcomes through a quasi-Darwinian

which, during much of its existence, organized its economy around a form of worker selfmanagement, see infra note 16-will exhibit some perverse incentives, e.g., reducing output in response to an increase in demand, see BENJAMIN N. WARD, THE SOCIALIST ECONOMY: A STUDY OF ORGANIZATIONAL ALTERNATIVES 209 (1967), or maintaining operations even at a loss if the workers will take a pay cut and overinvesting in capital as opposed to labor to avoid dividing profits among more workers, leading to what might be a suboptimal use of resources, $i d$. at 210 . I discuss problems somewhat similar to these that have been raised for existing labor-managed firms in this Article, and contend that they are not responsive to the question I address, which is why so few such firms are even started.

${ }^{9}$ See Matthew 22:14 (King James) ("[M]any are called, but few are chosen."); see also Armen E. Alchian, Uncertainty, Evolution, and Economic Theory, 58 J. PoL. ECON. 211, 220 (1950), reprinted in ALCHIAN, ECONOMIC FORCES, supra note 2, at 15, 32 (stating that the comparative efficiency of different "patterns of behavior and organization are predictable ... if they are tried").

${ }^{10}$ See generally OLIVER E. WILlLIAMSON, THE ECONOMIC InSTITUTIONS OF CAPITALISM: FIRMS, MARKETS, RELATIONAL CONTRACTING (1985) [hereinafter Williamson, INSTITUTIONS] (setting forth the most comprehensive modern survey of this approach); Oliver E. Williamson, The Organization of Work: A Comparative Institutional Assessment, 1 J. ECON. BEHAV. \& ORG. 5 (1980) (providing more specific analysis in a case study). For a summary, see Steven N.S. Cheung, Economic Organization and Transaction Costs, in 2 THE NEW PALGRAVE: A DiCTIONARY OF ECONOMICS 55, 55-58 (John Eatwell et al. eds., 1987). 
process of selection for most efficient, least-cost features, including organizational form (Part III.A).

Two of the three explanations I critique attempt to account for the greater purported inefficiency of cooperative as opposed to capitalist firms by reference to features of their respective internal operations (Part III.B), specifically: (1) the comparative costs of monitoring to avoid shirking and opportunistic employee behavior in firm management and supervision (Arnold ${ }^{11}$ ), and (2) the higher costs of issues of collective decision making among heterogeneous individuals (Hansmann ${ }^{12}$ ). These explanations involve logical difficulties, and ultimately founder on the well-substantiated fact that Mill was right that labor management is more productive than capital management. The last explanation I take up (Part III.C) is that workers so rarely start up cooperatives because of the difficulties of generating enough capital (Dow $\left.{ }^{13}\right)$. This explanation involves inefficiencies regarding the comparative cost of the interactions of the capitalist and cooperative enterprises with the external market environment, specifically the credit market. Dow's version of this explanation avoids the worst pitfalls besetting Arnold's or Hansmann's, but it too is deeply problematic from the point of view of economic logic and empirical fact.

In Part IV, I present my own proposed explanation, that the rarity of the labor-managed firm in market economies is primarily due to the sort of collective action problem involved in coordinating the behavior of multiple actors most famously expounded by Mancur Olson in his theory of public goods, ${ }^{14}$ namely that collective action to achieve a common interest will produce suboptimal (or no) results if the good is one from which all benefit regardless of the contribution of any. In addition, there is the consequent and related problem of lack of models to imitate and inspire due in large part to the very lack of familiarity with labor management precisely because of its rarity. ${ }^{15}$ Mill went wrong largely by overlooking the public goods problem as an objection to his prognostication. The top-down, deductive nature of this sort of explanation omits important historical and psycho-sociological explanatory

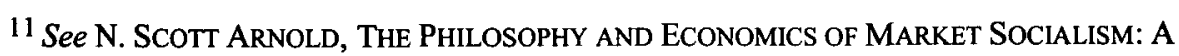
CRITICAL STUDY 1-49 (1994) [hereinafter ARNOLD, PHILOSOPHY AND ECONOMICS] (presenting an excellent quasi-libertarian critique of Schweickart-style market socialism); $\mathrm{N}$. Scott Amold, Market Socialism, 6 CRITICAL REV. 517, 534-36 (1992) [hereinafter Arnold, Market Socialism].

12 See HANSMANN, ENTERPRISE, supra note 2, at 89-98.

13 See Dow, supra note 7, at 236-38.

14 See generally Russell HaRdin, Collective ACtion (1982); MANCur Olson, The LOGIC OF COLLECTIVE ACTION: PUBLIC GOODS AND THE THEORY OF GROUPS (2d prtg. 1971). Mill, curiously, saw the public goods problem clearly in a different context, viz., the need for legal rather than voluntarily adopted limits on the working day, see MILL, supra note 4 , at 963-64, but he failed to apply the insight to his prediction about the eventual triumph of the cooperative, see infra notes 243-245 and accompanying text.

${ }^{15}$ See generally, e.g., Robert F. Bornstein, Exposure and Affect: Overview and MetaAnalysis of Research, 1968-1987, 106 PSYCHOL. BULL. 265 (1989) (reviewing studies of the "mere exposure effect"); infra note 226. 
information, but if an empirically richer account were articulated, I believe it would complement the public goods explanation. The familiarity or mere exposure effect I invoke to supplement this account suggests as much. In my Conclusion, I argue that overcoming the collective action problem for labor management requires, at a minimum, appropriate extra-market (e.g., governmental) action to change the incentive structures, but this poses new sets of public goods problems of its own.

\section{II. "The Probable Futurity of the Labouring ClasseS": PROGNOSTICATION AND REALITY}

\section{A. Mill Versus Marx on the Future of Labor Management in Market Economies}

The overwhelming asymmetry between the capital-managed and labormanaged firm has seemed so much like an inevitable "natural" fact as to rarely rise to consciousness. At times of social uncertainty, such as the decline and collapse of Soviet-style Communism, the issue surfaces again. ${ }^{16}$ It is useful

${ }^{16}$ The issue of an economy organized around labor-managed firms enjoyed a fruitful renaissance in this period: important works include, notably, Henry Hansmann, When Does Worker Ownership Work? ESOPs, Law Firms, Codetermination, and Economic Democracy, 99 Y ALE L.J. 1749 (1990) [hereinafter Hansmann, Worker Ownership]; its indispensable book-length successor, HANSMANN, ENTERPRISE, supra note 2; ARNOLD, PHILOSOPHY AND ECONOMICS, supra note 11; THEODORE A. BURCZAK, SOCIALISM AFTER HAYEK (2006); Dow, supra note 7; DAVID P. ElLERMAN, THE DEMOCRATIC WORKER-OWNED FIRM: A NEW MODEl FOR THE EAST AND WeST (1990); MARKETS AND DEMOCRACY: PARTICIPATION, ACCOUNTABILITY AND EFFICIENCY (Samuel Bowles et al. eds., 1993); AlEC Nove, The ECONOMICS OF FEASIBLE SOCIALISM REVISITED (2d ed. 1991); SCHWEICKART, AGaINST; supra note 5; SCHWEICKART, AFTER, supra note 5; and Arnold, Market Socialism, supra note 11. These studies are merely a few of the many that sprang up between the crises that led to the Soviet experiment in Perestroika and their aftermath, mostly before it became clear that post-Soviet Russia would become a mere autocratic kleptocracy. See, e.g., DAVID E. Hoffman, The Oligarchs: Wealth ANd Power IN THE New Russia (2002); Peter REDDAWAY \& DMITRI GLINSKI, THE TRAGEDY OF RUSSIA'S REFORMS: MARKET BOLSHEVISM AgAINST DEMOCRACY (2001).

Prior experiments in labor-managed firms and economies had attracted a steady but lower-intensity degree of scholarly attention, particularly with the former Yugoslavia, see, e.g., Branko Horvat, The Political Economy of Socialism: A MarXist Social THEORY (1982) (Although Marx would have emphatically rejected the claim that a market society of any sort could be "Marxist," if he had used the term "Marxist."); VANEK, supra note 5; JAROSLAV VANEK, THE PARTICIPATORY ECONOMY: AN EVOLUTIONARY HYPOTHESIS AND A STRATEGY FOR DEVELOPMENT (1971), and the Mondragón collectives in Spain, see, e.g., HENK ThOMAS \& Chris logan, MONDRAgON: AN ECONOMIC ANALYSIS (1982); William FoOTE Whyte \& KathleEN KING Whyte, MaKING MondRaGON: THE GROWTH AND DYNAMICS OF THE WORKER COOPERATIVE COMPLEX (1988); discussion infra note 74, as well as the Israeli kibbutz, see, e.g., DANIEL GAVRON, THE KIBBUTZ: AWAKENING FROM UTOPIA (2000); MELFORD E. SPIRO, KIBBUTZ: VENTURE IN UTOPIA (new, augmented ed. 
from the point of historical perspective to briefly step back to a previous period of upheaval, and consider the reflections of John Stuart Mill on "The Probable Futurity of the Labouring Classes,"17 in light, even more briefly, of Marx's highly critical appraisal of cooperatives. It is unnecessary for my purposes to put ideologically loaded labels on an economic model in which the labormanaged firm predominates. For my purposes, red-flag terms like "socialism,"18 or, for that matter "capitalism," are misleading. I here avoid

1970). This only scratches the surface, but the clustering of the dates from the early 1980 s to the early 2000 s is significant.

In addition, there is a large amount of literature on the labor-managed firm in the United States, much of which is surveyed in Hansmann, Worker Ownership, supra; HANSMANN, ENTERPRISE, supra note 2; SCHWEICKART, AGAINST, supra note 5; and SCHWEICKART, AFTER, supra note 5, as well as, inter alia, ELLERMAN, supra, and Dow, supra note 7. 1 discuss the main factual conclusions, on which there is perhaps surprising agreement, unlike the explanations for those facts. See discussion infra Part II.B.1-2. I also address far more briefly the ESOP-a more or less employee-owned but typically not labor-managed firm. I do not consider models of a market economy organized around public ownership without labor management. See generally JOHN E. ROEMER, A FUTURE FOR SOCIALISM (1994).

${ }^{17}$ MILL, supra note 4 , at 752 (bk. IV, ch. VII, written for the first edition in the revolutionary year 1848).

${ }^{18}$ The idea of the labor-managed firm, or even a labor-managed (market) economy, is not intrinsically socialist, certainly not if socialism involves the abolition of markets or of private property in productive assets. See KARL MARX \& FREDERICK ENGELS, MANIFESTO OF THE COMMUNIST PARTY (1848) [hereinafter MARX, MANIFESTO], reprinted in THE MARXEngels Reader 469, 484 (Robert C. Tucker ed., W.W. Norton \& Co. 2d ed. 1978) [hereinafter MARX-ENGELS READER] ("[T]he theory of the Communists may be summed up in the single sentence: Abolition of private property."). Nonetheless, labor self-management has had considerable appeal for socialists as the bloom has faded from the Soviet model of central planning. See, e.g., Diane Elson, The Economics of a Socialized Market, in AFTER THE FALL: THE FAILURE OF COMMUNISM AND THE FUTURE OF SOCIALISM 310, 310-14 (Robin Blackburn ed., 1991); see also sources cited supra note 5 (exemplary of a socialist turn towards labor management). For decidedly anti-socialist and highly critical analyses of labor management in a socialist context, see, for example, ARNOLD, PHILOSOPHY AND ECONOMICS, supra note 11, JÁnOS Kornai, The Socialist System: THE POlITICAL ECONOMY of COMMUNISM 461-512 (1992), and Arnold, Market Socialism, supra note 11.

Many socialists and others would emphatically reject the idea that a market economy, labor-managed or otherwise, could be socialist. See KARL MARX, CRITIQUE OF THE GOTHA PROGRAM (1891), reprinted in MARX-ENGELS READER, supra, at 529 ("Within the cooperative society based on common ownership ... the producers do not exchange their products ...."). Such writers would concur with the characterization of a labor-managed firm or even a market economy primarily composed of such firms as "capitalism without capitalists." See, e.g., Peter F. DruCKer, Post-CaPITAlist SOCIETY 74 (1993); 3 KarL MARX, CAPITAl: A CRITIQUe of Political ECONOMY 571 (David Fembach trans., Penguin Classics 1991) (1894) [hereinafter 3 MARX, CAPITAL] (stating that in a market system, workers in labor-managed cooperatives "become their own capitalist[s]"). See generally KeIth Bradley \& Alan Gelb, Worker Capitalism: The New Industrial Relations (1983); Market Socialism: The Debate Among Socialists (Bertell Ollman ed., 1998) (containing essays by self-identified socialists on both sides debating whether market socialism is socialism). 
terminological debates to concentrate instead on explanatory questions. I take no position on questions of public versus private cooperative ownership in this Article. Like Mill, I assume that the firms, the organization of which is at issue, operate in more or less competitive market economy. A market economy of the sort Mill envisaged in which the labor-managed firm is the predominant organizational form I call a labor-managed economy. ${ }^{19}$

Writing in the aftermath of the Revolutions of $1848,{ }^{20}$ John Stuart Mill predicted that in the long run the capital-managed firm ${ }^{21}$ would be superseded by the labor-managed firm:

The form of association, however, which if mankind continue to improve, must be expected in the end to predominate, is not that which can exist between a capitalist as chief, and workpeople without a voice in the management, but the association of the labourers themselves on terms of equality, collectively owning the capital with which they carry on their operations, and working under managers elected and removable by themselves. ${ }^{22}$

"[C]onfining ourselves to economical considerations," Mill wrote, "I cannot think that [the working classes] will be permanently contented with the condition of labouring for wages as their ultimate state." 23 Mill anticipated that "the relation of masters and workpeople will be gradually superseded by partnership.... in some cases... and perhaps finally in all, association of

${ }^{19}$ See generally VANEK, supra note 5.

${ }^{20}$ Mill expressly tied the possibility of realizing the labor-managed firm on a large and growing scale, as opposed to merely theorizing about it, to the French Revolution of 1848. See MILL, supra note 4, at 773. This was the same upheaval in which Marx wrote the Communist Manifesto.

21 Hansmann calls this the "investor-owned firm," HANSMANN, ENTERPRISE, supra note 2 , at 53 , but this seems to me potentially misleading because, at least in the modern corporation that dominates the economic landscape, the division of ownership and control has the result that ordinary investors have little or no say in firm management, see ADOLF A. Berle, Jr. \& Gardiner C. MEans, The Modern Corporation and Private Property 6, 346 47 (1932); EDWARD S. HERMAN, CORPORATE CONTROL, CORPORATE POWER 6-7, 257 (1982) (discussing BERLE \& MEANS, supra); Stephen M. Bainbridge, The Case for Limited Shareholder Voting Rights, 53 UCLA L. REV. 601, 603 (2006) (underlining the lack of influence of an ordinary shareholder on corporate policy); see also discussion infra notes 133-134 and accompanying text. Dow's term, "capital-managed firm," see Dow, supra note 7 , at 5-7, 10-12, seems more exact.

${ }^{22}$ MILL, supra note 4, at 772-73. The concept is protean, having no single agreed-upon form, see Dow, supra note 7, at 256 (arguing that "workers' control" is not a "unitary phenomenon"), as will be indicated below in brief discussions of some specific examples, such as the plywood cooperatives or Mondragón. See, e.g., infra note 44 and accompanying text. It is sometimes also called "self-management," "worker management," "participatory management," or "cooperation." Marx and Mill call it "association." See 3 MARX, CAPITAL, supra note 18, at 959; MILL, supra note 4, at 763.

${ }^{23}$ MILL, supra note 4, at 760. 
labourers among themselves." 24 Mill, like Marx, thought that democratic worker management would in the long run work better than management by capitalists or their agents. For Mill, among the main advantages of "association" were that it (1) promoted self-realization through meaningful work, converting "each human being's daily occupation into a school of the social sympathies and the practical intelligence"; 25 (2) would be more efficient and productive because it would give workers an interest in "do[ing] the utmost, instead of the least possible, in exchange for their remuneration," 26 since discipline would be "self-imposed, for the manifest good of the community, and not for the convenience of an employer ... having an opposite interest"; 27 and (3) it would "enable [human beings] to work with or for one another in relations not involving dependence," 28 promoting what we today call democracy, both in the political sphere and the organization of enterprise affairs. "[T] hey will require that their conduct and condition shall be essentially self-governed."29

Mill, however, unlike Marx, "utterly dissent[ed] from.... [socialists'] declamations against competition." 30 Mill's "associations" would produce forprofit and trade in markets. Also unlike Marx, Mill thought that a transition to a labor-managed economy could occur "without violence or spoliation, or even

${ }^{24} I d$. at 764 (footnote omitted).

${ }^{25} \mathrm{Id}$. at 790 . This is one of Marx's main themes. Work, he thought, "develops the potentialities slumbering within nature, and subjects the play of its forces to [man's] own sovereign power." 1 KARL MARX, CAPITAL: A CRITIQUE OF POLITICAL ECONOMY 283 (Ben Fowkes trans., Penguin Classics 1990) (1867) [hereinafter 1 MARX, CAPITAL]. But work under capital, with "the undisputed authority of the capitalist over men, who are merely members of a total mechanism, which belongs to him," id. at 477 , leads, Marx said, to "physical and mental degradation, ... premature death, [and] the torture of over-work," id. at 381. (Neutrality of tone is not in Marx's stylistic repertoire.) In contrast, in the sort of (nonmarket) cooperative production Marx envisages under his conception of communism, is the "[f]reedom [in which] ... the associated producers[] govern the human metabolism with nature in a rational way, bringing it under their collective control instead of being dominated by it ... [under] conditions most worthy and appropriate for their human nature." 3 MARX, CAPITAL, supra note 18 , at 959 . Or so he surmised.

${ }^{26}$ MiLL, supra note 4 , at 789.

${ }^{27} \mathrm{Id}$. at $778-79$. "From the progressive advance of the co-operative movement, a great increase may be looked for even in the aggregate productiveness of industry." $I d$. at 789.

${ }^{28} I d$. at 763 .

${ }^{29} \mathrm{Id}$. at 758. "Democracy" was a pejorative term in the mid-nineteenth century, not least for Mill. His concerns about the "tyranny of the majority," JOHN STUART MILL, ON LIBERTY (1859), reprinted in UTILITARIANISM AND OTHER WRTINGS 126, 129-30 (Mary Warnock ed., 1962), a term derived from 1 ALEXIS DE TOCQUEVILLE, DEMOCRACY IN AMERICA 265 (Henry Reeve et al. trans., Knopf 1972) (1835), led him to view the term democracy, with his contemporaries, in a doubtful light even when he supported aspects of what we mean by it, including self-governance.

${ }^{30}$ MILL, supra note 4, at 792 . "[W]ith the exception of competition among labourers, all other competition is for [their] benefit . . . by cheapening the articles they consume ...." Id. "To be protected against competition is to be protected in idleness, in mental dulness; to be saved the necessity of being as active and as intelligent as other people ..." Id. at 79394. 
any sudden disturbance of existing habits and expectations." 31 Associations would multiply and tend to "absorb all work-people." ${ }^{2}$ Capitalists would "find it to their advantage" to give up class conflict and "lend their capital to the associations... and at last... to exchange [it] for terminable annuities. In ... some such mode, the existing accumulations of capital might honestly, and by a kind of spontaneous process, become ... the joint property of all who participate in their productive employment." 33 For Mill, the market itself would quietly and gradually abolish capital management in favor of labor management, an idea that Marx would scorn with all his rhetorical power. ${ }^{34}$

\section{B. The Rarity of Labor Management}

\section{Where Mill Was Right}

Mill was broadly correct about the advantages of cooperatives. Richard Freeman and Joel Rogers ${ }^{35}$ summarize the results of their study of Employee Involvement (EI) plans in capitalist firms, ${ }^{36}$ by saying that EI "programs make

${ }^{31}$ Id. at 791. As is well known, Marx believed that the "ends [of the Communists] can be attained [in general] only by the forcible overthrow of all existing social conditions." MARX, MANIFESTO, reprinted in MARX-ENGELS READER, supra note 18, at 500.

${ }^{32}$ MiLL, supra note 4, at 791 .

${ }^{33} \mathrm{Id}$.

${ }^{34}$ Marx thought that cooperative labor-managed production showed that capitalists are "superfluous," 3 MARX, CAPITAL, supra note 18, at 511 , but under capitalism it necessarily reproduced "all the defects of the existing system," abolishing the opposition between capital and labor "at first only in the form that the workers in association become their own capitalist." Id. at 571 . He did briefly suggest that cooperative credit arrangements owned by workers "present[] . . the means for the gradual extension of cooperative enterprises on a more or less national scale," $i d$. at 571-72, but he treated cooperatives on par with "[c]apitalist joint-stock companies," $i d$. at 572, a penetrating comparison that I use for my own purposes below, see infra notes 126-133 and accompanying text, as "transition forms from the capitalist mode of production to the associated one," 3 MARX, CAPITAL, supra note 18 , at 572.

${ }^{35}$ See generally RICHARD B. FREEMAN \& JOEL ROgERS, WHAT WORKERS WANT (1999).

${ }^{36}$ Freeman and Rogers examined capitalist firms with and without EI programs, including "quality circles and discussion groups, total quality management, self-directed work teams, safety committees, [and other structures]," which do not give the workers much real say in firm operation and policy. See id. at 101; see also Stephen M. Bainbridge, Participatory Management Within a Theory of the Firm, 21 J. CoRP. L. 657, 688 (1996) ("[O]ne nearly universal characteristic of operational participation is a lack of meaningful employee control over the outcome of the decisionmaking process."). Most such programs "focus on issues relating to production." FREEMAN \& ROGERS, supra note 35, at 102. U.S. labor law prohibits capitalist firms from establishing employee groups to assist in determining wages, benefits, or working conditions. See National Labor Relations Act $\S 8(\mathrm{a})(2), 29$ U.S.C. $\S 158(\mathrm{a})(2)$ (2006). Legal barriers, however, cannot be the main explanation for the emptiness of existing employee participation programs, given the infrequency of enforcement and the willingness of firms and employees to disregard the law. 
workers' lives better.... [S]tudies... suggest that, at a minimum, such programs do not harm productivity on average and, more likely than not, raise it. Most workers want these programs and want them to become more extensive, giving workers greater say." 37 Participatory forms with employee ownership are more productive. ${ }^{38}$ Capitalists may have little interest in offering worker participatory options. ${ }^{39}$ In part because of the rarity of labor-managed firms, data are thinner but available results are similar. Although the results are highly sensitive to social context, workers in cooperatives also benefit from labor management in comparison with capital management. ${ }^{40}$ In the labor-

See Schwartz, supra note 2 (manuscript at 11-14 nn.71-85); see also FREEMAN \& ROGERS, supra note 35, at 102-03 (stating that much illegal discussion of this sort nonetheless occurs in EI programs). Capitalists nonetheless rarely consult workers on strategic questions of financing, investment, long-range plans, or marketing. Participation is largely limited to "operational" shop floor issues, and almost exclusively merely advisory in character. Employees strongly prefer more participation, even so limited. FREEMAN \& ROGERS, supra note 35 , at 138 .

${ }^{37}$ FREEMAN \& ROGERS, supra note 35, at 116 . Their research showed that EI programs give capitalist firms a $2 \%-5 \%$ productivity advantage over ones without. Id. at 105 . Other studies indicate more dramatic advantages. A Columbia Business School study of 495 firms found that production workers in those firms with the most employee participation and profit sharing were $19 \%$ more productive than those with the least. Daniel J.B. Mitchell et al., Alternative Pay Systems, Firm Performance and Productivity 49, 55a tbl.8 (Brookings Inst. Conference on Worker Comp. \& Productivity, Working Paper Series No. 165, Second Draft, 1989), available at http://cdn.calisphere.org/data/28722/4t/bk0003v174t/files/bk0003v174tFID1.pdf. For more data, see Schwartz, supra note 2 (manuscript at Part II.C). In that Article, I address the question, parallel to that raised here, "Why doesn't every firm do it?," that is, institute genuine employee participation that gives workers real say in enterprise management.

${ }^{38}$ Participation enhances productivity most when combined with profit sharing, job security, narrow wage differentials, enhanced worker rights, and job security. David $I$. Levine \& Laura D'Andrea Tyson, Participation, Productivity, and the Firm's Environment, in PAying For Productivity: A LOOK AT THE EVIDENCE 183, 203 (Alan S. Blinder ed., 1990) [hereinafter PAYING FOR PRODUCTIVITY], cited in SCHWEICKART, AGAINST, supra note 5, at 100 nn.51-52; see also Martin L. Weitzman \& Douglas L. Kruse, Profit Sharing and Productivity, in PAYING FOR PRODUCTIVITY, supra, at 95, cited in Bainbridge, supra note 36, at 703 n.280.

${ }^{39}$ Why capitalists do not rely more on worker participation, given its efficiency advantages, is a further puzzle, in many ways no less perplexing that the one I consider here. For my answer, see Schwartz, supra note 2 (manuscript at Part III)-essentially that it diminishes their own control over and potentially their share of firm profits.

40 Work satisfaction in the U.S. plywood cooperatives of the Pacific Northwest was higher than in capitalist plants, EDWARD S. GREENBERG, WORKPLACE DEMOCRACY: THE POLITICAL EFFECTS OF PARTICIPATION 92-93 (1986), although $60 \%-66 \%$ of the plywood cooperators said that if they were to leave, they either would not care whether they worked in a cooperative $(50.6 \%)$ or would prefer not to. Id. at $89-90$. Mondragón cooperators were far more positive, with $96 \%$ of a survey sample agreeing that they made the correct decision when they joined. THOMAS \& LOGAN, supra note 16, at 190-91. Reviewing international comparisons with the U.S. plywood cooperatives, Mondragón, the former Yugoslavia, and the kibbutzim, Greenberg, writing in 1986, stated that "[w]ithout exception, each of [these 
owned cooperative, no group of owners or investors apart from the workers themselves ${ }^{41}$ need control production. Worker-owners who claimed the entire residual enterprise income as their own and also determined management practices would seem to have a strong incentive, other things being equal, to choose the most productive organizational forms. And with respect to productivity, cooperatives fare at least as well if not better than their capitalist competitors. U.S. producer cooperatives have higher labor productivity than capitalist firms in many cases. ${ }^{42} \mathrm{~A}$ review of eleven economic studies of the effect of worker decision making on productivity in labor-managed firms found that the "relationship was positive in seven cases, negative in two, and zero in two." 43 The plywood cooperatives of the Pacific Northwest showed a 6\%-15\% productivity advantage over conventional mills. ${ }^{44}$ The Mondragón cooperatives of Spain "are more efficient than many private enterprises" on several measures of productivity and "have been more profitable than capitalist enterprises." 45 In the mid-1970s, Seymour Melman found that the highly democratic Israeli kibbutzim "showed higher productivity of labor $(26 \%)$, higher productivity of capital $(67 \%$ and $33 \%)$, larger net profit per production worker $(115 \%)$ and lower administrative cost (13\%)."46 In the mid-1980s, most kibbutzim experienced serious economic problems, ${ }^{47}$ apparently due to soaring debt at a time of severe inflation, together with unwise stock market speculation. ${ }^{48}$

sorts of] self-managed enterprises ... has made solid advances" in areas "having to do with control over the product and the [profits] realized after its sale, formal decision-making processes concerning the enterprise, and work satisfaction." GREENBERG, supra, at 113-14.

${ }^{41}$ Cooperatives require capital, and perhaps may need more than workers can generate from their own resources or even from the income stream of an established enterprise. Dow and others argue that it is the lack of investor confidence in repayment by cooperatives that largely explains why this organizational form is rare. See Dow, supra note 7, at 188-89, 236-38. I address this explanation in Part III.C.

42 Derek Jones, U.S. Producer Cooperatives: The Record to Date, 18 INDUS. REL. 342, 348-49 (1979).

${ }^{43}$ Dow, supra note 7, at 183 (citing Chris Doucouliagos, Worker Participation and Productivity in Labor-Managed Firms and Participatory Capitalist Firms: A Meta-Analysis, 49 INDUS. \& LAB. REL. REV. 58, 58-77 (1995)).

${ }^{44}$ Id. at 183 (citing Ben Craig \& John Pencavel, The Behavior of Worker Cooperatives: The Plywood Companies of the Pacific Northwest, 82 AM. ECON. REV. 1083, 1083-105 (1992)).

45 THOMAS \& LOGAN, supra note 16 , at 109 . It is telling that cooperative employment in manufacturing made up only about $3 \%$ of the Basque population so employed, but cooperative investment was about $77 \%$ of all Basque industrial investment. See WHYTE \& WHYTE, supra note 16 , at 219 (1981 figures).

${ }^{46}$ Seymour Melman, Industrial Efficiency Under Managerial Versus Cooperative Decision-Making: A Comparative Study of Manufacturing Enterprises in Israel, in 2 SELFGOVERNING SOCIALISM SOCIOLOGY AND POLITICS / ECONOMICS 203, 210 (Branko Horvat et al. eds., 1975).

${ }^{47}$ See GAVRON, supra note 16 , at 139 (noting that only 45 or so of the 270 kibbutzim remained in a prosperous or reasonably good financial situation). Gavron's conclusions are ambiguous if not actually inconsistent. He states that "some fifty relatively successful 
Another comparative dimension is the "death" rates of labor-managed firms versus capital-managed firms. A 1988 study of the "death" rates from all sources, including dissolution and conversion to capitalist firms, showed that the relative rates in France were $6.9 \%$ for labor-managed firms and $10 \%$ for capital-managed manufacturing firms; in the U.K., $6.3 \%$ for labor-managed firms to $10.5 \%$ for all industries, and $9.3 \%$ in Italy, where the cooperative sector is among the strongest in the world. ${ }^{49}$ Dow concludes that labor-managed firms are "not rare because they fail disproportionately often. Once created, they appear robust. Rather, they are rare because in absolute numbers they are created much less often than [capital-managed firms]." 50

Furthermore, labor-managed firms do actually tend to embody many of the democratic and labor-friendly features that Mill and other advocates of this form of organization hoped for: employment security, egalitarian pay scales,

kibbutzim prove than the system can work," id. at 152 , but also that the seven-decade survival of the kibbutz was "in some ways an optical illusion," id. at 157. "[T] he economic failure of many kibbutzim was hidden from view," $i d$., because "in previous economic crises somebody was always available to pick up the tab," $i d$. at 154, including the other kibbutzim and the Israeli government. Economists call this "moral hazard," that is, "the greater tendency of people who are protected from the consequences of risky behavior to engage in such behavior." Steven L. Schwarcz, Systemic Risk, 97 GEO. L.J. 193, 209 (2008).

After the near collapse of the capitalist financial system in 2008 , the difference with respect to efficiency between the need for a guarantor of last resort for the kibbutzim and many of the largest U.S. corporations is far from evident. See generally RICHARD A. POSNER, A FAILURE OF CAPITALISM: THE CRISIS OF '08 AND THE DESCENT INTO DEPRESSION (2009) (analyzing the causes of current crisis and considering the government's response and possible alternatives); ANDREW ROSS SORKIN, TOO BIG TO FAIL: THE INSIDE STORY OF HOW Wall StreEt and Washington Fought to SAVE THE FINANCIAL SYSTEM FROM CRISISAND THEMSELVES (2009) (discussing, inter alia, the Troubled Asset Relief Program (TARP) and its enabling legislation, the Emergency Economic Stabilization Act of 2008, Pub. L. No. $110-343, \S 101,122$ Stat. 3765,3767 (to be codified at 12 U.S.C. $\S 5211$ ), which pumped over $\$ 1$ trillion into the coffers of America's largest corporations).

${ }^{48}$ See GAVRON, supra note 16 , at 144-45 (discussing inflation, debt, and stock speculation). Gavron attributes the crisis, ultimately, to a decay in the kibbutzim's original utopian motivations as market pressures and consumerism triumphed over the egalitarian values that had sustained the kibbutzim for most of the twentieth century. Id. at 283. Degeneration for various reasons is a problem for labor-managed firms. See Dow, supra note 7, at 234-36; discussion infra note 191. But this is not the issue that occupies us here.

${ }^{49}$ See Dow, supra note 7, at 226 (citing Avner Ben-Ner, Comparative Empirical Observations on Worker-Owned and Capitalist Firms, 6 INT'L J. INDUS. ORG. 7, 14-15 (1988)). Dow remarks that the death rate for labor-managed firms in the Netherlands and Sweden is over four times that in France or the United Kingdom but attributes this to the cooperative sector in those countries being smaller and newer. Id. With regard to Italy, the firm survival rate over time (the obverse of the firm death date) for manufacturing firms in the entire economy, including both capital-managed firms and labor-managed firms, is comparable to that in France and the United States and higher than in the United Kingdom or Canada. See Eric Bartelsman et al., Comparative Analysis of Firm Demographics and Survival: Evidence from Micro-Level Sources in OECD Countries, 14 INDUS. \& CORP. CHANGE 365, 382-87 (2005).

${ }^{50}$ Dow, supra note 7 , at 227. 
genuine participation with managerial authority in all aspects of firm policy, transparency as to finances, and democratic control of the enterprise, among other attractions. ${ }^{51}$ In sum, Mill was right about the efficiency advantages and other appeals of labor management. But this only heightens the puzzle.

\section{Where Mill Was Mistaken}

Mill was mistaken, and Marx correct, at least about the tendency for labormanaged firms to displace capital-managed firms in the ordinary operation of the market. Producer cooperatives remain a decidedly minor form of productive organization. Part of the issue is definitional: what is a labor-managed firm and is it the same thing as a cooperative? We may understand labor (self) management ${ }^{52}$ for our purposes to be analogous to capital management: in the

${ }^{51}$ Members of the plywood cooperatives, apart from the higher-paid general managers, "normally receive[d] equal pay." Id. at 53 (citing Craig \& Pencavel, supra note 44). Members were guaranteed a job at the prevailing wage, and virtually no members were ever fired. $I d$. at 54 . "[T] he ability of the organization to discharge an owner is severely restricted." Id. at 55 (quoting CARL J. BELLAS, INDUSTRIAL DEMOCRACY AND THE WORKEROWNED FIRM: A STUdY OF TWENTY-ONE PlyWOOd COMPANIES IN THE PACIFIC NORTHWEST 25 (1972)). The directors were currently employed owner-workers, and members had access to and used firm data and documents. Id. at 54. "In general, the co[-]ops exhibit[ed] a robust form of organizational democracy, where representative institutions are reinforced by rather widespread participation on the part of individual workers." Id. (citing Edward S. Greenberg, The Plywood Cooperatives and Democratic Theory: The Case of the Plywood Firms, in WORKER COOPERATIVES IN AMERICA 171-214 (Robert Jackall \& Henry M. Levin eds., 1984)). In Mondragón, workers elect a Governing Council annually, which appoints managers. Id. at 59. Before 1987, the ratio between the lowest and highest wages was $1: 3, i d$. at 60 ; after 1987, it widened to $1: 6, i d$. at 63 . Mondragón cooperatives laid off no members prior to 1983 , and, after that, only 30 of the (then) 18,000 members had to use Mondragón's internal unemployment insurance. $I d$. at 62 . Increased managerial authority and use of hired labor have raised questions about how democratic Mondragón has remained. Id. See generally GEORGE CHENEY, VALUES AT WORK: EMPLOYEE PARTICIPATION MEETS MARKET Pressure at MONDRAgÓN (1999); SHARRYN KaSMIR, THE MYTH OF MONDRAGÓN: CoOPeratives, Politics, AND Working-Class LifE IN A BASQUE TOWn (1996). But Dow states that Mondragón has "retained democratic internal structures at the level of the individual coops." Dow, supra note 7, at 64 ; see also infra notes $135,137$.

52 It is common in the literature to refer to an enterprise in which management decisions are made by workers themselves, their elected representatives, or hired managerial employees as a worker self-managed firm, perhaps for emphasis and perhaps because "labor management" could be ambiguous between the management of labor by capital, or in any event not by workers, and management of labor by employees themselves. For the sake of greater brevity and parallelism with "capital management" (itself, incidentally, potentially similar in its ambiguity), I mean by labor management throughout the management of the enterprise primarily by, or under the control of, the workers who work there. Moreover the characterization of traditional capitalist firms as capital-managed firms (KMFs) and worker cooperatives as labor-managed firms (LMFs) is now standard in the literature. See, e.g., infra note 53. I refrain from the acronyms because they are less familiar to the wider audience of legal economists, corporate and employment and labor law scholars, and interested general readers I hope to reach. 
capital-managed firm, ultimate control rests with the investors or their representatives, while in the labor-managed firm, ultimate control rests with the workers or their representatives. ${ }^{53}$ For reasons I discuss elsewhere, ${ }^{54}$ all or virtually all existing labor-managed firms in capitalist societies are worker cooperatives, that is, worker-owned enterprises, ${ }^{55}$ but not vice versa. ${ }^{56}$ Terms like "labor-owned" and "labor-managed" are often used interchangeably in the literature-which, like Hansmann, often focuses at least formally more on ownership than control ${ }^{57}$-leading to some confusion about the topic of

${ }^{53}$ See Dow, supra note 7, at 5 . Dow refines this rough distinction by saying that "[a] capital-managed firm (KMF) is defined as an enterprise in which ultimate control is allocated by virtue of, and in proportion to, capital supply, while a labor-managed firm (LMF) assigns control by virtue of, and in proportion to, labor supply." Id. Schweickart defines worker self-management by saying: "Each productive enterprise is managed democratically by its workers." SCHWEICKART, AGAINST, supra note 5 , at 68 . He continues:

Each productive enterprise [a term he does not define] is managed by those who work there. Workers are responsible for the operation of the facility: organization of the workplace, factory discipline, techniques of production, what and how much to produce, how the net proceeds are to be distributed. Decisions concerning these matters are made democratically: one person, one vote. Of course, in a firm of significant size, some delegation of authority will doubtless be necessary.

Id. (footnote omitted). Christopher Gunn offers a three-part definition of what he calls "worker's self-management": (1) shared goals, including but not exhausted by "maximizing income per worker"; (2) "absence of direct external control, either by capital owners or by an autocratic governmental hierarchy"; and (3) "process based on democratic principlesrules and procedures that allow all participants an equal voice in the management of the organization." CHRISTOPHER EATON GUNN, WORKERS' SELF-MANAGEMENT IN THE UNITED STATES 17-18 (1984). Hansmann, whose official main focus is on comparing ownership rather than management structures, does not attempt to define any practice of labor management. See generally HANSMANN, ENTERPRISE, supra note 2. For reasons of simplicity, and because I do not wish to build in as a matter of definition, any particular form of control such as one-worker/one-vote, I adopt Dow's more austere conception.

${ }^{54}$ See generally Schwartz, supra note 2 (offering an explanation of why genuine participation and more or less full labor ownership are causally linked).

${ }_{55}^{5}$ Schweickart's self-managed firms would not be cooperatives, so defined. "Although workers manage the workplace, they do not own the means of production. These are the collective property of the society." SCHWEICKART, AGAINST, supra note 5, at 69; accord MiCHAEl W. HowARD, SElF-MANAGEMENT AND THE CRISIS OF SOCIALISM: THE ROSE IN THE FIST OF THE PRESENT 14-15 (2000) (defending Schweickart's view).

56 In their American Bar Association study of the law of cooperatives, Charles Autry and Roland Hall fail to include labor management as a feature of the cooperative. They define a cooperative as one owned and democratically controlled by "the people who use its services or buy its products." CHARLES T. AUTRY \& ROLAND F. HALL, THE LAW OF COOPERATIVES 2 (2009). It is possible that "use of services" includes employment, but Autry and Hall do not elaborate.

${ }^{57}$ See HANSMANN, ENTERPRISE, supra note 2, at 11 (stating that "[a] firm's 'owners' ... are those persons who share two formal rights: the right to control the firm and the right to appropriate the firm's profits, or residual earnings" and noting that "[f]ormal control ... does not necessarily mean effective control"); see also id. at 13 (defining, in a 
discussion and the causal structure of the phenomenon to be explained. Labor ownership, to a greater or lesser degree, need not involve labor management. At least in the United States, where (more or less partial) labor ownership typically takes the form of the Employee Stock Ownership Plan (ESOP), ${ }^{58}$ it typically does not involve labor management, and may not even involve a significant degree of labor participation. Accordingly, I only devote attention to forms of labor ownership, such as ESOPs, where "control over the firm generally remains in other hands," 59 insofar as these provide evidence about labor management. I set aside the German policy of legally enforced "codetermination" (Mitbestimmung), which involves worker representation on the boards of large firms, ${ }^{60}$ but which seems to have little if any measurable effect on firm operation or performance. ${ }^{61}$ Although I have adopted the austere

hypothetical example of a milk co-op, "ownership rights [as being] held by virtue of, and proportional to, one's sale of milk to the firm" (emphasis added)). When Hansmann, among other writers, treats concrete examples, such as the U.S. plywood cooperatives or Mondragón in Spain, his focus tends to be more on control, specifically on the sort of managerial decisions that Schweickart mentions. See generally SCHWEICKART, AGAINST, supra note 5 . Those are typically included in the bundle of rights that comprise ownership, but Hansmann's right to appropriation of residual earnings need not include managerial rights. See also Dow, supra note 7, at 2-3, 113 (illustrating with useful tables how ownership and control are independent dimensions of firm organization).

${ }^{58}$ ESOPs, enabled by legislation introduced beginning in 1973 by Senator Russell Long, son of Huey Long ("the Kingfish," a former Louisiana governor and a populist U.S. senator), are deferred compensation or qualified retirement plan under ERISA and the tax code. Today there are roughly 11,000 such plans covering roughly ten million employees. See Andrew W. Stumpff, Fifty Years of Utopia: A Half-Century After Louis Kelso's The Capitalist Manifesto, A Look Back at the Weird History of the ESOP, 62 TAX LAW. 419, 431 $\&$ n.75 (2008). Kelso, an economist turned banker, was the intellectual entrepreneur who sold Senator Long, Chairman of the Senate Finance Committee and a populist himself, on the idea. Id. at 420-21. See generally JOSEPH RAPHAEL BlaSI \& DOUGLAS LYNN KRUSE, THE NEW OWNERS: THE MASS EMERGENCE OF EMPLOYEE OWNERSHIP IN PUBLIC COMPANIES AND WHat IT MEANS to AMERICAN Business (1991); Louis O. Kelso \& MORTIMER J. ADLER, THE CAPITALIST MANIFESTO (1958).

${ }^{59}$ HANSMANN, ENTERPRISE, supra note 2, at 69. In 1986, a federal government survey of 3000 ESOPs found formal employee involvement in decision making in no more than $15 \%$, "informal" participation in $76 \%$, but largely restricted to safety, working conditions, and other immediate worker concerns (overall $42 \%-30 \%$ ) rather than organizational goals or means to meet them (overall 13\%-11\%); moreover, while overall $95 \%$ of the surveyed firms allowed workers to make suggestions and $33 \%$ allowed some degree of shared decision making with management, only in $10 \%$ of the surveyed ESOPs did employees make decisions on their Own. JOSEPH RAPHAEL BLASI, EMPLOYEE OWNERSHIP: REVOLUTION OR RIPOFF? 202-04 (1988) (citing U.S. GoV'T ACCOUNTABILITY OFFICE, GAO/PEMD-87-8, EMPLOYEE STOCK OWNERSHIP PLANS: BENEFITS AND COSTS OF ESOP TAX INCENTIVES FOR BROADENING STOCK OWNERSHIP 41-43 (1986)).

60 See, e.g., Dow supra note 7, at 83-91.

${ }^{61}$ See HANSMANN, ENTERPRISE, supra note 2, at 111-12 ("[C]odetermination has not had a substantial impact on firm decision making at the board level, which continues to be dominated by shareholder interests .... [W] [ ] rker representatives ... arguably play a largely informational role ... [and do not appear to] exercise meaningful control."). 
definition of a producer cooperative for analytical purposes, labor management and ownership in producer cooperatives are generally associated with egalitarian and democratic organizational features that distinguish them from capitalist enterprises and which constitute their main interest to Mill and most modern students. ${ }^{62}$

The terminological imprecision also creates difficulty in arriving at even rough measures of the rarity of the labor-owned or labor-managed firm in modern market economies. The broad outlines, however, are clear even if numbers vary: essentially, labor management is a "peripheral form of organization that prospers only in narrow niches." 63 According to the Census Bureau, in 2002 there were 5,697,759 firms in the United States, of which 4,927,718 hired employees. ${ }^{64}$ A 2005 survey by the University of Wisconsin Center for Cooperatives (UWCC) found 21,367 cooperatives in six sectors, none industrial or manufacturing; and a 2004 UWCC study counted 400 worker cooperatives, excluding ESOPs. ${ }^{65}$ Hansmann's 1991 figures for farm marketing and producing cooperatives are broadly consistent with these results. ${ }^{66}$ Based on

62 See supra note 51 and accompanying text; see also infra note 135.

${ }^{63}$ Dow, supra note 7 , at 47 . Speaking merely of employee ownership, such "firms are rare in the industrial sector of the American economy." HANSMANN, ENTERPRISE, supra note 2 , at 66.

${ }^{64}$ Statistics of U.S. Businesses: 2002, U.S. CENSUS BUREAU, http://www.census.gov/epcd/susb/2002/us/US--.HTM (last modified July 13, 2011).

${ }^{65}$ The University of Wisconsin's Center for Cooperatives (UWCC) counted 21,367 cooperatives. Nat'l Coop. Month Planning Comm., Cooperative Business in the United States ...: A 2005 Snapshot, U. OF WIS. CENTER FOR COOPERATIVES, 4 (Oct. 2005), http://www.uwcc.wisc.edu/info/stats/uscoopbus05.pdf. The sectors were agricultural, financial (credit union and farm credit), electric utilities, grocery, and housing. Id. at 1 . The Committee noted that other sectors including "worker co-ops ... were not easily covered in the survey." Id. at 3 . The agricultural and electrical power co-ops surveyed were the closest things to productive firms, and involved revenues and assets in the billions. Id. at 4 . Autry and Hall gleaned from U.S. government sources a figure of 47,000 cooperatives. See AUTRY \& HALL, supra note 56, at 4 . Their definition of cooperatives, which excludes labormanaged firms, must be taken into account in assessing the usefulness of this figure for our purposes. According to a 2004 study by the UWCC,

There are approximately 400 worker co-ops [distinguished from ESOPs] in the U.S. In general, they are $100 \%$ worker-owned and ascribe to the cooperative principle of 'one member, one vote'. They vary widely in their management and pay structures, from remarkably 'flat' to more conventionally hierarchical. The country's largest worker owned co-op is Cooperative Home Care, a home health care agency in the Bronx ... With 780 employees .... Most worker co-ops are much smaller, ranging from 20-200 employee-owners.

Greg Lawless \& Anne Reynolds, Worker Cooperatives: Case Studies, Key Criteria, and Best Practices 3 (Univ. of Wis. Ctr. for Coops. Staff Paper No. 3, 2004) (emphasis added), available at $\mathrm{http}: / / \mathrm{www} . u w c c . w i s c . e d u / p d f / S t a f f \% 20 \mathrm{Papers} / \mathrm{staff03}$.pdf.

${ }^{66}$ See HANSMANN, ENTERPRISE, supra note 2, at 120 . He also discusses retail, wholesale and supply firms, utilities, clubs, housing, nonprofits, banks, and insurance. Id. at 67. In addition, more questionably, Hansmann treats law firms and other sorts of 
these figures, worker cooperatives, that is, worker-owned and -managed firms, excluding ESOPs and professional service partnerships, constituted $0.007 \%$ of U.S. producer firms with employees. "Peripheral" is, if anything, a gross overstatement. Such firms can have more economic weight than their size and rarity would indicate. The plywood cooperatives were the most successful labor-owned and -managed industrial enterprises in the United States in the twentieth century. ${ }^{67}$ At their height in the early 1960 s, roughly twenty-seven plywood manufacturers, each employing several hundred workers, were cooperatives. They accounted for $25 \%$ of the industry's output during World

professional partnerships as labor-owned and labor-managed enterprises. Id. (" $[\mathrm{P}]$ artnerships and professional corporations common in the service professions ... [as] among the world's purest examples of employee ownership.... [These professions] are virtually the only industries that are dominated by employee-owned firms."). Dow states without discussion that professional partnerships are "arguably the largest category of worker-controlled enterprise in modern economies." Dow, supra note 7, at 49-50. He does not give this form of cooperative management and ownership significant discussion in his account, concentrating instead on classically understood producer cooperatives.

While smaller law and other professional service firms organized as partnerships may approximate producer labor management and ownership, there is significant variation. The larger firms are, unlike standard labor-managed enterprises, extremely "hierarchical." Marc Galanter \& Thomas M. Palay, Why the Big Get Bigger: The Promotion-to-Partner Tournament and the Growth of Large Law Firms, 76 VA. L. REV. 747 (1990), reprinted in LAWYERS: A CRITICAL READER 57 (Richard L. Abel ed., 1997). The average ratio of associate employees and nonequity partners to equity partners among the AmLaw 200 highest grossing law firms is 2.40:1. See Benjamin L. Landis, Financial Health Indicators Diverge Wildly Among AMLAW 200 Firms, Of CouNS., June 2004, at 10, 11. Even an overall average counting smaller law firms indicates that hired employees are common in smaller firms. "The average ratio of associates to partners in law firms nationwide was .67 in 2005 (i.e., 67 associates for every 100 partners)." Firm Finances, PARTNER's REP.-A MONTHLY BRIEF FOR L. FIRM OWNERS, Oct. 2006, at 4, 5 . Accounting firms were far more skewed. "The Big Six are generally characterized by taller hierarchies and considerably higher associate-to-partner ratios. . . . For example, in 1989, Arthur Andersen \& Co., one of the [then-]Big Six, had 40,136 professional personnel, of whom 2,405 (6.0\%) were partners." Marc Galanter \& Thomas Palay, The Many Futures of the Big Law Firm, 45 S.C. L. REV. 905, 913 (1994).

Moreover, larger professional partnerships rarely embody the democratic structures characteristic of producer cooperatives. "[U]ndemocratic corporate law firms," Laura Nader, Controlling Processes in the Practice of Law: Hierarchy and Pacification in the Movement to Re-Form Dispute Ideology, 19 OHIO ST. J. ON DISP. RESOL. 1, 23 (1993), is virtually a redundant expression. Some courts are coming to recognize that under an economic reality test, a mere ownership share does not make even some equity law firm partners anything more than de facto employees in the traditional sense. See, e.g., EEOC v. Sidley Austin Brown \& Wood, 315 F.3d 696, 706 (7th Cir. 2002); see also David B. Wilkins, Partner, Shmartner! EEOC v. Sidley Austin Brown \& Wood, 120 HARV. L. REV. 1264 passim (2007). For these reasons, among others, I set aside data regarding professional partnerships as not pertinent to the issue of genuine labor management and ownership.

${ }^{67}$ See GREENBERG, supra note 40, at 28; see also Dow, supra note 7, at 50-57; GuNN, supra note 53, at 99-131 (citing studies). 
War II, diminishing to about $10 \%$ by the 1960 s and 1970 s. ${ }^{68}$ However, just three remained labor-managed cooperatives at the turn of the twenty-first century. ${ }^{69}$

The situation is notably less dismal for the labor-managed firm elsewhere. ${ }^{70}$ Italy had around 11,000 labor-managed firms employing 428,000 workers in 1981. France had 1300 labor-managed firms with roughly 34,000 workers in $1986 .{ }^{71}$ Since the beginning of the last century Israel has had the kibbutz, which

${ }^{68}$ See GuNN, supra note 53, at 100-02. "'The plywood cooperatives are not a movement but a phenomenon. Excluding the four earliest mills, this phenomenon took place between 1949 and 1955." Dow, supra note 7, at 53 (quoting BELLAS, supra note 51, at 31).

${ }^{69}$ Dow, supra note 7, at 50 (citing JOHN PENCAVEL, WORKER PARTICIPATION: LessONS FROM THE WORKERS CO-OPS OF THE PACIFIC NORTHWEST (2001)).

${ }^{70}$ Outside the industrialized West, the labor-managed (but not labor-owned) firm became the predominant organizational form in the former Yugoslavia for roughly forty years, between 1950 and the self-destruction of Yugoslavia in 1989. See generally JOEL DiRlam \& James Plummer, AN INTROdUCtion to THE YugoslaV ECONOMY (1973); MILOVAN DJILAS, THE UNPERFECT SOCIETY: BEYOND THE NEW ClASS (Dorian Cooke trans., 1969); BRANKo HoRVAT, THE Yugoslav ECONOMIC SYSTEM: THE FIRST LABOR-MANAGED ECONOMY IN THE MAKING (1976); HAROLD LYDALL, YUGOSLAV SOCIALISM: THEORY AND PRACTICE 191 (1984) ("Yugoslavia did remarkably well for thirty years [until the mid1980s.]"). Lydall is a harsh critic of the Yugoslav model.

The causes of the Yugoslav economic crisis and its relation to the bloody collapse of the Yugoslav state will be debated for a long time to come. See generally, e.g., LENARD J. COHEN, BROKEN BONDS: THE DisinTEGRATION OF YUGOSLAVIA (1993) (explaining the collapse as a matter of political failure to accommodate competing regional needs); CATHERINE SAMARY, YUGOSLAVIA DISMEMBERED (Peter Drucker trans., 1995) (contending that the catastrophe was caused by regional resentment along nationalist lines due to neoliberalism and foreign intervention that encouraged ethnic cleansing); LOUIS SELL, SlOBODAN Milosovic AND THE DeSTRUCTION OF YUgOSLAVIA (2002) (attributing the collapse of Yugoslavia to nationalism and partisan politics); SUSAN L. WOODWARD, SOCIALIST UNEMPloymENT: The POLITICAL ECONOMY OF YUGOSLAVIA, 1945-1990 (1995) (arguing that international debt and failures of self-management created an intolerable level of unemployment that had centrifugal effects when it fell unequally on different republics within the Yugoslav federal system).

The Yugoslav experience is rich in lessons for the labor-managed firm and economy. However, Yugoslav labor management was imposed top down by the ukase of the Yugoslav Communist Party, see DJILAS, supra, at 220-23; SCHWEICKART, AGAINST, supra note 5, at 61 , and so its genesis is not pertinent to the question I address here, which is rather why labor-managed firms do not spontaneously flourish and marginalize capital-managed ones by the operation of market forces, as Mill predicted, rather than vice versa. For this, and for reasons of manageability, I here largely set aside the Yugoslav evidence.

${ }^{71}$ Dow, supra note 7, at 47. Earle gives a higher figure for Italy in 1986. See JOHN Earle, The Italian Cooperative Movement: A Portrait of the Lega Nazionale DELlE COOPERATIVE E MUTUE 203 (1986). Hansmann cites 1983 figures for France of "several hundred firms organized as worker cooperatives employing a total of roughly 40,000 persons, of whom 61 percent were members." HANSMANN, ENTERPRISE, supra note 2, at 67 (citing ROBERT OAKESHOTT, THE CASE FOR WORKERS' CO-OPS $145-46$ (1978)). For Italy, he cites 1980 figures showing "several thousand worker cooperatives employing a total of roughly 215,000 persons." Id. (citing MARK HOLMSTROM, INDUSTRIAL DEMOCRACY 
comprises of a combination of cooperative housing arrangements and productive enterprises. There were 267 kibbutzim in 2000 , ranging in size from 100 to 1000 members. ${ }^{72}$ A recent study describes the kibbutz movement, itself a rather special product of unique circumstances, as being "in a state of turmoil." "73

Hands down, the most successful, long-lasting experience with this form of organization is the Mondragón group in Basque country in northern Spain. ${ }^{74}$ Starting as a trade school in the early 1940s, Mondragón opened its first producer co-op with five workers in the mid-1950s. ${ }^{75}$ At the turn of the twentyfirst century, Mondragón had about 150 member cooperatives, ${ }^{76}$ including dozens of manufacturing firms, among them Spain's leading tool and die maker, its leading refrigerator manufacturer, ${ }^{77}$ as well as enterprises producing electronics, and some involved in education, research and development, and retail sales. ${ }^{78}$ It had about 42,000 employees, ${ }^{79}$ up from 15,000 in 1979,80 organized in cooperatives averaging about 225 workers each, ${ }^{81}$ and capped at 350-500 workers. ${ }^{82}$ Mondragón had $\$ 7$ billion in annual sales and was the tenth largest private firm in Spain. ${ }^{83}$ The failure rate of Mondragón member co-ops is less than 3\%. ${ }^{84}$ Mondragón has acquired or has representation in firms in about twenty other countries, including China, India, and several North African and Latin American countries, ${ }^{85}$ in part by converting capital-managed firms to

IN ITALY: Workers CO-OPS AND tHe SElf-Management Debate 6, 21 (1989); OAKESHOTTE, supra, at 123).

${ }^{72}$ GaVRON, supra note 16 , at 1 . The number has remained stable since 1954 . See SPIRO, supra note 16 , at 5.

${ }^{73}$ GAVRON, supra note 16 , at 1 . His conclusion is that with the decay of the idealistic and collectivist values that imbued the early kibbutzniks, id. at $158,187,282$, "[t] $]$ he kibbutzim will continue to exist as settlements[,] . . [but] they will not be kibbutzim," $i d$. at 283.

${ }^{74}$ Mondragón is the subject of a vast literature. Central studies include CHENEY, supra note 51, KASMIR, supra note 51; ROY MORRISON, WE BUILD THE ROAD AS WE TRAVEL: Mondragón, A COOPERATIVe Social SySTEM (1991); ThOMAS \& LOGAN, supra note 16; and WHYTE \& WHYTE, supra note 16.

75 See WHYTE \& WHYTE, supra note 16, at 33-35. The first cooperative, Ulgor, which made domestic appliances, was established in 1956 by five graduates of the school and the entrepreneurial founder, a priest named Don José María Arizmendiarrieta. See infra notes 277-89 and accompanying text.

${ }^{76}$ Dow, supra note 7 , at 64 .

77 ld.

${ }^{78}$ Id. at 61.

${ }^{79} \mathrm{Id}$. at 64 .

$80 \mathrm{Id}$. at 61 .

${ }^{81} \mathrm{Id}$.

82 Dow, supra note 7 , at 62 . This followed the cooperatives' only strike, at Ulgor, which had grown past 3000 workers. Id. at $61-62$.

${ }^{83}$ Id. at 64.

${ }^{84} \mathrm{Id}$. at 61 .

${ }^{85} \mathrm{Id}$. at 64 . 
cooperatives, ${ }^{86}$ but this highly successful organizational model has not been imitated much elsewhere. It shows no signs of either attracting large numbers of workers away from wage labor in capital-managed firms, contrary to Mill's prediction, ${ }^{87}$ or forcing capitalists to "plac[e] the operations of industry on such a footing." 88

Given that cooperatives are legal ${ }^{89}$ and workers, or indeed capitalists, might do as Mill suggested, why have they not done so? Thus, Jon Elster's pointed question: "If cooperative ownership is so desirable, why are there so few cooperatives?"90 More crisply, where did Mill go wrong?

\section{THREE TRANSACTIONS COST EXPLANATIONS}

\section{A. The Evolutionary Hypothesis, the Coasean Background, and Transactions Cost Analysis}

In a fundamental article in 1950, the economist Armen Alchian argued, on the model of natural selection in biological evolution, that markets select firms that embody features, such as organizational forms, which, for whatever reason they are adopted, are in some sense more efficient than the competition. ${ }^{91}$ "[T] he realization of profits is the criterion according to which successful and surviving firms are selected,"92 so that "if all firms are slightly different...those who have their fixed internal conditions closer to the ... optimum position [in a given set of conditions] [will] have a greater probability of survival ... . They will grow relative to other firms and become the prevailing type ...."93 In general, in a competitive environment " $[t]$ he force

${ }^{86} \mathrm{Id}$.

${ }^{87}$ See MiLL, supra note 4, at 760-61.

${ }^{88}$ Id. at $761-62$. Mill gives two grounds for this prediction: social and moral pressure in the face of class conflict, id., and economic advantage, as labor-managed firms would, Mill supposed, "tend more and more to absorb all work-people," id. at 791, leaving capitalists at a disadvantage in competition for labor.

${ }^{89}$ See HANSMANN, ENTERPRISE, supra note 2, at 85-87.

90 Jon Elster, From Here to There; or, if Cooperative Ownership Is So Desirable, Why Are There So Few Cooperatives?, in SocIALISM 93, 93 (Ellen Frankel Paul et al. eds., 1989). Unfortunately, Elster offers no answer. "The main argument of this paper is apparently inconclusive: we just don't know whether the observed lack of cooperatives is due to their inherent inferiority or to interactions with the non-cooperative environment." Id. at 110 .

91 Alchian, supra note 9, at 213. The appeal to the notion of "efficiency" raises questions about what is meant by that slippery term. See JULES L. COLEMAN, Efficiency, Utility, and Wealth Maximization, in MARKETS, MORALS, AND THE LAW 95, 97-98 (1988) (defining and explaining several common notions of efficiency). I discuss the meanings of "efficiency" further in Schwartz, supra note 2 (manuscript at Part II.A).

92 Alchian, supra note 9, at 213.

$93 \mathrm{Id}$. at 216 . It will be noticed that, like almost everyone else who writes on the subject, I use productivity-roughly, output per factor input-as a proxy for profitability. Direct profitability comparisons between capitalist firms and cooperatives are extremely scanty. David Schweickart suggested to me that one reason for this is that profit, thus profitability, 
of competitive survival ... [will] eliminat[e] higher-cost firms." 94 Applying this idea to the question at hand, as Alchian did only in passing, the philosopher $\mathrm{N}$. Scott Arnold stated that " $[\mathrm{t}]$ he organizational forms of business firms can be given an evolutionary explanation by reference to the market test of relative efficiency. If an organizational form ... is common and ... persist[s], then there is probably some efficiency advantage." 95 Alchian also emphasized that convergence due to competitive pressures is fueled by imitation, ${ }^{96}$ and that comparative efficiency of different "patterns of behavior and organization are predictable... if they are tried."97 I shall return to these important related qualifications. Granting Alchian's Darwinian hypothesis, if labor management offers efficiency advantages over traditional capitalist firms, should not cooperative forms of enterprise organization proliferate, ultimately marginalizing capital management in the way that, in fact, capitalist enterprise has marginalized cooperative organization? And if they have not, why is that?

The theory underlying the sort of objections considered here proceeds from the insight, assumed away in neoclassical economic models, ${ }^{98}$ is that economic interactions - transactions - are themselves costly. This is one of those points so obvious that it is in fact profound. It has had wide-ranging implications for economic analysis. In 1937, Ronald Coase argued famously that the economy is organized into firms instead of individuals contracting bilaterally with each other or all economic activity coming under the roof of a single firm, as in a planned economy, because the boundary between the firm and the market is drawn roughly at the point where it is more efficient for economic actors to organize their economic interactions "bureaucratically," in a firm-like manner,

means different things for these different forms of organization. Personal Communication with David Schweickart, Professor of Philosophy, Loyola Univ. Chi. (May 22, 2011). Profit is usually understood as net return on investment. Id. Net return is what is left after paying the cost of the factors of production, including, traditionally, labor, raw materials, machinery, rent or mortgage on real estate, interest on loans, taxes and the like. Id.

Schweickart's point was that for capitalist enterprises, labor is a cost: wages for workers mean less money for the investors and owners, but for cooperatives, labor is not a cost. The workers are the owners, so net return on their investment is their profit. This makes direct comparison difficult. It may be possible to construct metrics that control for the difference, but the informativeness of the results would be debatable. For this reason, productivity is probably a better measure when comparing capitalist firms to cooperatives. One uses the data one has, and, for the most part, the comparisons of all sorts of firms in the literature refer to productivity.

94 Alchian, supra note 9 , at 217.

95 ARNOLD, PhILOSOPHY AND ECONOMICS, supra note 11, at 102-05; Amold, Market Socialism, supra note 11, at 534 (citing Alchian, supra note 9). Amold, strictly speaking, addresses market socialism, not merely or only labor management, but his point applies to the more limited target as well.

96 Alchian, supra note 9 , at 218.

97 Id. at 220.

${ }^{98}$ See supra note 6. 
than contractually, by agreeing separately on each thing to be done. ${ }^{99}$ As Coase himself put it fifty years later:

Whether a transaction would be organized within the firm ... [or integrated] or whether it would be carried out on the market by independent contractors depended on a comparison of the costs of carrying out these market transactions with the costs of carrying out these transactions within an organization, the firm. ${ }^{100}$

Coase is generally regarded as offering an account of the existence and boundaries of traditional capitalist enterprises. However, nothing in Coase's insight requires traditional, hierarchical organization within the firm. The internal organization of the firms resulting from transactional efficiencies might be labor-managed and democratic ${ }^{101}$ even if a Coasean explanation of existence of the firms is correct.

Arnold and Hansmann offer arguments with very different, indeed, mutually inconsistent, transactions cost premises to explain the prevalence of traditional organizational forms. To some extent the explanations, particularly Hansmann's, are plausible and enlightening, and Arnold's, though defective, locate real issues that any enterprise, including a cooperative, must solve. However, they do not solve the problem addressed in this Article: why more cooperatives are not started. In addition to specific problems with each version, both suffer from three grave defects: (1) they are inconsistent with empirical evidence that supports the efficiency advantages of labor management, (2) they do not explain why the problems that supposedly beset cooperatives have not similarly inhibited the development and operation of corporations, and (3) their purported mechanisms kick in too late, explaining (if they do) why any cooperatives that have already been formed supposedly have certain features rather than why cooperatives are not formed to begin with.

\section{B. Transactions Costs Internal to the Enterprise}

\section{Arnold: The Fear of the Monitor Is the Beginning of Efficiency ${ }^{102}$}

Arnold begins with Alchain's "Darwinian" presumption of efficiency 103 that favors, he thinks, traditional organizational forms, or they would not

${ }^{99}$ R.H. Coase, The Nature of the Firm, 4 ECONOMICA 386 (1937), reprinted in R.H. COASE, THE FIRM, THE MARKET, AND THE LAW 33, 40 (1988).

${ }_{100}$ R.H. Coase, The Nature of the Firm: Origin, 4 J.L. ECON. \& ORG. 3, 17 (1988).

101 As noted, there is a rough correlation. See discussion supra note 51.

102 See Proverbs 9:10 (King James) ("The fear of the Lord is the beginning of wisdom.").

103 ARNOLD, PhILOSOPHY AND ECONOMICS, supra note 11, at 105; Amold, Market Socialism, supra note 11, at 533-34 (citing Alchian, supra note 9, at 218). 
flourish. ${ }^{104}$ For this to be more than handwaving, however, the explanation must identify specific comparative efficiencies on which traditional organization is superior. Arnold suggests, first, that the traditional capitalist firm is more efficient than the cooperative enterprise because it better solves a crucial public goods problem. 105 The problem concerns how to tie (monetary) reward to productivity where team production makes individual output hard to meter. ${ }^{106}$ Arnold claims that productive activity faces an $n$-person prisoner's dilemma: If shirkers-or as Arnold calls them, opportunists-get the same rewards as workers, it will be rational for all not to work (as hard), and productivity will suffer. ${ }^{107}$ To minimize this, recourse to a monitor with managerial powers is necessary. ${ }^{108}$ It is the monitor's job to "put the fear of God in the workers."109

Cooperatives use monitors as well. ${ }^{110}$ Arnold recognizes that as far as the Alchian-Demsetz account explains anything, it does not explain why the "bosses" (Arnold's term) 111 make crucial strategic investment decisions and supply the firm's capital.112 This, he says, is because production is most efficient if managers are capitalists or at least non-worker-investors, i.e., residual claimants and primary capital providers. ${ }^{113}$ The idea is that capitalists must bear the "total wealth consequences" of their decisions, which gives them an incentive to be smart and careful that they would not have if they were using

${ }^{104}$ ARNOLD, PhILOSOPHY AND ECONOMICS, supra note 11, at 106; Amold, Market Socialism, supra note 11 , at 535 . Amold cites Alchian \& Demsetz, supra note 2, which specifically defends the efficiency superiorities of the single-owner classic capitalist firm rather than the open corporation. See Alchian \& Demsetz, supra note 2, at 794-95. For a general comparison of the efficiency of various organizational forms, see Fama \& Jensen, Agency Problems, supra note 2, and Fama \& Jensen, Separation of Ownership, supra note 2. The distinction will be important shortly. See infra notes 127-56, 184-86, 221-28 and accompanying text.

105 Public goods are defined as goods that satisfy the common interests of members of a group and that members of the group share whether or not they contribute to the creation of those goods; that is, no group member can be excluded from a public good. See OLSON, supra note 14, at 14-15; see also infra Part IV.A (explaining the nature of a public goods problem).

106 ARNOLD, PhILOSOPHY AND ECONOMICS, supra note 11, at 106; Arnold, Market Socialism, supra note 11, at 535 (citing Alchian \& Demsetz, supra note 2, at 778-79).

${ }^{107}$ ARNOLD, PHILOSOPHY AND ECONOMICS, supra note 11 , at 106. Arnold defines opportunism as "self-interest seeking with guile," a broader notion than shirking. Arnold, Market Socialism, supra note 11, at 535 (quoting WILLIAMSON, INSTITUTIONS, supra note 10 , at 30 . For more on the prisoner's dilemma, see infra notes 253-58 and accompanying text.

108 Arnold, Market Socialism, supra note 11, at 536.

${ }^{109} \mathrm{Id}$. at 539.

${ }^{110}$ For example, see the discussions of the different managerial structures of the plywood cooperatives and Mondragón in Dow, supra note 7, at 53, 58-59.

111 ARNOLD, PHILOSOPHY AND ECONOMICS, supra note 11, at 98.

112 Id. at 109.

${ }^{113}$ Id. (citing Yoram Barzel, The Entrepreneur's Reward for Self-Policing, 25 ECON. INQUIRY 103 (1987)); Amold, Market Socialism, supra note 11, at 537 (same). 
someone else's money and if their reward depended on the further judgment of another monitor. ${ }^{114}$ The market is the capitalists' monitor. ${ }^{115}$

As Arnold acknowledges, cooperators-worker-owners of labor-managed firms-are also residual claimants and must bear the wealth consequences of their decisions. ${ }^{116}$ But first, he says, these consequences are more dispersed, especially in larger firms. ${ }^{117}$ Cooperators are fractional rather than full residual claimants, ${ }^{118}$ so the public goods problem, the incentive to shirk or act opportunistically, remains. ${ }^{119}$ Second, democratic accountability will tend to produce popular rather than effective managers, so shirking and opportunism will be more prevalent. ${ }^{120}$

This set of superficially plausible arguments faces at least three crucial difficulties. ${ }^{121}$ First, cooperative management is no less effective at monitoring, and may be more so, than capitalist organization. Labor management is just as, if not more, productive than capital management. ${ }^{122}$ Second, the problems that Arnold attributes to the cooperative form vis-á-vis the classic capitalist firm appear as or more severe in the open corporation, which has flourished in modern market economies, albeit without displacing the classic capitalist firm. Third, Arnold's explanation comes at the wrong stage, explaining (if it does) why cooperatives fail in market competition with traditional capitalist firms rather than why so few of them are formed at all.

The first point concerns the facts about the relative monitoring efficiencies of traditional capitalist enterprises versus cooperatives. ${ }^{123}$ Here, for reasons that Mill identified long ago, cooperators have a strong incentive to monitor each other. ${ }^{124}$ The evidence is that they do so effectively. Shirking is

114 Arnold, Market Socialism, supra note 11, at 537.

115 Id. at 537-38; see also, e.g., 1 MARX, CAPITAL, supra note 25, at 381 ("Under free competition, the immanent laws of capitalist production confront the individual capitalist as a coercive force external to him.").

${ }^{116}$ Arnold, Market Socialism, supra note 11, at 538.

$117 \mathrm{Id}$.

$118 \mathrm{Id}$

119 Id.

${ }^{120}$ Id. at $538-39$.

${ }^{121}$ Arnold admits these are "hypothetical rational choice explanations," ARNOLD, PHILOSOPHY AND ECONOMICS, supra note 11, at 109, and not genetic or historical explanations, id. at 110 . However, my own collective action-public goods explanation, inspired by OLSON, supra note 14, is an explanation of the same sort, so, until I deliver on the empirical evidence that I believe supports and complements the public goods explanation, I am in no position to criticize Arnold on this point.

122 See supra Part II.B.1.

${ }^{123}$ Cooperatives and participatory organizational forms in general are more productive and efficient than nonparticipatory capitalist firms. See Schwartz, supra note 2 (manuscript at Part II.C); supra Part III.B.1.

${ }^{124}$ See MILL, supra note 4, at 778 ("Their rules of discipline, instead of being more lax, are stricter than those of ordinary workshops."). It would give workers an interest in "do[ing] the utmost, instead of the least possible, in exchange for their remuneration," id. at 789 , 
not an "important problem" in labor-managed firms: "Almost all reports emphasize the prevalence of mutual monitoring and relatively low levels of formal supervision." 125 As Hansmann says, "employee ownership also gives each employee an incentive to monitor her fellow employees and to apply pressure on them not to shirk, an incentive largely lacking in an investor-owned firm."126 Arnold's shirking/opportunism explanation is an a priori prediction of a nonproblem. It essentially does not occur in labor-managed firms, and whatever monitoring issues there may be do not diminish the productivity and other advantages of labor management.

The second point is that the shirking/opportunism explanation proves too much. Similar transactions costs concerns also apply to the open corporation, which has assumed a central and commanding role in economic production in market societies. In general, the shirking argument for the greater efficiency of the classic capitalist firm should apply with more force to open corporations than to cooperatives. If it fails against corporations, it should fail against cooperatives. If shirking explained the rarity of labor management, one would expect the distribution of organizational forms in the economy to be one in which cooperatives competed with classic capitalist ones while the open corporation was a fairly marginal form-perhaps as marginal as the producer cooperative is today. Needless to say, that is not the pattern we observe.

Until the last decades of the nineteenth century, the entrepreneurial or classic capitalist firm accounted for almost all nonagricultural production, ${ }^{127}$ but, by 1985 , the top 200 corporations owned over $60 \%$ of all U.S. manufacturing assets. ${ }^{128}$ In 1984 , the top 500 corporations' sales and profits

since discipline would be "self-imposed, for the manifest good of the community[] and not for the convenience of an employer ... having an opposite interest," id. at 778-79.

125 Dow, supra note 7, at 183 (citing studies).

126 See, e.g., HANSMANN, ENTERPRISE, supra note 2, at 70; see also BRADLEY \& GELB, supra note 18, at 115 (discussing management and mutual monitoring in Mondragón). Arnold himself acknowledges that management monitoring in Mondragón is "quite effective." Arnold, Market Socialism, supra note 11, at 540. If absenteeism is a measure of shirking, in the Mondragón cooperatives, it runs at roughly half the rate of capitalist firms. See THOMAS \& LOGAN, supra note 16, at 49-52. Greenberg, after asking how "this complex production process" with more than 150 people on a shift is coordinated without close supervision, analyzes the "two-way, open, and relatively freewheeling" communication between managers and workers in the plywood cooperatives and states that the answer that "cropped up in every one of our interviews" was that "[t]he shareholders individually manage themselves and each other .... If . . some members are not contributing ... groups of worker-shareholders will tend to act as collective supervisors on the job." GREENBERG, supra note 40, at 48-49. Daniel Gavron, the leading student of the crises in the kibbutz, does not mention monitoring as a problem. In fact, he says the kibbutziks, far from showing "an avoidance of effort and a lack of initiative," created a "productive society" in the kibbutz. GAVRON, supra note 16 , at 155 .

${ }^{127}$ Richard EDWARDS, CONTESTED TERraIN: THE TRANSFORMation OF THE WORKPLACE IN THE TWENTIETH CENTURY 24 (1979).

128 "From 1954-1979, the share of GNP represented by the Fortune 500, the 500 largest companies in the United States, grew from 37\% to 58\%." William J. Murphy, Proposal for a 
accounted for about half the GNP. ${ }^{129}$ At the turn of the twenty-first century, while corporations comprised only $20 \%$ of U.S. businesses, they accounted for $85 \%$ of U.S. business revenues; globally, the largest 1000 corporations produced about four-fifths of the world's output. ${ }^{130}$ There is some overlap between open corporations and classic capitalist firms: almost $40 \%$ of publicly traded Fortune 500 companies are in some sense "family" corporations ${ }^{131}$ and, thus, could be regarded as at least quasi-classical. Moreover, the classic capitalist firm remains a lively and substantial economic presence. ${ }^{132}$

The investor-owned open corporation run by managerial employees and overseen by a board is nonetheless a towering presence. It is hardly likely to wither away. But the open corporation shares with the labor-managed firm the key features that, according to Arnold, should put both at a competitive disadvantage with respect to classic capitalist firms. In fact, as the following considerations show, the situation with the open corporation should be, in theory, far worse. The shareholder-owners-the investors-in the open corporation have little if any say in enterprise management. "[S]hareholder voting has very little to do with corporate decisionmaking.... The vast majority of corporate decisions ... are made by the board of directors acting alone, or by persons [managers] to whom the board has properly delegated authority." 133 Moreover, the managers themselves are at best only fractional

Centralized and Integrated Registry for Security Interests in Intellectual Property, 41 IDEA 297, 301 (2002); see also Roger L. Torneden, Will Devaluation of the Dollar Pull the U.S. Out of Depression Once Again?, 15 NEXUS 67, 71 (2009-2010) (estimating that 40\% of the United States' GNP comes from Fortune 500 companies).

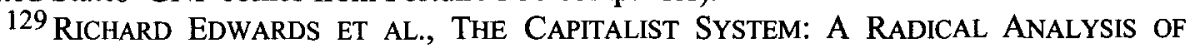
AMERICAN SOCIETY 74-75 (3d ed. 1986) (estimating almost half the GNP).

${ }^{130}$ Samuel Bowles et al., Understanding Capitalism: Competition, Command, AND CHANGE 235 (3d ed. 2005).

${ }^{131}$ See Belen Villalonga \& Raphael Amit, How Do Family Ownership, Control and Management Affect Firm Value?, 80 J. FIN. ECON. 385, 390, 394-95 (2006) (defining the family firm as one in which the founder, or a member of his family, is an officer, a director, or the $5 \%$ equity owner). On this definition, $37 \%$ of all Fortune 500 firms are family firms. See id. at 394; see also Michael V. Bourland, Implementation and Documentation of the Succession Plan, in ESTATE PlANNING FOR THE FAMILY BUSINESS OWNER 689, 692 (ALIABA 2006) (stating that at least " $1 / 3$ of Fortune 500 companies are family businesses").

132 Richard Saliterman, Perceptions Bearing on the Public Policy Dynamics of Corporation Law, 20 HAMLINE L. REV. 261, 264-65 (1996) ("Small business corporations defined as firms with under 500 employees contributed forty-eight percent of nonfarm United States employment and thirty-eight percent of the G.N.P. ..."); see also Murphy, supra note 128 (discussing the growth since 1979 of the new entrepreneurial economy as an increasing source of jobs and private wealth vis-á-vis the classic open corporation).

133 Bainbridge, supra note 21 , at 603 . This is a legal requirement as well as a sociological fact. Delaware law stipulates that a corporation's business and affairs are "managed by or under the direction of a board of directors." DEL. CODE ANN. tit. 8, § 141(a) (2001). "Shareholders have virtually no right to initiate corporate action and, moreover, are entitled to approve or disapprove only a very few board actions." Bainbridge, supra note 21 , at 603. Delaware law is important because it practically defines U.S. corporate law. "More 
residual claimants-they are, in fact, employees. ${ }^{134}$ The monitoring of managers in the open corporation devolves ultimately on the board of directors. Despite the principal-agent problems, transactions costs, moral hazard issues, and related difficulties generated by the open corporation, two centuries of history show that this organizational structure can compete highly effectively with the classic capitalist firm in many contexts.

This, however, only amplifies the puzzle. The labor-managed firm is structured more like the classic capitalist firm than its far more successful rival, the open corporation. Like the owner of the classic capitalist firm, the workerowners of the fully labor-managed and -owned enterprise exercise a great degree of more or less direct control over enterprise policy. ${ }^{135}$ Cooperative members generally practice effective mutual monitoring and monitoring of

than 850,000 entities, including over half of all U.S. publicly traded companies and over 60 percent of the Fortune 500 companies, are organized under Delaware law." Lawrence A. Hamermesh, The Challenge to Delaware's Preeminence in Corporate Law, DEL. LAW., Fall 2009 , at 8,8 .

${ }^{134}$ See HERMAN, supra note 21, at 244 (noting the decline in direct control since 1900 and the "increase in direct control by managers who own relatively little stock and yet possess considerable decision-making authority"). To acknowledge this is not to endorse the "managerialist" thesis of Berle and Means, according to which the "managerial revolution" has stripped private property of significance and left corporations in the hands of neutral technocrats who do not much care about profitability. BERLE \& MEANS, supra note 21, at 346-47; cf. HERMAN, supra note 21 , at 257-64 (remarking on the lack of theoretical and empirical support for managerial discretion to depart from the profit motive); MAURICE ZEITLIN, THE LARge CORPORATION AND CONTEMPORARY ClASSES 37, 156-61 (1989).

A better account is Alfred Chandler's classical analysis of the "ascendency of the manager" as a trained cadre of specialist employees who decided "prices, output, deliveries, wages, and employment," relegating the representatives of the entrepreneurial family founders of the large open corporations, especially in subsequent generations, to an "essentially negative" role due to their general lack of requisite knowledge and experience. Alfred D. Chandler, JR., The Visible Hand: THE Managerial Revolution in AMERICAN BUSINESS 490-91 (1977). Chandler further notes that in the large open corporation, "members of the entrepreneurial family rarely became active in top management unless they themselves were trained as professional managers." Id. at 491. Chandler's thesis, which largely concerns the fate of successful publicly traded firms, is consistent with family ownership and with first generation entrepreneurial capitalism. See id. at 9-10. Chandler entertains no illusions about the disappearance of private property, the profit motive, or the competitive pressures that, as Alchian insists, select for profitmaximizing behavior in competitive capitalism. Professional career managers, he says, "preferred policies that favored ... long-term stability and growth ... to . . maximiz[ation of] current profits," because this "was essential to their lifetime careers." Id. at 10; see also infra note 209 (discussing managerial parasitism and rent-seeking behavior). But he does not maintain that their employers abandoned the profit motive. See, e.g., CHANDLER, supra, at 473-74 (discussing how industrial managerial firms balanced "[t]he conflicting goals of maintaining current profits and assuring long-term organizational stability" and nonetheless continued to make profits even during the Great Depression).

${ }^{135}$ See Dow, supra note 7, at 52-64 (discussing how the workers in the plywood cooperatives and Mondragón exercised real, if in the case of Mondragón, decreasing, control over enterprise decisions). 
management. ${ }^{136}$ The institutions in the cooperative that correspond to the corporate board have a more varied structure and go by a variety of names. ${ }^{137}$ Terminology aside, we might expect the labor-managed firm to perform better than the open corporation because the members and their boards or assemblies are typically far more substantial residual claimants ${ }^{138}$ than the typical corporate board member, if perhaps not as much as the owner of the classic capitalist firm, who has full residual claimant status. ${ }^{139}$ Corporate boards tend to lack the owner's residual interest, whether of the classic capitalist or the cooperative member, in a responsible position of oversight. ${ }^{140}$ Yet the open corporation is

${ }^{136}$ See supra notes 125-26 and accompanying text.

137 GREENBERG, supra note 40 , at 32-33. The plywood cooperatives unimaginatively called their governing body the "board of directors," which operated under the control of an annual general membership meeting of all shareholders, i.e., cooperative workers, but under somewhat tighter formal control than the board of an open corporation. Id. Mondragón, an association of cooperatives that constitutes, in a sense, a single enterprise, has developed, since the reforms of the $1980 \mathrm{~s}$, a complex governing structure that is "challeng[ing] to present ... graphically, since [its components] do not form a typical pyramid or a flowchart, but are more like a dynamic web of shifting nodes..., [in which] the levels [are] always interacting." MORRISON, supra note 74, at 16-17. Under Spanish law, ordinary corporate law does not apply to cooperatives, which vest ultimate power, like the plywood co-ops, in an annual general assembly of all owner-workers, which then selects a governing council and a social council responsible for hiring senior management, implementing policy set by the general assembly, and deciding shop floor issues, while the managers and co-op officers have an advisory management council corresponding roughly to the management of a capitalist firm. Id. at 17-18. Other variations could exist.

${ }^{138}$ See, e.g., Arnold, Market Socialism, supra note 11, at 540 (noting that Mondragón's monitoring both vertically by management and horizontally by fellow employee is "quite effective").

139 Id. at 539.

${ }^{140}$ See Elizabeth Cosenza, The Holy Grail of Corporate Governance: Independence or Democracy?, 2007 BYU L. REV. 1, 25 ("Many independent directors own small amounts of their company's shares and receive compensation instead through large cash payments. The stakes of independent directors in the enterprises they oversee therefore do not reflect 'the performance-based concerns of ownership, but rather the interests of ... highly salaried company employee[s]." (citing Charles M. Elson, Director Compensation and the Management-Captured Board-The History of a Symptom and a Cure, 50 SMU L. REV. 127, 164 (1996))); Lynne L. Dallas, Proposals for Reform of Corporate Boards of Directors: The Dual Board and Board Ombudsperson, 54 WASH. \& LEE L. REV. 91, 140 (1997) (stating that over two-thirds of boards of large American industrial corporations are composed of outside directors); see also Sanjai Bhagat \& Bernard Black, The Uncertain Relationship Between Board Composition and Firm Performance, 54 BUS. LAW. 92 1, 945 (1999) (stating that the median firm in 1991 had an eleven-member board and three insider directors, dropping to two insiders in 1997). Insider directors are high-level employees. See Cosenza, supra, at 23. "In 2009, half of S\&P 500 companies had only one inside director, the CEO." Lisa M. Fairfax, The Uneasy Case for the Inside Director, 96 IOWA L. REv. 127, 136 (2010). Fairfax notes that this shift to outside directors represents a change from the conditions present from the 1930 s to the 1950 s, when inside directors held some $50 \%$ of board seats. Id. at 135. Non-CEO inside directors face a classic conflict of interest "because they are unlikely to contradict the CEO who is their work boss." Thuy-Nga T. Vo, To Be or Not to Be 
vastly more pervasive than the labor-managed firm in any form. This strongly suggests that whatever the explanation for the pattern of organizational forms, different incentives to shirk due to different degrees of ownership is not the explanation.

Arnold concedes that "shareholders in the open corporation face the same problem[s]" with monitoring and opportunism. ${ }^{141}$ In his piece Market Socialism, Arnold puts the point quite forcefully, but then retreats to a comparison of "opportunities for exploitation"-roughly the effect of opportunism on the other workers and society- "in a market socialist system that are not found in the open corporation under capitalism."142 In his expanded book-length treatment, Arnold attempts to come to terms with the implications of his admission that the open corporation is at a disadvantage with respect to the cooperative on the monitoring issue on which he says the cooperative is at a disadvantage with the classic capitalist firm. ${ }^{143}$ Arnold gives an extended discussion in broadly Coasean terms of various real and supposed transactions cost efficiencies of the open corporation. Vertical integration brings decision making and asset ownership under a single roof rather than requiring coordination in acquisition and use of specialized assets through short term contracts. Thus, fewer resources need be expended to protect against potential opportunism by input providers and customers, ${ }^{144}$ and the supposed joining of ultimate decision-making authority to residual claimant status of shareholders improves monitoring, thus efficiency. ${ }^{145}$

But Coase's account of the firm-market boundary is silent on the internal structure on the firm. ${ }^{146}$ Some of the efficiencies Arnold invokes are illusoryshareholders have little or no power in large open corporations, ${ }^{147}$ and the shirking/opportunism problem pervades the open corporation because of the separation of ownership and control. ${ }^{148}$ Arnold invokes the power of the board of directors in monitoring the management. ${ }^{149}$ As noted, however, corporate

Both CEO and Board Chair, 76 BROOK. L. REV. 65, 85 n.116(2010) (citing Sydney Finkelstein \& Richard A. D'Aveni, CEO Duality as a Double-Edged Sword: How Boards of Directors Balance Entrenchment Avoidance and Unity of Command, 37 ACAD. MGMT. J. 1079, 1102 (1994)).

141 Arnold, Market Socialism, supra note 11, at 546.

142 Id. at 547. Market socialism, to be fair, is Arnold's official topic; the labor-managed firm and economy (my own topic), which would result if most enterprises were labor-owned and -managed, is not a socialist system.

143 ARNOLD, PHILOSOPHY AND ECONOMICS, supra note 11, at 126-53.

${ }^{144}$ Id. at 138 .

$145 \mathrm{Id}$. at 142 .

146 See generally Coase, supra note 100 and accompanying text.

147 See supra notes $133-34$ and accompanying text.

148 ARNOLD, PHILOSOPHY AND ECONOMICS, supra note 11, at 147.

${ }^{149} \mathrm{Id}$. at 148-49. In his book-length analysis, Arnold takes a classical rather than a Biblical turn and invokes Juvenal's slogan, "Quis custodiet ipsos custodes?"-Who watches the watchers? Id. at 108 (quoting JUVENAL, SATIRES VI: $347-48$ ). 
boards typically lack significant shareholder residual interest ${ }^{150}$ and involve grave principal-agent and moral hazard costs in the absence of effective shareholder power. ${ }^{151}$ His ultimate reply is that the market will handle the monitoring problem with the aid of securities analysts. ${ }^{152}$ This is a sadly misplaced faith. Even more to the point here, it does not go to the comparison with cooperatives, where the equity owners exercise direct control like classic capitalists and, like them, similarly face the pressures of the market. A noncomparative answer is no real explanation at all. ${ }^{153}$

The third problem with Arnold's explanation is that it enters too late. The mechanisms that Arnold identifies might explain why labor-managed firms failed at a higher rate than capital-managed firms of any type, if he had identified real relative inefficiencies-and if labor-managed firms failed at a higher rate than capital-managed ones. ${ }^{154}$ In both cases, the purported greater inefficiencies that Arnold claims are due to monitoring costs do not hold for the cooperative against either the classic capitalist firm or the open corporation. But even if they did, the problems would emerge only once a labor-managed firm had been created and was in competition with capital-managed rivals. The specific transactions costs Arnold identifies would not, even if valid, explain why labor-managed firms are so rarely created relative to their capitalist rivals.

${ }^{150}$ See supra notes 133,140 and accompanying text.

151 ARNOLD, PHILOSOPHY AND ECONOMICS, supra note 11, at 149-50 ("The principalagent relationship between the board and the equity owners is itself in need of monitoring.").

${ }^{152} \mathrm{Id}$. at 150 . This claim shows a certain naiveté about the way the securities analysis business operates. These are, after all, the people who told us that Enron set " [ $[t]$ he industry standard for excellence." See BETHANY MCLEAN \& PETER ELKIND, THE SMARTEST GUYS IN THE ROOM: THE AMAZING RISE AND SCANDALOUS FALL OF ENRON 229 (updated ed. 2004) (quoting Edward Tirello, a Deutsche Bank securities analyst, among others). "The modern analyst ... was more a marketer than a researcher and was almost entirely consumed by short-term considerations." Id. at 231 . And the analysts were very much for sale. "There was simply too much investment-banking business at stake not to have a screaming buy on [bad] stock [like Enron]." Id. at 233. "Since research units were now directly generating revenue, rather than providing 'objective' analysis, ... analysts pushed stocks despite knowledge of balance-sheet fraud and bubble marketing." KAREN HO, LIQUIDATED: AN ETHNOGRAPHY OF WALL STREET 78 (2009). Lest it be thought that the Sarbanes-Oxley Act, 15 U.S.C. $\S \S 7201-$ 7266 (2006), has restored integrity to the business, we need only contemplate the meltdown of 2008, in the aftermath of which we are still living at this writing.

${ }^{153}$ Ironically, it is a considerable virtue of Arnold's approach to comparing and critiquing social arrangements to insist, in general, on such comparisons. See, e.g., N. SCOTT ARnOld, MarX's Radical CRITIQUe of Capitalist Society: A ReCONSTRUCtion and CRITICAL EVAluation 3-27 (1990) (arguing that a critic must show that some proposed alternative social arrangement or organizational structure avoids whatever vices have been attributed to the status quo). There, Arnold compares socialism and capitalism, but the point applies equally to comparison of labor-managed and capital-managed enterprises.

${ }^{154}$ Neither the empirical evidence or (at least with respect to the open corporation) the theoretical transactions cost analyses support Arnold's claims about the relative inefficiency or implicit prediction of a higher failure rate of the labor-managed firm compared to the classic capitalist firm or open corporation. See supra notes 49-50 and accompanying text. 
Recall Alchian's caveat that the comparative efficiency of different "patterns of behavior and organization are predictable ... if they are tried."155 And this is the central puzzle: "The main problem[] for [labor-managed firms is] that they are rarely created ...."156 These patterns of behavior and organization are not tried.

In view of the theoretical and empirical arguments for the efficiency advantages of labor management vis-á-vis traditional capitalist organization, any explanation of why this form of organization is rare must start here. Alchian's second caveat, that nothing succeeds like success because successful models will be imitated, ${ }^{157}$ simply poses the same problem over again. Why are there not countless thriving labor-managed firms to inspire the sincerest form of flattery? Arnold's specific transactions cost arguments cannot explain why labor-managed firms are not formed at any significant rate to succeed or fail in whatever ratios to their capital-managed competitors in the first place. Hence, I turn to the very different transactions cost analysis of Henry Hansmann, who starts by conceding practically all the advantages that Arnold would deny to the labor-managed firm.

\section{Hansmann: Homogeneity and the Costs of Collective Decision Making}

Hansmann's exceptionally lucid, although somewhat idiosyncratic, survey of common but inadequate explanations for the rarity of the labor-managed firm is only one of the many merits of his indispensable study. ${ }^{158}$ One could hardly ask for a better statement of the problem I address in this Article than Hansmann's summary:

[E]mployee ownership holds the promise of significant efficiency advantages, including... avoidance of opportunism ..., less strategic behavior in bargaining, better communication of employee preferences, and reduction in worker alienation. These advantages presumably explain the success of employee ownership in those industries where it is commonly found. But the magnitude of the potential efficiency gains from these sources correlates poorly with the actual pattern of employee ownership. In general, these

155 Alchian, supra note 9, at 220.

${ }^{156}$ Dow, supra note 7 , at 125 . With respect to Arnold's own official target, market socialism, whether it would be macro-economically more or less efficient cannot bear on why it does not develop "in the womb" of capitalism, since the macro-(in)efficiencies would only emerge when that system was already in place.

157 Alchian, supra note 9 , at 217-20.

${ }^{158}$ HANSMANN, ENTERPRISE, supra note 2, at 66-88. A particularly valuable aspect of his study, not relevant to my discussion here but worth remarking upon, is his extended exploration of the patterns of different types of existing cooperative ownership. See id. at 120-286 (spanning chapters 7-14). 
potential gains seem greatest in large-scale hierarchical firms, which are typically investor-owned . . . 159

Hansmann, then, denies Arnold's claim that employee ownership is inherently less efficient than investor ownership. Its efficiency, he thinks, varies inversely with the degree of what he calls the "homogeneity" of the firm, especially as to the related issues of compensation and job function. ${ }^{160}$ His proposed explanation is that "the costs associated with collective decision making" explain much of the existing pattern of employee ownership and determine where it is viable. ${ }^{161}$ While the employees are generally better situated to oversee management effectively, they "are far more likely than investors to differ among themselves concerning the firm's policies." 162 Employee-owned firms are scarce where "there are substantial differences among the employees who participate in ownership. Most typically, employeeowners all do extremely similar work and are of essentially equivalent status within the firm."163 Employee ownership "works best when there is little opportunity for conflict of interest among the employee-owners" and "is viable when the employees involved all play a similar role within the firm," 164 like the plywood co-ops. ${ }^{165}$ Hansmann thinks that the greatest source of contention is dispute about the fairness of unequal compensation in enterprises with differentiated roles. 166

Hansmann's explanation faces three problems. First, he treats homogeneity, so understood, as exogenous rather than as a result of choices about firm governance that the employee-owners adopt, in some cases quite clearly in order to reduce conflict. Rather than explaining why employee ownership is not more prevalent, therefore, Hansmann in effect raises the further question of why

${ }^{159} \mathrm{Id}$. at 74-75. Hansmann uses the terms "employee-owned" and "investor-owned," id. at 74-75, where 1 have used Dow's terms "labor-managed" and "capital-managed," Dow, supra note 7, at 5, for reasons explained. In this section, however, I largely use Hansmann's terminology. The ellipses omit Hansmann's statement that employee ownership is most common in professional service firms. HANSMANN, ENTERPRISE, supra note 2, at 75. I have explained my skepticism about Hansmann's treatment of enterprises such as large law firms as invòlving genuine employee ownership, id. at 67 (stating that such partnerships are "among the world's purest examples of employee ownership"), or at least employee ownership of the sort that interested Mill and most students of the topic. See supra note 66.

160 HANSMANN, ENTERPRISE, supra note 2, at 98.

161 Id. at 91.

162 Id. at $89-90$.

${ }^{163} \mathrm{Id}$. at 91.

${ }^{164} \mathrm{Id}$. at 92 .

${ }^{165}$ Hansmann also offers the examples of the law firm partnership, which, as noted, he takes to be a relevant sort of employee ownership, and "[ $t]$ he driver-owned transportation cooperatives that are so common throughout the world." Id. at 91-92.

166 RAYMOND RUSSELL, SHARING OWNERSHIP IN THE WORKPLACE 181 (1985) (arguing that in three different types of employee-owned firms, "[t]he politics of sharing income appears to be the most volatile issue," requiring consensus "that the existing compensation system is fair"), quoted in HANSMANN, ENTERPRISE, supra note 2, at 319 n.5. 
there are not more enterprises in which employee-owners have chosen appropriately conflict-minimizing rules and policies. Second, Hansmann's account, like Arnold's, fails to explain why open corporations do not face the problems he attributes to employee-owned firms. This problem is thrown into relief by Hansmann's treatment of Mondragón, the obvious counterexample to his homogeneity thesis. Third, insofar as Hansmann's theory is an account of why so few employee-owned enterprises are started, it also comes in too late, and again to explain a non-phenomenon. There is no plethora of less productive employee-owned firms riven by conflict that fail at a higher rate than investorowned firms. The rarity with which employees even attempt to establish producer cooperatives is the primary puzzle.

Hansmann is right that collective decision making is costly. Conflicts among persons engaged in productive activity, and therefore the transactions costs of attaining agreement on what to do and how to do it, are likely to diminish efficiency. ${ }^{167}$ "[H]omogeneity of interest," Hansmann says, is "a social construct"168 limited by culture and institutions, ${ }^{169}$ such that "what passes for homogeneity in one setting may not in another."170 The only concrete sorts of homogeneity that he discusses, however, are egalitarian compensation and the functional division of labor where, as in the plywood cooperatives, "all workers have essentially the same role within the firm."171 Employee-owned

${ }^{167}$ I express this in a qualified way because homogeneity of interest and lack of conflict are not necessarily unmitigated efficiency advantages. I do not wish to minimize the inefficiencies due to nonconflictual agreement on bad ideas based in "groupthink." See IRVING L. JANis, Groupthink: Psychological Studies of Policy Decisions and FiASCOES 9 (2d ed., rev. 1983) (defining groupthink as "a mode of thinking that people engage in when they are deeply involved in a cohesive in-group, when the members' strivings for unanimity override their motivation to realistically appraise alternative courses of action"); Robert S. Baron, So Right It's Wrong: Groupthink and the Ubiquitous Nature of Polarized Group Decision Making, in 37 ADVANCES IN EXPERIMENTAL SOCIAL PSYCHOLOGY 219 passim (Mark P. Zanna ed., 2005); Marleen A. O'Connor, The Enron Board: The Perils of Groupthink, 71 U. CIN. L. REV. 1233, 1309 (2003). As Mill emphasized, free discussion, lively criticism, and a diversity of perspectives are not only valuable in themselves, but are also the surest means to forming reliable and true beliefs. MILL, supra note 29, at 146.

${ }^{168}$ HANSMANN, ENTERPRISE, supra note 2, at 98. Thus, it was once legally acceptable in the United States to pay people of different colors, races, or sexes different wages for the same work. Id.

${ }^{169} \mathrm{Id}$. The problem is not especially tractable. See Martha Minow, Not Only for Myself: Identity, Politics, and Law, 75 OR. L. REV. 647, 657-58 (1996) ("The persistent failure of group-based categories to yield consistent applications hints at the defects in their boundaries, their origins, their applications, and their ultimate meaningfulness. The coherence [of group identities] is further challenged, though not automatically undermined, by historically shifting boundaries."). There is a reason that Marx's discussion of "What makes a class?" breaks off without an answer after thirty-seven lines. See 3 MARX, CAPITAL, supra note 18 , at $1025-26$.

${ }^{170}$ HANSMANN, ENTERPRISE, supra note 2, at 98.

${ }^{171} \mathrm{Id}$. A richer notion of homogeneity, encompassing culture, tradition, language, religion, and perhaps political ideology, unfortunately would not strengthen an explanation 
firms tend to have lower or even virtually no pay differentials, 172 and sometimes the firms involve a less differentiated set of tasks than one finds in typical investor-owned firms. ${ }^{173}$ Hansmann may overstate the importance of an undifferentiated division of labor. Mondragón, for example, is not designed to promote functional similarity, something to which I return. Supposing for the sake of argument, however, that a relatively high degree of functional similarity in kinds of work is as important as Hansmann claims, giving workers essentially the same roles is nonetheless possible even with highly articulated kinds of production. This is illustrated by job rotation in auto manufacture. The former GM-Saturn contract and Volvo production methods involved investor-owned firms, but these methods also show that complex tasks can be designed to be done under conditions of functional similarity. ${ }^{174}$

Hansmann might be correct about the circumstances under which cooperatives flourish, but he might be incorrect about why those circumstances occur when they do. The first problem with the homogeneity account is that Hansmann treats egalitarian policies in compensation and similarity of job function as something given rather than chosen. That is, by analyzing homogeneity as a mere condition of successful employee ownership, he

of this sort. A common Basque culture and heritage may have played some part in Mondragón's success. See, e.g., KASMIR, supra note 51, passim (discussing commonalities and conflicts in Basque working class culture and history and their role in Mondragón's development); see also infra Part IV.B (discussing the role of the community in the initial financing of Mondragón). But, as Kasmir underlines, people with a common cultural heritage are not always in harmony. See KASMIR, supra note 51, at 91-120 (discussing political conflicts between nationalism and socialist politics in the town of Mondragon in the context of the 1974 strike at the founding cooperative, Ulgor, "remember[ed] . . . as one of the most divisive events in recent [local] history"). Spain itself offers within living memory a spectacular instance of how people with a broadly common cultural heritage can generate conflicts, in that instance, primarily political and ideological, so severe that they degenerate into war.

${ }^{172}$ The employee-owners of cooperative enterprise must make potentially divisive decisions about compensation even with a flat pay scale-for example, whether to maintain compensation at current levels in economic difficulty at the cost of having to reduce employment by buying out members or, in better times, whether to increase their own compensation at the risk of foregoing investment and savings. Similar questions must be faced by the management, and ratified by the owners or their representatives on the board, of traditional or even participatory capitalist firms.

173 See, e.g., Dow, supra note 7, at 53; HANSMANN, ENTERPRISE, supra note 2, at 92.

174 See, e.g., CYNTHIA ESTLUND, WORKING TOGETHER: HOW WORKPLACE BONDS STRENGTHEN A DIVERSE DEMOCRACY 55 (2003) (discussing how, in Saturn plants, "[i]n place of rigid job descriptions, there [was] a single production worker classification," production involved "job rotation," and workers performed "a variety of job tasks in their work area" as well as "some of the planning and control tasks traditionally carried out by supervisors"). See generally KaJSA ElLEGARD ET AL., REFORMING INDUSTRIAL WORK:

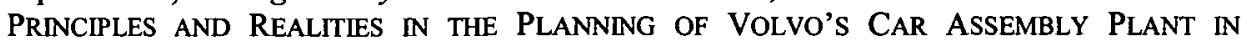
UDDEVALLA (1991) (similar). I cite these now-ended experiments solely to make this point and not to hold either program up as an ideal. For more on Saturn, see Schwartz, supra note 2 (manuscript at $15 \mathrm{n} .95$ ). 
presents it as something with which employees somehow find themselves, rather than as an organizational choice they adopt in order to minimize conflict, or which has that effect-a decision that they make. Compensation and division of labor in a firm are not exogenous variables. In some cases, like plywood cooperatives, avoidance of conflict is an expressly stated rationale for flat or relatively flat pay scales. ${ }^{175}$ Hansmann does indeed consider whether the "causation runs the other way... [that] employee-owned firms may be unusually inclined to adopt egalitarian practices simply because they are employee-owned, and not because such practices are necessary to reduce governance costs." $176 \mathrm{He}$ responds that the mere existence of employee ownership would not explain why it "tends to arise only where the employees involved are highly homogeneous to begin with."177 Unfortunately, these formulations highlight how Hansmann treats homogeneity as a given. His reply, therefore, is a false dilemma-if homogeneity is necessary for employee ownership, why cannot it be both a condition and a choice? So far, then, we have no reason to believe that Hansmann has correctly identified or adequately defined the dependent and independent variables or the relation between them.

The major counterexample to the claim that homogeneity is a causal condition of successful employee ownership is Mondragón, the most prosperous employee-owned enterprise in the world market. Among other things, Mondragón raises the issue of whether the open corporation's mechanisms for handling conflict are superior to the governance design that a vibrant employeeowned firm has chosen to adopt. This is the second problem with the homogeneity account in Hansmann's version. Mondragón is not homogenous with respect to the functional division of labor. It engages in different kinds of manufacture, service, and other productive activity, in which the employeeowners perform diverse kinds of tasks and occupy different roles, ${ }^{178}$ although it does have a fairly flat pay scale. ${ }^{179}$ The open corporation is often at least as heterogeneous as Mondragón and its pay scales are anything but flat. ${ }^{180}$ Hansmann offers no empirical or theoretical basis for assessing whether these sorts of differences generate less conflict in the investor-owned open corporation than in the employee-owned cooperative.

175 GREENBERG, supra note 40, at 178; HANSMANN, ENTERPRISE, supra note 2, at 92, 319 n.6. Mondragón's pay scales are also fairly egalitarian. See Dow, supra note 7, at 60,63 (stating that in Mondragón, the ratio between the lowest and highest wages was 1:3, and widened to 1:6 after 1987).

${ }^{176}$ HANSMANN, ENTERPRISE, supra note 2, at 95. Hansmann even offers evidence for this hypothesis, noting that workers at such firms will tend to accept lower pay if it is more equal, and demand higher pay if it is less so and if they are among the lowest paid. Id.

${ }^{177}$ Id.

178 See supra notes 76-82 and accompanying text.

${ }^{179}$ See supra note 51 and accompanying text.

180 The ratio of compensation of the 100 highest-paid CEOs in America to the average worker's wage was $2388: 1$ in 1998, up from 373:1 in 1988 and 49:1 in 1970. BowLES ET AL., supra note 130 , at $350-51$ fig.14.3. 
Instead, Hansmann responds to the challenge of Mondragón by attempting to remove Mondragón, in part, from the roster of employee-owned enterprises. Mondragón, he notes, uses representative democracy and restrains the extent and ways in which employees can appropriate firm earnings. ${ }^{181}$ While Hansmann does not deny that Mondragón workers do "participate meaningfully in control,"182 he argues that these restrictions and other governance structures and enterprise policies mean that in Mondragón, "workers' rights to control and ... earnings are attenuated ..., and the individual firms cannot really be said to be fully owned by their workers." 183 This amounts to saying that only direct democracy without governance or investment policies would count as "real" or "full" worker ownership and control. ${ }^{184}$ The position is quite implausible, and Hansmann does not even attempt to offer a theoretical justification for it. The logic of the argument would imply that open corporations are not "fully owned" by their investors ${ }^{185}$ because they involve minimal investor control, extensive indirect governance mechanisms, firm policies regarding investment and charitable contributions, and restrictions on what investors can do with their shares, such as rules governing different classes of stock. It would imply, for that matter, that the classic capitalist does not "fully" own his productive assets because of legal limitations on property use. ${ }^{186}$

${ }^{181}$ HANSMANN, ENTERPRISE, supra note 2, at 99-100 (asserting that electoral mechanisms are a "blunt" means of control of management and noting that Mondragón rules limit workers' choice of wage scales and require that $20 \%$ of earnings be retained for investment and $10 \%$ "devoted to educational, cultural, or charitable purposes").

$182 \mathrm{Id}$. at 102 .

$183 \mathrm{Id}$. at $101-02$.

${ }^{184}$ Further, Hansmann does not consider the possibility that the rules that he claims make Mondragón less than fully worker-owned can be altered, amended, or replaced by the Mondragón workers, and in fact, at least under law, much more easily than analogous changes could be made by investors in open corporations in the United States.

${ }^{185}$ See HANSMANN, ENTERPRISE, supra note 2, at 62-64 (discussing corporate governance rules as a means of mitigating the costs of collective decision making).

${ }^{186}$ It is no surprise that Hansmann does not articulate this essentially anarcho-syndicalist theory out loud. See, for example, Democracy, Philip Green's anthology of essays on concepts of democracy, where, despite the wide range of different democratic theories discussed, from radical to elitist, this sort of theory does not even receive an entry. DEMOCRACY (Philip Green ed., 1993). The corresponding theory of ownership would imply that any restriction on my use of my property, legal or contractual, means that I do not fully own it, is not one that is even maintained by contemporary radical libertarians. The leading libertarian thinker of the late twentieth century, Robert Nozick, defends a minimal state that ipso facto involves rules limiting the use of property. See ROBERT NozICK, ANARCHY, STATE, AND UTOPIA 88-146 (1974). Indeed, it is hard to understand how possession could count as ownership without legal rules of property, contract, and tort that define and therefore restrict the use of what is possessed. See Cass R. SUnsteIn, ThE Partial CONSTITUTION 51-59 (1993) (setting forth left-liberal arguments that unpack the implications of the fact that property rights are legal creations). See generally RICHARD A. 
But Hansmann wants it both ways. He argues that the governing mechanisms of the open corporation and the body of corporate law are "means for ... resolving the worst of these conflicts." 187 He does not consider Mondragón's governance rules as a way of, inter alia, reducing the costs of conflict and decision making in a large and diverse employee-owned enterprise. On the contrary, he contends that Mondragón's rules mean that it is not a genuine case of employee ownership, but at best an attenuated one. ${ }^{188}$ Then we would be comparing attenuated investor ownership with attenuated employee ownership. Showing that transaction costs in decision making are lower with the open corporation than with Mondragón would require some evidence or argument. It begs the question to reason from the rarity of employee ownership to more conflict and less efficient decision making. In face of the vitality and success of Mondragón, any such argument would face some uphill sledding.

Finally, Hansmann does not explain, by appeal to this sort of transaction cost, why so few cooperatives are started, because he, like Arnold, has started too late. As Alchian noted, an innovation or policy must be tried in the first place to be put to proof in the market. ${ }^{189}$ The relative costs of conflicts among diverse groups of employees regarding decisions about compensation and other matters can only be estimated where the employees have the power to make decisions, which they virtually never do. The mystery remains why the labormanaged firm is not more widely tried. If conflict over decision making due to heterogeneity is meant to explain the rarity of cooperative startups rather than, in part, their distribution in different economic sectors and activities, Hansmann fails to show it. The question remains open: Where did Mill go wrong?

\section{Transactions Costs External to the Enterprise: Dow's Capital Formation Problem}

\section{Issues of Outside Financing}

Arnold and Hansmann explain the rarity of cooperatives because of transactions costs arising inside the enterprise that are supposed to account for why cooperatives are purportedly less efficient than capitalist firms. We have noted three things about such explanations. First, whatever the specific mechanism they locate to account for comparative inefficiency, the middle term in the explanation, that cooperatives are less efficient, conflicts with the empirical evidence. Second, both sorts of explanations run ashore, logically, in accounting for the open corporation, which, on their terms, should be less efficient, and thus, in Alchian's terms, less prevalent than cooperatives. Third,

EPSTEIN, SIMPLE RULES FOR A COMPLEX WORLD (1995) (addressing property law from the libertarian perspective). In a sense, all ownership and control is a matter of degree.

${ }^{187}$ HANSMANN, ENTERPRISE, supra note 2, at 90.

188 Id. at $99-103$.

${ }^{189}$ See Alchian, supra note 9, at 219. 
both explanations arrive after the train has left the station because they presuppose problems with functioning cooperatives when the issue we face is rather why so few of them are formed to begin with.

It is a merit of Dow's account that it largely avoids these problems. Dow's full account ${ }^{190}$ is complex, multi-factored, and embedded in a deep theory about the inalienability of labor versus the alienability of capital. ${ }^{191}$ I address a somewhat limited version that sidetracks the deep theory and picks up on the strand that goes directly to the question posed in this Article, which Dow himself concedes to be the (or a) crucial issue: "The main problem[] for [labormanaged firms is] that they are rarely created ...."192 Dow's explanation turns on his claim about "the inability of workers to offer credible guarantees of repayment to [outside] investors" in labor-managed firms. ${ }^{193}$ Labor-managed firms, especially if they are capital intensive, lacking in assets, and involving economies of scale or scope, face financing problems not faced by capitalmanaged competitors. ${ }^{194}$ Dow does not attempt to explain any purported comparative internal productive inefficiencies of labor management; on the contrary, he denies at length and with evidence that they exist. ${ }^{195}$ Second, for the most part, the explanation does not involve any puzzling asymmetries between classic capitalist firms and open corporations. Finally, Dow locates the proposed explanation at the right point: "[A]ccess to financing is crucial to firm formation."196 Unlike Arnold's monitoring efficiencies theory or Hansmann's heterogeneity transactions costs account, which only kick in, if they do, once the labor-managed firm is up and running, Dow's capital formation explanation,

190 Dow, supra note 7, at 234-59.

${ }^{191}$ Id. at 234-36.

$192 \mathrm{Id}$. at 125 .

${ }^{193}$ Id. at 237. The other two "threads" in Dow's "causal tapestry," id. at 234, are, respectively, "the internal composition of control groups, especially size and degree of heterogeneity," $i d$. at 237-38, essentially Hansmann territory; "and the commodification biases that undermine [labor-managed firms]," id. at 238 , in which the inalienability of labor may lead to underinvestment, degeneration by shift to wage labor, and investor takeovers or transformations into capital-managed firms, $i d$. at 239 . Whatever the merits of or problems with Dow's spinning out these two threads, they go to comparative efficiencies of alreadyexisting labor-managed firms and their capital-managed rivals, whereas my question is why so few labor-managed firms are in fact formed.

${ }^{194}$ Id. at 237. Dow does not treat this problem as a transactions cost, restricting that term to his discussion of Hansmann, see id. at 121-26, but capital formation difficulties are classic transaction costs, if the term is extended to reach issues beyond firm boundaries-as, on a broadly Coasean approach-they should be. It was in determining why there were firm-market boundaries at all that Coase came to consider the issue of transaction costs. See supra notes $99-100$ and accompanying text.

195 Dow, supra note 7, at 240 ("'Labor-managed firms] have no evident problem with respect to labor productivity.... [The] direct comparisons with [capital-managed firms] ... are favorable to [labor-managed firms].").

196 Id. at 236. 
in accord with the King of Hearts' rule, begins at the beginning, ${ }^{197}$ with the comparative problems for forming such an enterprise as opposed to a capitalist firm.

Dow's central idea is that "[i]n capitalist firms, wealthy investors simply pool their funds and acquire physical assets,"198 while labor-managed firms, especially if they are capital intensive, "must find a way of financing . . . assets, but they often founder on the shoals of limited wealth and liquidity constraints."199 I return to the curious fact that labor-managed firms are generally self-financed. ${ }^{200}$ Here I critique Dow's arguments that "commitment" asymmetries explain why outside financing is more available for capitalmanaged than labor-managed firms.

As Dow implies, (capital-intensive) capitalist firms can be initially financed by sources other than the capitalist entrepreneur's own assets. Capitalist entrepreneurs can borrow capital from banks, sell shares, or issue bonds to raise money from the public. Why do labor-managed firms not have recourse to the same sources of capital assets? Dow frames the problem as one of offering "credible guarantees of repayment to investors." $201 \mathrm{He}$ thinks investors have more worry about being repaid by a labor-managed than a capital-managed firm. It is not obvious, however, why this should be so. If investors are economically rational, ${ }^{202}$ one would expect them to be concerned with the safety and profitability of their assets. Why would loan officers at banks, private purchasers of stocks and bonds, or other investors wish to invest in less productive, thus, by proxy, probably less profitable firms? Even if investors and

197 '“'Begin at the beginning,' the King said, very gravely, 'and go on till you come to the end: then stop."' LeWIS CarRoll, THE ANNOTATED Alice: Alice's AdventURES IN WONDERLAND \& Through THE LOOKING Glass 158 (Martin Gardner ed., Clarkson N. Potter, Inc. 1960) (1865).

${ }_{198}$ Dow, supra note 7 , at 236.

199 Id.

$200 \mathrm{Id}$. at 191; see also HANSMANN, ENTERPRISE, supra note 2, at 75-76 ("The proliferation of ESOPs in the manufacturing sector indicates that a firm's employees can themselves provide substantial equity capital without crippling costs.").

201 Dow, supra note 7 , at 237.

202 The underlying theory of economic rationality is called rational choice theory. It has been variously characterized, but on one useful summary, it includes the following claims: (1) rational behavior involves maximizing a set of preferences; (2) rational agents are egoistic, self-interested, or mutually disinterested in the welfare of others; (3) the preferences of rational agents satisfy certain sorts of consistency; (4) rational choice is choice under uncertainty, where agents maximize the expected value of their own payoffs; and it is sometimes added (5) rational choice involves the behavior of individuals rather than groups. See, e.g., Donald P. GReEn \& IAN ShaPIRo, PATHOlogies of RATIONAL Choice TheORY: A CritiQue of APPLiCATIONS IN POLITICAL SCIENCE 14-17 (1994) (characterizing the elements); RATIONAL CHOICE 1-16 (Jon Elster ed., 1986). Obviously this is a highly idealized theory, like the (related) theory of the perfectly competitive market discussed supra note 6. I return to this point in Part IV.C. 
lenders are not economically rational, ${ }^{203}$ on Alchian's quasi-Darwinian model, the market should over the long run favor behavior that, however motivated, tracks rational, profit-maximizing behavior. Investors and lenders who so act should prosper more than their rivals whose behavior is irrational. ${ }^{204}$ Imitation should amplify investment in and loans to more successful labor-managed firms. ${ }^{205}$

Dow's presentation of his capital formation explanation is uncharacteristically thin. Comparative empirical data is lacking: "There are no data comparing the cost of external capital for [capital-managed versus labormanaged firms], so it is impossible to determine directly whether [labormanaged firms] are disadvantaged in the credit market relative to similar [capital-managed firms]."206 This is a very damaging admission for Dow's account. In the absence of data, Dow turns to speculation. He says, first, that "[o]nce investors have committed ... funds or physical assets to the [labormanaged] firm, [its members] may . . . take advantage . . by paying themselves high wages, depreciating equipment rather than supplying effort, or pursuing risky projects in which investors would be left holding the bag." 207 The empirical evidence contradicts the concern that worker-owners tend to overpay themselves rather than making necessary investments. ${ }^{208}$ And Dow gives no

203 There is much evidence people are not economically rational. See generally Behavioral Law AND ECONOMICS (Cass R. Sunstein ed., 2000); Heuristics AND BIASES: The Psychology of INTUITIVE JUDGMENT (Thomas Gilovich et al. eds., 2002); JOHN H. HOLLAND ET AL., INDUCTION: PROCESSES OF INFERENCE, LEARNING, AND DISCOVERY (1986); JUDGMENT UNDER UNCERTAINTY: HEURISTICS AND BIASES (Daniel Kahneman et al. eds., 1982). I retum to this in discussing my own explanation of the rarity of labor management. See infra Part IV.C.

It is worth remarking that Milton Friedman's positivism, see generally MILTON FRIEDMAN, The Methodology of Positive Economics, in ESSAYS IN POSITIVE ECONOMICS 3 (1953), the idea that it does not matter whether the underlying theory (here, that people are economically rational) is true as long as the theory is predictive, is based on a conception of science (logical empiricism) as mere organization of observed results for predictive purposes that has been utterly discredited for almost half a century. See generally RICHARD W. Miller, FACT AND METHOD: EXPLANATION, CONFIRMATION AND REALITY IN THE NATURAL AND THE SOCIAL SCIENCES (1987) (setting forth, inter alia, the now generally accepted critique of logical empiricism).

${ }^{204}$ Alchian, supra note 9, at 213-14.

205 As Alchian noted, imitation drives much economic behavior. Id. at 217-20; see also infra note 226 (discussing evidence for the "mere exposure" or "familiarity" effect, on which the familiar is more attractive because of its familiarity-another empirically grounded behavioral irrationality).

${ }^{206}$ Dow, supra note 7, at 192.

${ }^{207}$ Id. at 237 (emphasis added).

${ }^{208}$ Thus, Mondragón's response to economic difficulty in the 1980 s was for the workers to cut wages. See MORRISON, supra note 74, at 187-88; WHYTE \& WHYTE, supra note 16 , at 182-83 (addressing the situation at a particular co-op). Morrison underlines that, in response to proposed economic sacrifices, cooperators were "reluctan[t] ... to sacrifice current income for possible long term benefit." MORRISON, supra note 74, at 196. This is not surprising, but neither is it evidence of a tendency to loot the firm at the expense of 
reason to think that any such problem for cooperatives is worse than the tendency of capitalist managers to feather their own nests at the expense of shareholders and investment. ${ }^{209}$

Speaking of raising capital by sales of nonvoting shares, Dow states without evidence that labor-managed firms might take more advantage of outside investors than capitalist firms: "[T]here is no reason why dividends would ever be paid, apart from the firm's concern for its reputation or its need for further capital later." 210 But these are weighty incentives to keep the investors happy. Moreover, it is unclear from Dow's presentation or anything in economic theory or behavioral psychology why the same considerations do not apply with equal force to capitalist firms. Dow dismisses the force of a lender's threat to refuse to extend further credit to a deadbeat, ${ }^{211}$ but offers no plausible argument that labor-managed firms are at all likely, much less more likely, to stick it to creditors than are capitalist firms. Why should they engage in such selfdestructive and counterproductive conduct as a matter of course? Dow raises the speculative worry that, with regard to bank loans, the borrower may pursue "risky projects with high upside potential," 212 without giving any evidence that this occurs. He leaves out a crucial comparison when he ignores the capitalist financiers' own astounding appetite for risk, which lenders and investors tolerate and encourage. "The very structure of Wall Street," states anthropologist Karen Ho, "encourages the milking of the present and a strategy of ... [bad investments], more for the purpose of generating [short-term] profit than protecting against risk." 213

necessary investments. Ward argued that economic theory predicts, if anything, overinvestment in capital. See WARD, supra note 8 , at 210-12. The evidence on this is mixed. See Dow, supra note 7, at 190 (citing studies that labor-managed firms have lower capital-labor ratios than their capital-managed competitors and suggesting that Mondragón's cooperative bank explains that anomalous case); THOMAS \& LOGAN, supra note 16 , at 136 (supporting this in the case of Mondragón).

${ }^{209}$ See the (in)famously eloquent condemnation of capitalist management parasitism by the fictional Gordon Gekko (modeled on 1980s corporate raider Michael Milken) in Oliver Stone's Wall Street, where Gekko denounces "these bureaucrats, with their steak lunches, their hunting and fishing trips, their corporate jets and golden parachutes." WALL STREET (Twentieth Century Fox 1987). As Arnold puts it, they "siphon pure profits from the residual claimant and quasi-rents from the...hapless capital provider into [their] own pocket[s] ... [e.g.,] in the form of inflated salaries, perks, and other forms of on-the-job consumption." ARNOLD, PHILOSOPHY AND ECONOMICS, supra note 11, at 141.

210 Dow, supra note 7, at 248.

211 Id. at 247.

${ }^{212} I d$. at 246. "Investors who lack control may worry that workers will use their decision-making powers in an opportunistic fashion." Id. at 188. As Gekko reminds us, this does not seem to deter investors from investment in capitalist firms, where the investors who lack control, see supra notes 133-34 and accompanying text, know that management will act opportunistically. WALL STREET, supra note 209; see also Dow, supra note 7, at 247.

${ }^{213}$ Ho, supra note 152, at 322 (discussing how "many Wall Streeters came to believe that they had in fact mastered risk" by "commoditizing it"). For a clear explanation of how 
Dow invokes moral hazard considerations, stating that workers might leave a failing labor-managed firm, ${ }^{214}$ thus creating reluctance for outside investors or creditors to put up capital. He does not explain how this problem is worse than the risk that capital providers face with capitalist firms that can declare bankruptcy in the face of collapse, leaving unsecured creditors or equity investors with pennies on the dollar-if they are lucky. Dow dismisses the fact that, with a labor-managed firm as with a capital-managed one, insofar as a lender has a security interest in the assets bought by the investments with the loans, whether a mortgage on real estate or a claim to capital goods as collateral, ${ }^{215}$ the lender is in precisely the same position in both cases, and the

Wall Street came to this delusion, see generally BETHANY MCLEAN \& JOE NOCERA, ALL THE Devils ARE HeRE: THE HidDEN History OF THE FINANCIAL CRISIS (2010).

Dow's book was published in 2003, after the bursting of the dot-com bubble might have undermined the idea, suggested to me by Joel Rogers, that labor-managed firms are perceived as too risky by bankers and other lenders whose "conservatism is hard to overestimate." Email from Joel Rogers, Professor of Law, Univ. of Wis. Law Sch., to Justin Schwartz, Assistant Professor of Law, The John Marshall Law Sch. (May 1, 2011, 10:23 AM CST) (on file with author). As I write, we still live under the shadow of the crisis caused by irrationally risky investments. Richard Posner, in his elegant account of the depression (he is not one to mince words) of 2008 , notes with respect to the housing bubble that, with the reduction or elimination of bank regulation, which he argues were the proximate causes of the current crisis, "banks became willing to make 'subprime' mortgage loans-a euphemism for mortgage loans to people at high risk of defaulting. (Some of these loans are what are called NINJA loans-no income, no job, no assets ... [and no] credit check ....)" POSNER, supra note 47, at 23.

Moreover, Posner observes, "the attractiveness of risky ... investing is enhanced by the asymmetrical response of most investors to ... an investment strategy. A strategy that produces good results attracts new investments .... [But a fund that] does poorly ... will lose investors ... at a slower rate than it gains them when it does well." Id. at 26. To say that the banks acted recklessly is a ludicrous understatement. See id. at 41-74 (describing how the great financial institutions of America-Bear Stearns, American International Group, Fannie Mae, Freddie Mac, and other beneficiaries of the government's TARP bailout-went down like ninepins when the bubble burst); see also SORKIN, supra note 47, at 355-63 (describing the bailout, as well as Lehman Brothers' demise as a nonbeneficiary of TARP); discussion supra note 47 (same).

Nor is scandalously risky, and sometimes criminal, behavior limited to mortgage lending. Consider Enron, the poster child firm for most of the 1990s, which was in reality a mirror maze that ran for a decade, essentially, on the irrational, Peter Pan-like conviction of the banks and the investors that a firm that generated no cash, borrowed little money, and issued little stock, could somehow fly. See MCLEAN \& ELKIND, supra note 152, at 323 (quoting one analyst as saying to Fortune magazine in 2000, "How exactly does Enron make its money? ... If you figure it out, let me know."'). Lest these instances be thought anomalous, consider the long history of financial crises. See generally CHARLES P. Kindleberger, MANias, PANICS, AND CRAshes: A History of FinANCIAL Crises (rev. ed. 1989).

${ }^{214}$ Dow, supra note 7 , at 186 . Dow does not, here, phrase this in terms of an initial financing problem, as I have here reframed it.

215 Id. at $246-47$. 
equity investor is no worse or better off facing failure or default with either sort of enterprise.

\section{The Reality of Self Financing}

It is striking, however, that outside financing for labor-managed firms is almost as rare as such firms themselves. ${ }^{216}$ Mondragón, unusually, has established its own cooperative bank, the Caja Laboral Popular, but this is virtually unique, and can be only marginally characterized as "outside" financing. ${ }^{217}$ The kibbutzim were partly financed by land grants from the Israeli government or proto-state Zionist organizations, ${ }^{218}$ and received government assistance when they faced economic crisis in the 1980 s. $^{219}$ This was genuine outside financing, but not precisely by investors. The early plywood co-ops are a rare instance of cooperators raising capital by straightforward classic business lending. They "had no difficulties in arranging short-term loans to cover raw material, inventories, or operation expenses," collateralized by co-op assets. ${ }^{220}$

${ }^{216} I d$. at 190 (noting that "'traditional workers' cooperatives have been financed almost entirely by the personal savings of their members and retained earnings").

217 See MORRISON, supra note 74, at 86-102; THOMAS \& LOGAN, supra note 16, at 7595; WHYTE \& WHYTE, supra note 16 , at $68-87$. With a stretch, the Caja might be regarded as "outside" financing, although it is a member cooperative of Mondragón, at least in that it is not part of the credit-seeking cooperative asking for the loan. Moreover, the start-up funds for Mondragón's founding cooperative were provided externally. See infra Part IV.B.

218 See GAVRON, supra note 16, at 19-20 (describing how some pre-State kibbutzim borrowed capital from the Zionist Settlement Office); SPIRO, supra note 16, at 71 (discussing how one kibbutz received its land from the Jewish National Fund).

${ }^{219}$ See supra note 47 and accompanying text (discussing the Israeli government bailout of the kibbutzim).

${ }^{220}$ Dow, supra note 7 , at 52 . Subsequent plywood co-ops were often organized by "members or organizers of already existing co[-]ops" and were financed in part by "workers seeking self-employment, local businesspeople interested in the economic vitality of the region, and individual promoters" who "hoped to achieve quick capital gains." Id. Two of the latter were convicted of securities and mail fraud, "[bringing] the formation of new cooperatives to an abrupt halt." Id. The frequency of fraud, however, does not stop ordinary lenders and investors from putting their money into capital-managed firms that may be shady, like Enron. See, e.g., Ho, supra note 152, at 78; MCLEAN \& ELKIND, supra note 152, at 85 (noting that Enron was touted as a top firm throughout the 1990s); POSNER, supra note 47 , at 83-85 (noting investor tolerance, even preference, for risky investment).

The difference with the plywood cooperatives may have been due in part to the familiarity effect: a certain level of risk of fraud by crooked capitalists and managers is just par for the course with the common and well-known capital-managed firm, whereas an instance of criminal dishonesty involving a rare form of organization such as a labormanaged firm might be enough to scare off even risk-tolerant investors who fear, irrationally, that the unfamiliar form itself may involve unacceptably high dangers of fraud. See supra note 15; infra notes $226-27$.

Further, there is well-documented social psychological evidence of the phenomenon of giving undue weight to facts that are salient or "available" if not necessarily representative. See Amos Tversky \& Daniel Kahneman, Availability: A Heuristic for Judging Frequency 
But these are not standard cases. Labor-managed firms tend to rely on selffinancing, but Dow does not identify a significant difference between labormanaged and capital-managed enterprises in their behavior or the risks they pose to the creditors or lenders that would explain this puzzling phenomenon. I suggest two possibilities for further investigation.

One potential difference, in Branko Horvat's vivid expression, is that cooperatives find it hard to obtain bank and trade credits because capitalist enterprises and lenders "spontaneously reject[] the alien tissue."221 Dow puts bones under this flesh by suggesting that with respect to debt financing, "bankers have found it awkward to deal with the democratic governance system used by the coops, and ... the coops have likewise been reluctant to accept contractual restrictions imposed by bankers." ${ }^{222}$ The same point could apply equally to equity investors. Lenders and outside investors may "prefer to deal with undemocratic firms having a single peak owner because it is easier to influence the policies of such firms." 223 But this simply recreates the sort of problems Hansmann and Arnold failed to solve with asymmetries between labor-managed firms and corporations, which also lack a "single peak owner." 224 Why, on this reasoning, should creditors and investors be willing to give money to corporations but not to cooperatives?

One explanation of why bankers and investors might prefer to deal with less productive but more familiar capitalist enterprises that avoid these problems, but does not appear to have been explored in the literature, is suggested by Alchian's point that nothing succeeds like success. 225 The very rarity of labormanaged firms might create doubts by lenders and creditors simply because they are unfamiliar: it is less that their behavior is predictably more problematic to capital suppliers than that such enterprises may be unattractive to them because they are less familiar. Social psychological research indicates that the "mere exposure effect," the tendency to prefer the familiar, ${ }^{226}$ has a measurable

and Probability, 5 COGNITIVE PsYCHOL. 207, 207 (1973). A few such instances in a very rare organizational form are likely to be a far higher proportion, and so more salient, than even a much larger number of instances in a common form, irrationally tainting investor perceptions of labor management in a way that a comparatively high frequency of fraud does not thus taint their view of capital management. I know of no evidence that labor management is unusually corrupt. The fraudsters in the plywood cases were outside investors, not employees.

221 Horvat, supra note 16 , at 456.

222 Dow, supra note 7, at 190 (noting that "[n]on-voting equity is almost never used by [labor-managed firms]").

${ }^{223}$ Id. at 186-87. In a classic capitalist firm, this might be a limited partner, who receives profits but takes no part in management of the enterprise.

${ }^{224}$ See supra notes $127-53,181-86$ and accompanying text.

225 "[P]atterns of behavior and organization are predictable... if they are tried." Alchian, supra note 9, at 220.

226 Also called the "familiarity principle." See, e.g., Bornstein, supra note 15, at 265 (reviewing studies that document the "mere exposure effect"); Chip Heath \& Amos Tversky, Preference and Belief: Ambiguity and Competence in Choice Under Uncertainty, 4 J. RISK 
effect on investment decisions. ${ }^{227}$ Dow hints at something like this when he states that "it can be costly to create a reputation for cooperative behavior, but a reputation of this sort could be a vital prerequisite for attracting inputs without granting control rights." 228 To what extent this creates possibly irrational bank or investor aversion to labor-managed firms is unknown, but if Alchian is right, those who overcome the familiarity bias might be expected to have more success in the capital market.

The other, very different sort of explanation that Dow suggests is that labormanaged firms might resist outside financing because "workers are vulnerable to opportunistic abuse by investors [or lenders]" 229 who might insist on control rights as a condition for extending credit, perhaps because of the mere exposure effect, and then use that control to exploit the workers or deprive them of the advantages that make a democratic labor-managed firm attractive to begin with. 230 This theory has empirical support. Dow cites a study arguing that to avoid the perceived risk of certain sorts of employee opportunism, "lenders take over the management of the production process." 231

Whatever the cause of the general tendency of labor-managed firms to be self-financing, the ability of workers to raise large sums on their own-enough, e.g., to take over United Airlines-raises serious questions about Dow's theory that labor-managed firms are rarely started because they face higher costs of obtaining capital than do capital-managed firms. ${ }^{232}$ Dow admits that the existence of ESOPs suggests that even where workers bear the brunt of initial financing, "workers may be better able to supply capital than has sometimes

\& UnCERTAINTY 55 (1991); Angela Y. Lee, The Mere Exposure Effect: An Uncertainty Reduction Explanation Revisited, 27 PERSONALITY \& SOC. PSYCHOL. BULL. 1255, 1255 (2001). This effect helps account for the importance of name recognition in advertising, see Jochim Hansen \& Michaela Wänke, Liking What's Familiar: The Importance of Unconscious Familiarity in the Mere-Exposure Effect, 27 SOC. COGNITION 161, 161 (2009) (demonstrating that mere exposure to brand names increases liking for the names independently of conscious recognition of the exposure); political campaigns, see Paul E. Schaffner et al., Candidate Name Exposure and Voting: Two Field Studies, 2 BASIC \& APPLIED SOC. PSYCHOL. 195, 195 (1981); and even academic evaluation, see Alexander Serenko \& Nick Bontis, What's Familiar Is Excellent: The Impact of Exposure Effect on Perceived Journal Quality, 5 J. INFORMETRICS 219, 219 (2011). This is not necessarily irrational insofar as what is familiar is more predictable. It may be irrational insofar as what is predictably familiar is opportunistic and excessively risky behavior.

${ }^{227}$ See Gur Huberman, Familiarity Breeds Investment, 14 REV. FIN. STUD. 659, 659 (2001).

${ }^{228}$ Dow, supra note 7, at 189.

${ }^{229} \mathrm{Id}$. at 188 .

${ }^{230} I d$. at 189.

${ }^{231}$ Id. at 186 (citing Mukesh Eswaran \& Ashok Kotwal, Why Are Capitalists the Bosses?, 99 ECON. J. 162, 162 (1989)).

${ }^{232}$ It may, however, help explain in part the observed distribution of employee ownership. See HANSMANN, ENTERPRISE, supra note 2, at 76-77. 
been assumed."233 He notes that employees in some capital-managed firms, such as sports teams and film companies, have enough wealth to buy them, or even in some cases to create labor-managed firms on their own, ${ }^{234}$ but generally do not. On a less well-remunerated level of employment, Dow further points out that workers in existing co-ops have paid steep entry fees, e.g., to join the plywood cooperatives or Mondragón. 235 Union pension funds "can also have assets exceeding the net worth of the firms that employ the union's members."236 As Hansmann says, dismissing Dow's general sort of capital formation account: "The proliferation of ESOPs in the manufacturing sector indicates that a firm's employees can themselves provide substantial equity capital without crippling costs." 237

Dow's capital constraints explanation of the rarity of startups of labormanaged firms, then, is not persuasive. There is no evident reason that they are inherently less creditworthy than capital-managed firms. There are differences in the way existing labor-managed and capitalist firms are financed that call for further investigation. I have suggested two avenues of research into why labormanaged firms tend to be self-financed-their unfamiliarity to lenders and investors and employee reluctance to surrender control to outside capital.

${ }^{233}$ Dow, supra note 7, at 191. Dow notes that in ESOPs workers have rarely if ever exercised effective control over capital financing and investment, even where they put up the money. Id.; see also HANSMANN, ENTERPRISE, supra note 2, at 75-76 ("The proliferation of ESOPs in the manufacturing sector indicates that a firm's employees can often provide substantial equity capital without crippling costs.").

234 Dow, supra note 7, at 192. United Artists was formed in 1919 by star actors and directors like Charlie Chaplin and D.W. Griffith, but faltered after initial success and finally went public in 1957. See TINo BaLIO, UNITED ARTISTS: THE COMPANY BUILT BY THE STARS 13,239 (1976). Unlike the producer co-ops I have been discussing and more like the large law firms Hansmann treats as employee-owned enterprises, however, United Artists had a traditionally hierarchical management structure and a grossly unequal pay scale, id., and probably for similar reasons.

235 Dow, supra note 7, at 192-93. Dow states that "the workers who paid these prices were not in any sense a representative sample of the labor force as a whole." Id. at 193. See infra note 272 on the high costs of buying into the plywood cooperatives or Mondragón. Moreover, one wonders why workers with exceptional reserves of wealth would seek essentially unskilled, traditional manual labor in a plywood factory, although obviously a fair number of them did so in the plywood industry.

${ }^{236}$ Dow, supra note 7 , at 192 . Union pension assets become less significant as union membership falls: "The percentage of private sector workers in unions [union density] fell to 6.9 percent [in 2010], down from 7.2 percent, the lowest rate for private sector workers in more than a century...." Stephen Greenhouse, Union Membership in U.S. Fell to a 70-Year Low Last Year, N.Y. TIMES, Jan. 21, 2011, http://www.nytimes.com/2011/01/22/business/ 22 union.html. However this does not explain why unions did not use their economic power to buy out their members' employers in the mid-twentieth century, when they represented up to a third of the nation's private sector workers. BOWLES ET AL., supra note 130, at 166 (citing the Bureau of Labor Statistics).

${ }^{237}$ HANSMANN, ENTERPRISE, supra note 2, at 75-76. 
However, Hansmann's conclusion that capital constraints are not the key barrier, nor perhaps even a really significant one, appears to be correct.

\section{Where Mill Went Wrong: A Public Goods/Collective ACTION ACCOUNT}

\section{A. Public Goods and Collective Action-The Theoretical Framework}

So where did Mill go wrong? The reasoning behind Mill's prediction that the labor-managed and -owned firm should come to predominate in the market over traditional capitalist rivals is not merely plausible but also well supported by empirical evidence. Such firms have a significant productivity advantage, ${ }^{238}$ which rebuts the purported explanation that they have not proliferated because of their alleged inefficiency. And they appear to have a profitability and survival rate no worse, and possibly better than, traditional capitalist competitors, ${ }^{239}$ whatever costs their operation, or their creation, may pose. Problems with raising capital do not explain why they are so rare, although the reasons that they are not funded by outside investors calls for investigation. Furthermore, they embody democratic features that workers who have experienced say that they value. ${ }^{240}$ Given the efficiency advantages and worker preferences, workers should have formed many successful labor-managed enterprises owned by themselves and, other things being equal, triumphed in the market, at least over the corporation if not over the classic capitalist firm as well. And yet they have not. Why not?

The explanation I propose is both novel and strikingly obvious, but has received virtually no attention by scholars. It turns on the sort of collective action or public goods problem identified by Mancur Olson as an obstacle to the formation of groups that have a common interest, economic or other. ${ }^{241}$ In addition, I hypothesize that the mere exposure effect may magnify this obstacle. The explanation can be stated in two sentences:

(1) A labor-managed firm is a public good that faces the obstacles set forth by Olson, according to which collective action to provide public goods tends to generate incentives to free ride and produce suboptimal outcomes. ${ }^{242}$

${ }^{238}$ See supra notes $42-46$ and accompanying text.

${ }^{239}$ See supra notes 47-49 and accompanying text.

${ }^{240}$ See supra note 51 and accompanying text.

241 See OLSON, supra note 14, at 14-15.

242 Why this has not been proposed and investigated at the length and with the intensity of explanations like those we have considered is odd given the extensive attention to public goods problems in the social scientific, legal, and philosophical literature. To give an indication of scholarly neglect of this sort of explanation, consider the three authors whose works I have taken as my targets and who cover, among them, practically all the important literature on the topic in English. The terms "collective action," "free rider," "public good(s)" or "prisoner's dilemma," of which the public goods problem is a generalization, see 
(2) Being unfamiliar, it is therefore less attractive to workers and perhaps investors and lenders.

Ironically, Mill himself, in typically crystalline prose, recognized the problem in a different context, viz., why government action was required to limit the working day. Such a reform "will not be adopted unless the body of operatives bind themselves to one another to abide by it."243 But, "however beneficial the observance of the regulation might be to the class collectively, the immediate interest of every individual would lie in violating it." 244 Olson could not have said it better. But Mill did not see that this problem also applied to "operatives" creating their own "associations." 245

The theoretical framework of the collective action or public goods problem is familiar and may be stated briefly. A public good is defined as one that satisfies the common interest of the members of a group and from which no member can be excluded whether or not he participates in creating it. ${ }^{246}$ Olson showed that it is (economically) rational, ${ }^{247}$ other things being equal, for each

infra notes 246-55 and accompanying text, do not appear in the index of Amold's The Philosophy and Economics of Market Socialism. See ARNOLD, PHILOSOPHY AND ECONOMICS, supra note 11, at 294-302. Arnold's "opportunism" is a version of a free rider problem, but very different from the one considered here. Olson's name and work is not cited in his bibliography. See id. at 283-91. Hansmann considers public goods in the very narrow context of a role for nonprofit firms, see HANSMANN, ENTERPRISE, supra note 2, at 230-31; the terms "collective action," "free rider," "prisoner's dilemma," and Olson's name are not in his index, see id. at 365-72. He has no separate bibliography. Dow mentions, in a single paragraph, "major collective-action problems [that] arise in the course of an employee buyout," but does not raise the issue in a wider context. Dow, supra note 7, at 220 (emphasis added). He also uses the term in considering Hansmann's heterogeneity theory, but, as we have seen, this is a completely different explanation of a different phenomenon. "Collective action," makes no other appearance in his extremely comprehensive survey of the rarity of worker's control, and Olson's work also fails to appear in his bibliography. See id. at 291311. The closest approach to this sort of explanation that I have discovered is Schweickart's very short, unelaborated two-sentence statement, not citing Olson or any literature on the subject, not using the terms "collective action," "public good," "free rider," or "prisoner's dilemma," and without stating either the premises or, precisely, the conclusion of the collective action problem. See SCHWEICKART, AGAINST, supra note 5, at 239; infra notes 271-279 and accompanying text.

243 MiLL, supra note 4, at 963.

244 Id. at 964.

$245 \mathrm{Id}$. at 963 . The problem was recognized, much more recently, by Analytical Marxists as an obstacle to social revolution. See, e.g., Allen Buchanan, Revolutionary Motivation and Rationality, 9 PHIL. \& PUB. AfFaIRs 59, 62-66 (1979).

246 OLSON, supra note 14 , at 14-15.

${ }^{247}$ See supra note 202 (discussing the elements of economic rationality). Olson further underlines that "[e]conomic incentives are not ... the only incentives; people are sometimes also motivated by a desire to win prestige, respect, friendship, and other social and psychological objectives." OLSON, supra note 14 , at 60 . There may be "social incentive[s]" to contribute even where economic ones are lacking. Id. These, Olson considers only when they operate through "social pressure," id. at 60 , and insists that they be analyzed "in much the same way as monetary incentives," id. at 61 . He mentions "moral incentives" in a 
not to contribute to the creation or maintenance of the good, or at least not to the optimal level. ${ }^{248}$ Rather, the incentive to provide more of the collective good ceases once the amount of the good that would be obtained by the individual with the largest fractional contribution is reached. ${ }^{249}$ Each member has an incentive to take advantage of the actions of others in providing the public good by enjoying it without contributing, or contributing as much-to be, in short, a "free rider." The likelihood and seriousness of such opportunistic behavior, Olson thought, varied inversely with the size of the group, ${ }^{250}$ declining with smaller groups. But "[e]ven in the smallest groups ... the collective good will not ordinarily be provided on an optimal scale.... [T] he members of the group will not provide as much of the good as it would be in their common interest to provide." 251 This is because any member will capture only part of his expenditure towards provision of the good, and every member will benefit by the efforts of others to provide it however much or little he contributes. ${ }^{252}$ With larger groups, the contribution of any individual member matters less, and the marginal share of benefit per contribution to any members, and thus the incentive to contribute, also declines. This is an a priori, top-down, rational choice explanation. It should be embedded in a historical context with detailed psychological and economic analysis. I have supplemented this account with

footnote, stating that they "could . . be analyzed within the framework of the theory." $I d$. at 62 n.17. He claims that insofar as there are "selective incentives" that create social pressure, they may overcome the disincentives that create the collective action problem. Id.

Olson's characterization of action motivated by morality and honor or respect as deriving from a desire for "personal gain," to be analyzed similarly to "monetary incentives," and treated as individual self-interested extrinsic benefits, reflects the typically jaundiced perspective of an economist. It is bizarre to reduce the inclination to do the right thing to something like the satisfaction one gets from feeling that one has done the right thing, much less to treat it as if the benefit to oneself were something like the acquisition of monetary gain.

It also is flatly false that such nonmonetary motivations-for example, moral, religious, or ideological ones - operate only through social pressure. Max Weber, for one, knew better, characterizing a fundamental type of motivation as wertrational, "value rational," being motivated by the intrinsic worth of the aim to the individual himself. MAX WEBER, The Nature of Social Action, in MAX Weber: Selections IN TRANSLATION 7, 28 (W.G. Runciman ed., E. Matthews trans., Cambridge Univ. Press 1978) (1922); see infra notes 263-264 and accompanying text; see also infra Part IV.C. To take an example from Weber's territory, see generally MAX WebER, THE PROTESTANT ETHIC AND THE SPIRIT OF CAPITALISM (Talcott Parsons trans., 1930), what social pressures drove Martin Luther to post his Ninety-Five Theses on the door of the Castle Church in Wittenburg in 1517? "Hier stehe ich, ich kann nicht anders"- "Here I stand; I cannot do otherwise"- he is reputed to have said. ROLAND BAINTON, HERE I STAND 187 (1950). (Ecclesiastical reform is a public good.) The social pressures and physical incentives were all the other way. Had he lost, Luther might have faced the Inquisition.

248 OLSON, supra note 14 , at 28.

249 Id.

250 Id. at 35.

251 Id. at 34.

252 Id. at 35. 
some social psychological research. A larger and more integrated treatment must await future work.

The strategic structure of the logic of collective action is that of the $n$ person prisoner's dilemma. ${ }^{253}$ The classic two-person prisoner's dilemma ${ }^{254}$ shows that a one-off encounter with no opportunity for the parties to coordinate, the strategic interaction between rational players who seek their best outcome will result in a suboptimal outcome for each and a worse outcome overall than if they did not seek their individual best outcome. In the standard illustration, 255 the police have two individuals, call them "You" and "Me," in custody for a crime we committed jointly. Each of us would prefer to do less time, and neither cares how much time the other does. The amount of time translates directly into ordinal preference rankings for outcome, with one being the highest-ranked preference and four the lowest for each of us. If we both stay silent, the prosecution can convict us of a crime punishable by two years. If I confess, implicating You, You can be sentenced to four years, while I receive only one year. If we both confess, however, we will each be eligible for three years. It might seem that the rational thing to do is for both of us to remain silent, in which case we each receive our second-best outcome-two years. But I can do better, attaining my best outcome, one year, if I talk and You don't. The situation is symmetrical: what holds for one holds for the other. It is (economically) rational for Me to confess ("defect," in the language of game theory), but it is likewise rational for You to do the same. If we both confess, however, we each receive our third-best outcome-three years- a suboptimal result. The dilemma can be represented by the following famous matrix:

Figure 1: The Prisoner's Dilemma

\begin{tabular}{llll} 
& \multicolumn{2}{c}{ You } \\
& & You stay silent & You confess \\
Me I stay silent & 2,2 & 4,1 \\
I confess & 1,4 & 3,3
\end{tabular}

253 See HARDIN, supra note 14, at 2; Russell Hardin, Collective Action as an Agreeable n-Prisoners' Dilemma, 16 BEHAVIORAL SCI. 472, 472 (1971). See also the "tragedy of the commons," a famous, informal $n$-person version developed by Garrett Hardin (no relation). Garrett Hardin, The Tragedy of the Commons, 162 SCIENCE 1243, 1244 (1968) (arguing that individual rationality will degrade common resources, such as a shared field in which farmers graze their cattle).

254 See generally ANatol Rapoport \& AlBert M. Chammah, Prisoner's Dilemma: A STUDY IN CONFLICT AND COOPERATION (1965) (the classic study). The paradox seems to have been first formally expressed in a study by RAND Corporation analysts Merrill $\mathbf{M}$. Flood and Melvin Dresher in 1950, and named the "prisoner's dilemma" by RAND consultant Albert W. Tucker. See William Poundstone, Prisoner's DilemMa 8, 100-05 (1992).

${ }^{255}$ Formulated by RAND's Albert Tucker. See PoundSTONE, supra note 254, at 11618. 
The strict logic of the dilemma applies to the two-person case with the stated assumptions.

$N$-person games are far more difficult to analyze. Robert Axelrod has shown that if the parties engage in repeated interactions, then reciprocity and cooperation are stable and rational outcomes. 256 One explanation for Olson's result that suboptimality increased with group size is that large, increasingly anonymous groups are closer to the one-off, single-interaction situation of the classic prisoner's dilemma. The prisoner's dilemma is generally thought to presuppose egoism, ${ }^{257}$ but even Olson observed at one point that the prisoner's dilemma-like logic of his argument required no such assumptions when the group was large enough that the contributions of even the most altruistic, collective-minded member "would not be perceptible." 258

Moreover, and this is crucial, the problem can be overcome in at least two ways. One is to change the incentive structure, for example, by making cooperation compulsory or desirable, as governments may by enacting law. ${ }^{259}$ Informal social pressure often takes the place of law in giving people an incentive to cooperate ${ }^{260}$ Another, as Olson expresses it in a characteristic economist's way, is for at least one member of a group to "find that his personal gain from having the collective good exceeds the total cost of providing [it]."261 Olson views "personal gain" broadly to include, e.g., moral or other nonmaterial benefits sufficient to motivate individual action. ${ }^{262}$ The idea that moral and other nonmaterial benefits are understood as "personal gain" analyzed

256 See, e.g., ROBERT AXELROD, THE EVOLUTION OF COOPERATION 27-54 (1984) (showing by computer modeling that it is rational to cooperate in repeated interactions unless the other person defects - the strategy of Tit for Tat, that is, to do what the other player did on the last round, a strategy devised by Anatol Rapoport). For informal discussion, see POUNDSTONE, supra note 254, at 236-55.

${ }^{257}$ In fact it does not depend on egoism. This can be shown as follows: nonegoistic motivations such as the desire that I receive my just deserts can be rank-ordered in the matrix in the same way as selfish ones. Suppose my first choice is that I suffer fully for my crime, that is, I prefer to get more time rather than less, and my choices are rank-ordered accordingly. As before, the prosecution will give each of us less time if we talk. If your motivations mirror mine, the same suboptimal result occurs, although here the incentive for each is to not talk, because talking reduces the time we do. Here neither of us talk, and we each do less time, contrary to our wishes. In this case, the adventitious match between the number of years and the ordinal ranking in my previous presentation of the classic prisoner's dilemma comes apart. Two years, what we get if neither talks, is our third-ranked result. But this does not matter to the logic of the argument.

258 OLSON, supra note 14 , at 64 . The need to overcome collective action problems and provide public goods is a standard explanation of and justification for the existence of government and its coercive power.

259 Id. at 13.

260 See id. at $60-61$; see also RoBert Ellickson, Order Without LAW: How NEIGHBORS SETTLE DiSPUTES 123-30 (1991).

261 OLSON, supra note 14 , at 34 (small group context).

262 See id. at 61 n. 17. 
analogously to monetary gain is a perversely reductionist perspective. ${ }^{263}$ It also creates a public goods issue for morality itself. ${ }^{264}$ This assumption is, in addition, unnecessarily strong. As we shall see, we can maintain the public goods explanation while granting that people are motivated by a richer and more complex set of motives. ${ }^{265}$ With regard to overcoming a collective action problem, the real point is that at least one person must have a motivation, independent of the collective good, to achieve it. "Hier stehe ich, ich kann nicht anders."

\section{B. The Theory Applied to the Formation of the Labor-Managed Firm}

The literature on collective action and prisoner's dilemmas is almost inconceivably vast and metastasizing rapidly. ${ }^{266}$ However, for my purposes I need not attempt to address the complexities. As stated, a labor-managed firm is a public good in the precise sense that it offers benefits for its members from which no member can be excluded - with labor management, the advantages of participation, egalitarianism, job security, and other benefits, as well as nonpublic goods like profits that do not have to be shared with capitalists or

${ }^{263}$ See, e.g., ElizaBeTH ANDERSON, VALUE IN ETHICS AND ECONOMICS 31, 86-90 (1993) (critiquing, inter alia, egoistic assumptions underlying economic rationality as a theory of behavior); ElliotT SOBER \& DAVID SLOAN WILSON, UNTO OTHERS: THE EVOLUTION AND PSYCHOLOGY OF UNSELFISH BEHAVIOR 296-327 (1998). See generally Martha C. Nussbaum, Flawed Foundations: The Philosophical Critique of (a Particular Type of) Economics, 64 U. CHI. L. REV. 1197 (1997).

264 The problem is ancient. See Plato, RePuBlic 359a-360d, at 31-32 (G.M.A. Grube trans., Hackett Publ'g Co. 1974) (discussing the mythical ring of Gyges and suggesting that, if a "just" person possessed such a ring that made him invisible so he would never be caught or punished for whatever malfeasance he committed, he would cease to act justly). On rational choice-theoretic assumptions, as a number of modern writers have observed, to say that "doing the right thing" is a matter of "personal gain" makes morality a public good that generates a collective action problem. Advocates of that approach have struggled mightily but without success to derive morality from economically rational self-interest. See generally Russell HaRdin, MoRality Within the LIMITS OF REASON (1988); DaVID GaUTHIER, MORALS BY AGREEMENT (1986). The collective goods problem can be avoided if morality is not viewed as a product of the actions of egoistic agents, and our circumstances are Axelrodian rather than Olsonian. See supra note 226.

265 See supra note 257 (for a short proof that prisoner's dilemmas do not require egoism but are consistent with nonegoistic motivation); see also infra Part IV.C and accompanying text (for explanation of how the collective action problem can be generated without the unrealistic egoistic assumptions). Olson admits this with regard to infinitesimal contributions to the activities of large groups. See supra note 258 and accompanying text.

266 According to Christian Donninger, over a thousand articles on the prisoner's dilemma alone were published in the 1960s and 1970s. Christian Donninger, Is It Always Efficient to Be Nice?, in PARADOXICAL EFFECTS OF SOCIAL BEHAVIOR: ESSAYS IN HONOR OF ANATOL RAPOPORT 123-24 (Andreas Diekmann \& Peter Miller eds., 1986), cited in Steven Kuhn, Prisoner's Dilemma, STAN. ENCYCLOPEDIA OF PHIL., http://plato.stanford.edu/entries/prisoner-dilemma/ (last revised Oct. 22, 2007). The encyclopedia entry itself is forty-nine pages printed out single-spaced in twelve-point type. 
(perhaps) investors. This raises the specter of a collective action problem. Forming a labor-managed firm involves individuals pooling their resources and coming to a mutually satisfactory agreement about how to set up and manage a business - an agreement in which each must trust the others, and where enough of them actually follow through to provide the public good. Insofar as economic rationality impinges on their motivation, ${ }^{267}$ or their behavior tracks such rationality whatever their motivation, it creates incentives for free riding and opportunistic behavior.

At the limit case, there will be no collective action and the public goodthat is the labor-managed firm-will not be provided at all. As Olson notes, the problem becomes more difficult as more people are involved. It is therefore not surprising that most of the few labor-managed firms are small. In contrast, setting up as a small capitalist on one's own avoids the problem altogether. So workers who are discontented "with the condition of labouring for wages as their ultimate state"268 are far more likely to start their own businesses than to found cooperatives. ${ }^{269}$ According to the Small Business Administration, approximately 552,600 new employer firms began operations in 2009 , and 660,900 firms closed that year, roughly a $10 \%$ annual turnover. 270 The number of labor-managed firms in the United States is barely even inconsequential.

Schweickart, far too briefly, suggests that something like a collective action problem may be involved in accounting for why such enterprises are rarely formed: "[E]ach new cooperative venture (in a capitalist society) requires a new wealthy radical or a new group of affluent radical workers willing to experiment.... [S]uch people doubtless are in short supply...."271 As

${ }^{267}$ For objections to the dubious assumption that people actually are economically rational actors, see supra notes 202, 226, 263.

268 MiLL, supra note 4 , at 760.

${ }^{269}$ G.A. Cohen, considering whether wage workers are free to leave the working class, contends that they are individually free to do so by starting small businesses. See G.A. Cohen, The Structure of Proletarian Unfreedom, 12 PHIL. \& PUB. AfF. 3, 7 (1983). He does not even mention the possibility of collective action to form cooperatives.

${ }^{270}$ Frequently Asked Questions, U.S. SMALL BUS. ADMIN., http://www.sba.gov/sites/ default/files/sbfaq.pdf (last updated Jan. 2011).

${ }^{271}$ SCHWEICKART, AGAINST, supra note 5, at 239. These two sentences are the only place in literature going back 150 years in which I have found the collective action problem, here not so named or expressly spelled out, is even obliquely suggested to explain why so few cooperatives are started. Schweickart ties his analysis to the "Ward effect" of the "Illyrian firm," which modeling on neoclassical assumptions shows is self-limiting in size because "enterprise growth would bring in new workers with whom the increased proceeds would have to be shared. Cooperatives, even when prosperous, do not spontaneously grow." Id.; see also WARD, supra note 8, at 196. Schweickart does not here explicitly cite Ward for this proposition, see SCHWEICKART, AGAINST, supra note 5, at 239, but he discusses the Ward effect in the different context of considering perverse incentives faced, under neoclassical assumptions, by already-existing cooperatives, id. at $91 \& \mathrm{n} .28$. See also supra note 8. However, Schweickart does not require the Ward effect to make his point about the need for cooperative entrepreneurs to overcome public goods problems to get cooperatives up and running. Olson's collective action theory is a sufficient basis for this prerequisite. 
expressed, this is not quite right. Start-up capital is necessary, but we have seen, discussing Dow's capital shortage explanation, that "affluence" is too strong. Buy-in costs of existing cooperatives may be high. ${ }^{272}$ However, the case of ESOPs shows that workers throughout the U.S. economy are able to raise the capital to take very substantial or total ownership shares in large corporations; the workers who owned United Airlines during its ESOP period were not especially affluent. ${ }^{273}$ In addition, although again it is quite rare, there is no evident rational economic obstacle to labor-managed firms obtaining start-up funds from bank loans or stock or bond issues. ${ }^{274}$ The founders of a cooperative need not be radical; the moving spirit of the ESOP, Louis Kelso, was anything but; its main legislative sponsor, Senator Russell Long, was a populist, but in no sense a militant. ${ }^{275}$ Given the cold facts about the economic efficiency advantages of labor management, a businessperson or investor might simply look at financing such an enterprise as good business and even act as a (selfinterested) entrepreneur in helping to start one. ${ }^{276}$ Or an entrepreneur might have nonmonetary motivations. Don José María Arizmendiarrieta (commonly called Arizmendi), the priest who founded Mondragón, initially as a school in the early 1940s, was an idiosyncratic radical, ${ }^{277}$ although far from wealthy. In

${ }^{272}$ The first plywood co-op was established in 1921 by 125 workers who each contributed $\$ 1000$, GUNN, supra note 53 , at 100 , a very substantial sum in that era, equivalent to over $\$ 11,600$ real U.S. dollars in 2012, Inflation Calculator, DOLLAR TIMES, $\mathrm{http} / / / \mathrm{www}$. dollartimes.com/calculators/inflation.htm (last visited Mar. 9, 2012). They then secured a bank loan. GUNN, supra note 53 , at 100 . In the mid-1980s, membership shares in the existing plywood cooperatives sometimes sold for $\$ 100,000$. Id. at 112 . According to Gunn, shares of that value required roughly a $\$ 20,000$ down payment, and payments on the balance of about $\$ 500$ a month at $7 \%-10 \%$ interest in 1979-1982. Id. Shares in less successful cooperatives sold in the range of $\$ 10,000-\$ 25,000$. Id. Becoming a member of a Mondragón cooperative requires payments that vary, but the limits of which are set by the cooperative's bank, the Caja. WHYTE \& WHYTE, supra note 16, at 70. Initial payments of new members rose from $\$ 2000$ in 1975 to about $\$ 5000$ in 1981 , with a repayment period at the time of two years. Id. at 74. This was a significant contribution in Spain at the time. In 2002 , average disposable income per worker in Spain was $\$ 18,723$ (real 2005 U.S. dollars). Spain Average Salaries \& Expenditures, INT'L AVERAGE SALARY INCOME DATABASE, http://www.worldsalaries.org/spain.shtml (last visited Mar. 9, 2012). In 1975, individual members provided $20 \%$ of the startup costs of a new cooperative, the Caja provided $60 \%$, and $20 \%$ was provided by government loans. WHYTE \& WHYTE, supra note 16 , at 74 .

${ }^{273}$ See supra notes 232-37 (discussing why self-financing need not be a serious limitation on forming a labor-managed firm or converting a capital managed firm to a labormanaged one).

274 See supra Part III.C.1.

275 See supra note 58 (sketching the ideological and legislative history of the ESOP).

276 It may be that something like this may have played a role in the establishment of the plywood cooperatives. See infra note 290.

277 Arizmendi supported the Spanish Republic against Franco during the Spanish Civil War, working as a journalist. WHYTE \& WHYTE, supra note 16, at 27-28. In his preaching he stressed the need for cooperation, solidarity, and the dignity of labor. Id. at 29 . The people of Mondragón thought of him as a socialist, id., but while he was familiar with and sympathetic to Marxism, he was not a Marxist. Id. at 231. He called his ideology "cooperativism," and 
addition to self-funding by the cooperators, ${ }^{278}$ he and his collaborators had to obtain outside funding in the form of loans and charitable contributions. ${ }^{279}$

The origin of Mondragón and of the few labor-managed enterprises in the United States illustrates the factors Olson invokes as relevant to overcoming the problem and creating the public good in the absence of coercion. An abbreviated historical account shows three of Olson's conditions for effective collective action, and a fourth that he does not precisely specify, which should be distinguished. Mondragón was founded as a small technical school in 1943. ${ }^{280}$ The first productive enterprise in what was to become the Mondragón complex was Ulgor, which made domestic appliances, ${ }^{281}$ and was established in 1956 by Arizmendi and five graduates of the school. ${ }^{282}$ It employed twenty-four workers. ${ }^{283} \mathrm{We}$ should observe: (1) the small size of the initial founding group, one of Olson's key conditions for creating a public good, and (2) the role of Arizmendi, who was motivated by nonselfish moral, political, and religious considerations. ${ }^{284}$ If we insist with Olson that such motivations should be analyzed in terms of economic rationality, Arizmendi might be regarded as exemplifying the case in which his personal gain from having the collective good in mind exceeds the total cost of providing some amount of that good. 285 In this case, the "personal gain" was the realization of his ideals. To put things in a less strained, more psychologically realistic way that involves no such implausible commitments, we may say that Arizmendi's idealistic radicalism put him outside the sphere of economically rational calculation into the territory of Weberian Wertrationalität, value rationality. There was also (3) "social pressure," another Olsonian condition, 286 shown by the circumstances in which the founders of Ulgor raised the initial capital, relying on relatives, others who

viewed it as "equidistant from individualistic capitalism and soulless collectivism." Id. at 237. For an account of his moral and political views, see $i d$. at 225-53.

278 See id. at 33.

$279 \mathrm{Id}$. at 34.

280 Id. at 30; see also THOMAS \& LOGAN, supra note 16 , at 18.

281 THOMAS \& LOGAN, supra note 16 , at 20 . The complicated history of the foundation of Ulgor is instructive. Arizmendi and the founding members envisaged a cooperative enterprise from the start, but the first enterprise in what was to become Mondragon was initially founded as an LLC in 1954 because they found the existing Spanish law on cooperatives unsuited to their purposes. Through the LCC, they purchased a small bankrupt workshop near Vitoria that made paraffin stoves. Id.; MORRISON, supra note 74, at 47. Ulgor was reconstituted as a cooperative with a new factory making more modern products in 1956 in Mondragón proper, after several years of legal work with outside attorneys to create a model through a new enterprise statute inside the existing legislative framework that the founders believed would enable them to embody many of their ideals. THOMAS \& LOGAN, supra note 16 , at 20.

282 WHYTE \& WHYTE, supra note 16 , at 34-35.

283 THOMAS \& LOGAN, supra note 16, at 21 .

${ }^{284}$ See supra note 277.

285 OLSON, supra note 14 , at 24 .

${ }^{286}$ Id. at 63-64 n.18. 
were ideologically sympathetic, ${ }^{287}$ and some who viewed the cooperative as a good investment. 288

To Olson's conditions, we may add Schweickart's insistence on (4) the role of the entrepreneur, here Arizmendi. I set this off as a distinct condition from (2), "greater personal gain" or noneconomic motivation, because an entrepreneur needs vision, talent, and energy as well as motivation. ${ }^{289}$ Schweickart is therefore right to emphasize the need for entrepreneurship in getting a labor-managed firm up and running, but Arizmendi shows that the entrepreneur may be creative or idealistic rather than merely personally wealthy. Similar factors can be seen with the founding of the first plywood cooperative, the Olympia Veneer Company, which faced somewhat similar challenges and circumstances. ${ }^{290}$

To the collective action problem we should add the "mere exposure" or familiarity effect. ${ }^{291}$ This effect refers to the established result that what is familiar tends to be regarded favorably. Labor management in market societies

287 ThOMAS \& LOGAN, supra note 16 , at 20-21. Family connections, friendship, and social connections through the "old and well-established social custom" of gathering after work to drink and talk to friends (the chiquiteo), see WHYTE \& WHYTE, supra note 16, at 34, through which the five founders gathered support for their idea, could be treated as instances of Olson's "social pressure." The small-size factor-ninety-six individual lenders-comes into play again. None of the lenders or initial equity investors (apart from the five founders) had any part in managing enterprise affairs or shared directly in the public good of labor management. Insofar as they shared Arizmendi's ideals, however, these investors might be characterized as similarly idealistically motivated.

${ }^{288}$ Any such self-interested investors might be accurately described as individuals whose expected personal gain from having the collective good exceeds the total cost of providing some amount of that good, OLSON, supra note 14, at 24, insofar as they can be regarded as beneficiaries of the good at all.

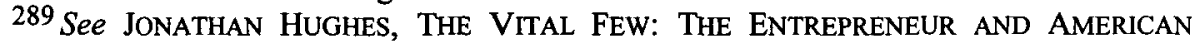
ECONOMIC PROGRESs 22-66, 462-503 (expanded ed. 1986). Arizmendi fits Hughes's model of the "idealistic" entrepreneur. Hughes's examples are William Penn, the Quaker founder of Pennsylvania, and to some extent Mary Switzer, an important architect of the welfare state from the 1930s to the 1950s and an "institutional" innovator.

290 See PlywoOd PioneERs ASS'N, PlywoOd IN RetrosPeCt: OlyMPIA VENEER COMPANY (1969), available at http://www.apawood.org/PPA_StructuralWoodSociety/ pdfs/PPA_07.pdf; see also Dow, supra note 7, at 50-51. The lesser-known entrepreneurs who started the first plywood co-op were Ed Westman and J.J. Lucas. PLYwOOD PIONEERS Ass'N, supra. They saw a business opportunity in a plywood mill "which they themselves could own and operate." Id. It is unclear why, instead of starting a conventional capitalist firm, they chose a cooperative model with labor management and ownership. Sympathy with Marxist or radical ideals is highly unlikely to have had anything to do with it. Olson's condition of the small size of the founding group can also be seen in the 125 members who bought shares in Olympia Veneer-granted that this is a substantially larger group than five workers and a priest. Dow, supra note 7, at 50 . It was, however, comparable in size to the initial group of ninety-one that funded Ulgor, the first Mondragón co-op. Subsequent plywood cooperatives involved founding groups of 250-300 workers. Id. at 51 .

291 See supra notes 226-27 and accompanying text (psychological studies of the effect in various contexts). 
is, to say the least, unfamiliar because it is so rare-the mere exposure effect predicts that it would be rare in part because it is unfamiliar. In contrast, capital management is highly familiar, indeed predominant. Most workers (and most lenders and investors) do not know about cooperative organization, while selfemployment or small capitalist business is widely known and moderately well understood. For workers, the idea of cooperatives or other forms of worker ownership typically arises, when it does, only in extreme situations such as the threat of a plant closure. It is therefore to be expected that workers with an entrepreneurial frame of mind or a desire to be their own bosses turn to small business-over half a million such enterprises are started every year-even though the risk of failure is very high. 292 Not only need they not confront collective action problems - at least not on a scale or to the degree that they would in forming a cooperative-but they can operate within a familiar-and therefore attractive-organizational form.

\section{Collective Action Problems Without Taking Rational Choice Theory Too Far}

My public goods explanation of the rarity of cooperatives faces the following major problem: the classic versions of collective action problems, such as Olson's, depend on the egoistic assumptions of economic rationality that analyze even noneconomic motivations in "much the same way as monetary incentives." 293 But these assumptions, in their full-blown version, as used, for example, by Olson, are empirically indefensible. Common observation, noted by philosophers and social theorists for centuries and vindicated by modern cognitive psychology, strongly supports the proposition that people are not economically rational actors. ${ }^{294}$ We have seen that in special conditions, the sort of prisoner's dilemma of which the collective action problem is a generalization, can be constructed without these assumptions. ${ }^{295}$ These conditions are somewhat artificial, however, and it is highly doubtful that they can be effectively deployed to account for the rarity of cooperatives. So, if people are not egoistic "economically rational" agents, why think that Olson has given us the tools to explain this phenomenon?

The short answer is that Olson's collective action problem, with its underlying assumption of economic rationality, is right enough in the circumstances, as long as we retain appropriate modesty about the scope and ambitions of the theory, and in view of the range of alternative explanations as

292 See supra notes 269-70 and accompanying text (showing that the number of capitalist enterprise failures almost matches the number of startups, mostly small, every year).

293 OLSON, supra note 14, at 61.

${ }^{294}$ See, e.g., supra notes 202, 220, 225, 227 (discussing empirical tests of rational choice theory and the development of behavioral law and economics); supra note 263 (critiquing the assumption that moral behavior is reducible to rational self-interest).

295 See supra note 257. 
well as further historical and psychosociological evidence. This is not the place for an elaborate methodological discussion of idealization in social-scientific theories. However, an analogy may be helpful. The Debreu-Arrow model of the perfectly competitive market involves idealized counterfactual assumptions as well as omitting much that is important for some purposes. ${ }^{296} \mathrm{~A}$ richer and more realistic economic model may be necessary to explain much that concerns ussuch, perhaps, why there are any firms at all. ${ }^{297}$ But the idealization helps explain other things that matter, such as key effects of the operation of markets and the counterintuitive result that, in certain circumstances and up to a limit, Gordon Gekko was right that "greed is good." We do not have to go whole hog with Gary Becker ${ }^{298}$ and accept rational choice theory as a universal skeleton key to every social phenomenon to see that it has something to teach us about markets-or groups. ${ }^{299}$

296 See Arrow \& Debreu, supra note 6. The theorem assumes, for example, that there are no transactions costs. See supra note 6 (summarizing the theorem). The theorem is a formalization of Adam Smith's insight that every individual "intend[ing] only his own gain ... [is] led by an invisible hand to promote an end which was no part of his intention," "to render the annual revenue of the society as great as he can." 1 ADAM SMITH, AN INQUIRY into the Nature and Causes of the Wealth of Nations 456 (R.H. Campbell \& A.S. Skinner eds., Oxford Univ. Press 1976) (1776). Without having a glimmer of the theorem, no one knew better than Smith himself how much this was an idealization. He loaded his masterwork with warnings about the suspect motivations of businesspeople and their bad effect on society. See, e.g., id. at 267 ("The interest of the dealers, however, in any particular branch of trade or manufactures, is always in some respects different from, and even opposite to, that of the publick."). Nor did he deny altruistic motivations in asserting that while "man has almost constant occasion for the help of his brethren, ... it is in vain for him to [obtain] it from their benevolence only. He will be more likely to prevail if he can interest their self-love in his favour." Id. at 26 (emphasis added). Smith here does not deny our benevolent motivations, but merely says that they are insufficient by themselves to generate collective action. Smith wrote an entire treatise on the complexities of motivation, emphasizing sympathy and benevolence. See generally ADAM SMITH, THE THEORY OF MORAL SENTIMENTS (Arlington House 1969) (1759) [hereinafter SMITH, MORAL SENTIMENTS].

${ }^{297}$ See supra notes 99-100 and accompanying text (discussing Coase's account of the firm-market boundary-an issue ignored by Smith). Adding more realistic features, such as class conflict, see, e.g., MILL, supra note 4 , at 758 , a more plausible psychology than rational choice theory, see supra note 202, or indeed Olson's collective action problem, may help us understand why the beautiful Smithian world purportedly represented in the Debreau-Arrow model often produces counterintuitive and undesirable results, such as less productivity and more unpleasant work, Emest Mandel, Introduction to 1 MARX, CAPITAL, supra note 25 , at 35 . See generally Schwartz, supra note 2 (discussing why capitalist firms are not more participatory (citing Stephen Marglin, What Do Bosses Do? The Origins and Function of Hierarchy in Capitalist Production, 6 REV. RADICAL POL. ECON. 60 (1974) (using both class analysis and modem social psychology))).

${ }^{298}$ See generally GARY S. BECKER, THE ECONOMIC APPROACH TO HUMAN BEHAVIOR (1976) (arguing that rational choice theory explains all aspects of human behavior).

299 This is the course taken by Green \& Shapiro. GREEN \& SHAPIRO, supra note 202, at 202-03 (arguing that "abandon[ing] pure universalist ambitions for more subtle and modest 
Full-blooded rational choice theory or any strong theory committed to universal egoism is implausible. But commitment to the whole apparatus of rational choice theory, together with its claim of universal selfish maximization, is not required to explain why workers so rarely form cooperatives because of collective action problems. We need invoke no such strong reductionist claim about human motivation to support this explanation. As I articulate it, the account deploys the rational choice theoretical underpinnings of the collective action problem in the most modest and minimal way, not as a universal theory of human behavior, nor even as exhausting human motivation under market conditions. All that is necessary to add the rarity of cooperatives to the long list of public goods problems that characterize our society is the claim that, in market circumstances without further alteration in incentives or motivations, self-interest is likely to predominate enough over solidarity to inhibit the collective action necessary to create the public good of labor-managed enterprise unless special circumstances obtain.

Only an economist, perhaps, would deny what was obvious to Mill, that "the social feelings of mankind; the desire to be in unity with our fellowcreatures" is "a powerful principle in human nature." 300 However, as Hume insisted, "The qualities of the mind [include both] selfishness and limited generosity." 301 Hume - I think correctly--rejects the hypothesis of universal selfishness. ${ }^{302}$ " $[\mathrm{G}]$ enerosity and benevolence... sufficiently engage every

formulations [of rational choice theory] ... if a variant of [that] theory is to advance our understanding ... is essential").

300 JOHN STUART MILL, UTILITARIANISM (1863), reprinted in UTILITARIANISM AND OTHER WRITINGS, supra note 29, at 251, 284 (Mill was a distinguished "political economist" of his time.); see also ARISTOTLe, POLITICs 9 (H. Rackham trans., Harvard Univ. Press 1932) (" $[\mathrm{I}] \mathrm{t}$ is clear that the city-state is a natural growth, and that man is by nature a political [social] animal ...."); SMITH, MORAL SENTIMENTS, supra note 296.

${ }^{301}$ DaVID Hume, A Treatise OF Human Nature 494 (L.A. Selby-Bigge ed., Clarendon Press 1888) (1777); see also id. at 586 (stating similar). Lest I be charged with relying on the "unscientific" ruminations of mere philosophers (a distinction unknown in Hume's day), Hume's view is well-supported, if not universally accepted, in modern social psychology. See, e.g., C. Daniel Batson, Nadia Ahmad \& E.L. Stocks, Four Forms of Prosocial Motivation: Egoism, Altruism, Collectivism, and Principlism, in SoCIAL MOTIVATION 103, 113 (David Dunning ed., 2011) ("[T]heory and data now being advanced" based on "recent literature in sociology, economics, political science, and biology ... are more compatible [than the idea than altruistic behavior conceals hidden egoism] with the view that true altruism-acting with the goal of benefiting another-does exist and is part of human nature."). The authors of the article also survey empirical support for Mill's "social feeling" hypothesis, which they call "Collectivism: Benefit[ing] Another to Benefit a Group," id. at 116, and "Principlism: Benefit[ing] Another to Uphold a Moral Principle," id. at 117. While their language is awkward compared to Hume's and Smith's, they, like others, provide experimental data to support their conclusions.

302 DaVId Hume, AN ENQUiRy CONCERNING THE PRINCIPLes of Morals (1751), reprinted in ENQUIRIES CONCERNING THE HUMAN UNDERSTANDING AND CONCERNING THE PrINCIPLES OF MORALS 298 (L.A. Selby-Bigge ed., Clarendon Press 2d ed. 1963) (1777). He attributes this theory, so "contrary to common feeling," to a specious "love of simplicity 
heart . . .."303 Rebuking those who have "carried [selfishness] much too far,"304 Hume insists that "tis as rare to meet ... one, in whom all the kind affections, taken together, do not over-balance all the selfish." 305 While Hume thought that we are not monsters of selfish maximization, ${ }^{306}$ he held, nonetheless, that "each person loves himself better than any other single person." 307 Benevolence and generosity, while real, become attenuated with remoteness of connection and increase in distance. ${ }^{308}$ Little in the market tends to counteract this phenomenon. On the contrary, market incentives for individually self-interested action tend to exacerbate it. ${ }^{309}$

An Olsonian account of the rarity of labor management needs no more than this. The broadly Smithian or Humean account dovetails with Olson's theory of when collective action occurs, and is supported by the empirical facts in the few instances in which workers have overcome these difficulties, such as Mondragón, the plywood cooperatives, or the kibbutzim. Further, none of the other explanations that I have considered can meet the factual and logical challenges that confront them. I have surveyed only the most important and influential of the possible explanations, but with necessary changes, I believe that problems like the ones they face ${ }^{310}$ infect virtually all the competitor

which has been the source of much false reasoning in philosophy"-an observation that has lost none of its power in general, or aptness in the particular, context of the seductive appeal of economic rationality regarded as universal and sovereign. Id.; see also Lynne A. Stout, Taking Conscience Seriously, in MORAL MARKETS: ThE CRITICAL ROLE OF VALUES IN THE ECONOMY 157, 160 (Paul J. Zak ed., 2008) ("“[R]ational choice' dominates modern legal, business, and policy discussions... [in part because of] the relative simplicity and tractability of the Homo economicus account. Rational choice has flourished in part because academics find selfish behavior easy to predict and easy to model with a mathematical formula."). Simplicity is a virtue of scientific theories, but no less important are explanatory power, predictive accuracy, coherence with the rest of our knowledge, and a large number of other desiderata. See generally MILLER, supra note 203.

${ }^{303}$ HUME, supra note 302 , at 177 (section II, part I).

${ }^{304}$ HUME, supra note 301 , at 486 . Perhaps Hume here thinks of Hobbes.

$305 \mathrm{Id}$. at 487.

306 The term "monsters" is Hume's. See id. at 486.

${ }^{307} \mathrm{Id}$. at 487 . Hume need not make so strong a claim, nor need we; a statistically significant partiality for perceived self-interest suffices both for his purposes and mine.

$308 I d$. at 602 ("[T] he generosity of men is very limited, and . . . seldom extends beyond their friends and family, or, at most, beyond their native country."); see also id. at 487 (same). Beyond the obvious sociobiological explanations, recent research suggests that there may be a neurological basis for the attenuation of altruism over physical and relational distance. See Vani A. Mathur et al., Neural Basis of Extraordinary Empathy and Altruistic Motivation, 51 NEUROIMAGE 1468, 1472-74 (2010), available at http://culturalneuro.psych. northwestern.edu/MathurHaradaLipkeChiao_inpress.pdf.

${ }^{309}$ See MARX, MANIFESTO, reprinted in MARX-ENGELS READER, supra note 18, at 475 ("The bourgeoisie ... has left remaining no other nexus between man and man than naked self-interest, than callous 'cash payment."').

310 Most of Dow is devoted to detailed discussion of the inadequacies of a wide range of alternative explanations, although, as noted, Dow does not consider a collective action 
theories. The collective action theory I offer here avoids these problems, and, scaled to an appropriately modest level, accounts, fairly simply, for the observed phenomena in a way supported by empirical psychology. It should be supplemented by cross-cultural historical studies, based in realistic psychological theory.

\section{CONCLUSION}

It is a standing puzzle why modern market economies display the pattern of organizational forms that they do, in which capital-managed firms are overwhelmingly predominant. The puzzle derives from a pair of connected considerations. The first is Alchian's evolutionary hypothesis, that markets select enterprises that embody or adopt the more efficient of the range of features available, specifically the most productive and, presumably, profitable ones. The second is the striking fact that labor management has a significant productivity advantage over capital management. If productivity is a proxy for profitability and a measure of efficiency, the cooperative or labor-managed enterprise owned and operated by its employees should be a predominant form in a market economy, at least as or more important than the open corporation. John Stuart Mill, over a century and a half ago, predicted that this would be the direction in which the economy would evolve over time, partly for just these reasons. Mill was right about the reasons but wrong about the results. It would be a considerable exaggeration to say that the labor-managed firm is even marginal in the market today. ${ }^{311}$ Instead, the capital-managed firm, either the classic capitalist firm or the open corporation, is the near-universal form of enterprise organization. Why is that?

The standard accounts draw on variations of transactions cost theory, which calls attention to the "friction" involved in economic interactions. We surveyed three such representative accounts by leading analysts, and found each of them wanting logically and empirically. Two focused on purported inefficiencies internal to the enterprise. (1) Arnold attributed the rarity of labor management to inadequate internal monitoring that permitted shirking and opportunistic behavior by cooperative members. This account failed, first, because its central claim is untrue: labor management provides effective monitoring; second, because Arnold had no explanation of why this inefficiency would not be even worse in the open corporation, a vibrant organizational form; and third, because its central prediction, that labor-managed firms will be less productive, is confuted by the evidence. (2) Hansmann correctly rejected monitoring as a problem, and attempted to explain the puzzle in terms of the supposedly higher

explanation, and his own capital formation account will not hold water. See generally Dow, supra note 7.

311 If we concede Hansmann's claim that partnerships in professional services are labormanaged firms, see HANSMANN, ENTERPRISE, supra note 2, at 67, 70-71, we might diminish this characterization to a "great" overstatement, and qualify their marginality by sector. I have explained my skepticism above. See supra note 66. 
transaction costs of making management decisions, particularly about compensation, in enterprises with heterogeneous workforces. This account likewise lacked empirical support because, first, while compensation decisions are contentious, Hansmann treats the "homogeneity" (egalitarian pay and similarity of job function) that he regards as favorable to the success of producer cooperatives as something exogenous rather than as involving choices employee-owners might make about cooperative governance and enterprise operation; and second, because the most successful cooperative enterprise in the world, Mondragón, is highly heterogeneous, at least with respect to job function. Hansmann's attempt to remove Mondragón from the database turned on extremely implausible theories that presuppose unrestricted use of property and unmediated direct democracy that would apply with no less, and perhaps more, force to open corporations, striking them from the roster of privately owned, capitalistic enterprises. Finally, each of these theories put its explanation in the wrong place, failing to account for why so few cooperatives are started at all and instead predicting contrary to the evidence that, once started, they would suffer a higher failure rate than capitalist firms because of lower efficiency.

We then turned to (3) external transactions costs, in particular the problems that Dow claimed that workers would have raising sufficient external capital to start labor-managed firms. Dow showed at length, with a wealth of empirical detail, that labor management was as or more efficient than capital management. He located the problem I address in the Article at the right point; why, ab initio, do workers not form such enterprises? Dow put his finger on a puzzle in the empirical fact that most of the few such firms are indeed selffinanced, but he failed to explain, first, why investors and lenders would regard a more productive and efficient kind of enterprise as being abnormally risky; and second, why they would be biased against financing cooperatives, even if risky, in view of what might charitably be described as their very high tolerance of the risky, even reckless, behavior of capital-managed firms to whom they gladly hand over money; and, third, why workers did in fact lack the resources to finance even large scale cooperatives themselves in view of, inter alia, the proliferation of ESOPs, employee-owned but capital-managed enterprises.

I then proposed a novel account not developed elsewhere in the literature, that (1) labor management is a public good subject to the sort of collective action problem identified by Olson, and (2) the obstacles to the formation of which are amplified by the mere exposure or familiarity effect. In brief, goods that require a common contribution but from which no one can be excluded once they are provided will tend to be provided, if at all, in suboptimal amounts because each has a (selfish or "economically rational") incentive to contribute less than or none of the share required to generate the optimal amount of the good, on the pattern of an $n$-person prisoner's dilemma. This problem can be minimized with smaller groups where some individual has some (selfish or other) incentive to provide the public good as well as entrepreneurial vision and ability, and social pressure exists to cooperate. This fits the formation of Mondragón, for example, extremely well. Furthermore, the bare fact that labor 
management is rare makes it less attractive to workers and potential sources of finance because of the real, if arguably irrational, cognitive bias in favor of the familiar, including familiar organizational forms.

Collective action explanations are problematic because they depend, in standard presentations, on rational choice theory, according to which individuals are mere selfish maximizers. This is manifestly false. I argued that a more modest version of the theory would suffice to generate the problem in the appropriate circumstances if recast in Smithian and Humean terms that recognize our limited social and benevolent tendencies as well as our selfishness. The market, I urged, is paradigmatic of the circumstances where public goods problems arise. This, together with the preference for the familiar, combine to explain why there are so few cooperatives formed despite their productivity and other advantages.

If this is correct, where Mill went wrong was in supposing that marketsatomizing, individualizing, competitive institutions-could promote cooperation. Cooperatives may or may not do better in the market than capitalist enterprises once they are established, but the market will not grow cooperatives. Creating the public good of labor management requires going beyond the market and finding strong sources of institutional support, e.g., in the unions, a powerful political party, or the government, to provide financial, legislative, and other incentives or resources to implement it. For those who would like to see more cooperatives, indeed, an economy in which the labor-managed firm is predominant-and, to lay my cards on the table, I am one-this line of argument, if correct, points in a specific direction. That is an upside: the path is marked. The downside is that the path is steep.

The standard solution to a collective action problem is to find or create an institutional authority with the power to create the public good by changing the incentive structure. Traditionally, this was thought to require an authority with coercive power, typically the government. ${ }^{312}$ It is the role (and in some cases a justification) of the state to provide public goods that the market will not. ${ }^{313}$ However, if we accept that coercive power is key, state authority is not. Olson himself illustrates the idea through his discussion of the growth of the large U.S. labor union and its use of nonstate coercion to provide public goods of higher wages and better working conditions for its members. ${ }^{314}$ Moreover, institutions like political parties may lack formal coercive powers and still change incentive structures through their ability to offer or withhold rewards that are nonpublic goods. Further, it is unclear whether coercion or other negative incentives rather

312 See OLSON, supra note 14 , at $96,99$.

${ }^{313}$ Id. at $13-16,96-102$.

${ }^{314} \mathrm{Id}$. at 71 (citing Henry George and emphasizing the need for physical or moral coercion in labor organizing); see also William A. GAMSON, ThE STRATEGY OF Social PROTEST 82-88 (2d ed. 1990) (presenting evidence that social movements are more likely to succeed if they are willing to use some coercion). I underline that, on ethical and pragmatic grounds, I do not advocate unsanctioned coercion to promote social change in a democratic society. 
than rewards might be a more effective way to change the incentive structure. ${ }^{315}$ The carrot may be no less important than the stick. Governmental provision of resources that it would otherwise withhold for compliance with nonmandatory guidelines is a case in point. 316 The development of the ESOP through legislation that provided tax breaks and other advantages illustrates how this might work for labor-managed enterprise. ${ }^{317}$ There is a further question about whether changing incentives rather than other sorts of psychological and social influence are more effective ways of overcoming collective action problems. ${ }^{318}$ Other institutions, such as lobbying groups and other voluntary associations, including environmental organizations like the Sierra Club, may lack power to coerce or to provide significant rewards, but may exercise powerful normative force. ${ }^{319}$ How effective they are is a matter of debate.

It is not necessary here to take a position on any of these solutions. No doubt more than one would be necessary. The point is that promoting the increased formation and proliferation, much less the predominance of labormanaged enterprise, requires overcoming a collective goods problem by whatever means, whether they involve coercive or noncoercive governmental or private action, the activities of voluntary groups and associations with or without political power or coercive abilities of their own, for example by lobbying effectively for legislation that supports cooperatives that is at least as effective as that which supported ESOPs, or creating a bank like Mondragón's Caja together with publicity and training to further this end. These are daunting propositions. They are even more so when we realize that the development of any of these institutions itself involves at least one-and in many cases several- collective action problems of its own, because these are public goods themselves. But the creation of the ESOP, with all its limitations (involving noncoercive government action), or of Mondragón (involving idealistic private entrepreneurship), in both cases created under the conditions Olson identified as optimal for overcoming a collective action problem, offers some basis for optimism. If, however, this Article has assisted in the identification of the problem by answering in outline the question posed in the title, while diverting

315 Pamela Oliver, Rewards and Punishments as Selective Incentives for Collective Action: Theoretical Investigations, 85 AM. J. SoC. 1356, 1373 (1980) (discussing how negative incentives can ensure unanimity but undermine collective action if unanimity is not required).

316 See South Dakota v. Dole, 483 U.S. 203, 211-12 (1987) (upholding federal action in withholding federal highway funds from states that failed to impose an age limit of 21 on purchase of alcoholic beverages).

317 See supra note 58.

318 George W. Dent, Jr., Race, Trust, Altruism, and Reciprocity, 39 U. RICH. L. REV. 1001, 1012 (2005) ("Material incentives can even backfire. A person inclined to act out of altruism may come to view the act in terms of self-interest if offered a reward for so doing."). Ellickson's subtle account of "how neighbors solve problems" depends as much on shared norms of reciprocity and fairness as it does on implied or actual nonstate coercion. See generally ELLICKSON, supra note 260.

${ }^{319}$ HARDIN, supra note 14 , at 101-24. 
us from the dead ends of the usual answers, I have achieved my purpose and put us at the start of the right road. Further articulation of how to build the road as we travel is a task for another time. 
